\title{
LA TUTELA JURÍDICA DEL PAISAJE EN EL DÉCIMO ANIVERSARIO DE LA RATIFICACIÓN ESPAÑOLA DEL CONVENIO EUROPEO DEL PAISAJE. ESPECIAL REFERENCIA A LA INTEGRACIÓN DE PRESCRIPCIONES PAISAJÍSTICAS EN EL DERECHO URBANÍSTICO ${ }^{1}$
}

\author{
JUDITH GIFREU FONT \\ Profesora titular de Derecho Administrativo \\ Universitat Autònoma de Barcelona \\ judith.gifreu@uab.cat
}

Recibido: 25/06/2017 Aceptado: 06/10/2017

RESUMEN: Por su extraordinaria riqueza y variedad, el paisaje (ya resulte de la interacción del hombre con la naturaleza o no) es considerado un valor patrimonial y un recurso cada vez más apreciado por las políticas sectoriales con incidencia territorial. En cuanto espacio percibido y vivido, el paisaje nos revela la realidad cambiante y dinámica fruto de las alteraciones producidas con el paso del tiempo. $\mathrm{Y}$, sin duda, uno de los factores que inciden en esa transformación es la ordenación urbanística. Con dicho fundamento, y de la mano del Convenio Europeo del Paisaje de 2000 —ratificado por España el 26 de noviembre de 2007 y en vigor desde el 1 de marzo de 2008-, este trabajo da cuenta de la penetración en España de la noción del paisaje como punto de partida para el análisis de las técnicas e instrumentos de protección, gestión y ordenación del paisaje contemplados por la legislación urbanística, cada vez más implicada en ofrecer una ordenación y un diseño del paisaje que permitan integrar de forma apropiada los elementos naturales con los incorporados por la propia planificación urbanística a fin de lograr un paisaje inclusivo, armónico y de calidad.

\footnotetext{
${ }^{1}$ Este trabajo ha sido realizado en el marco del proyecto de investigación financiado por el Ministerio de Economía y Competitividad "Constitución climática global: gobernanza y Derecho en un contexto complejo" DER2016-80011-P.
} 
RESUM: Per la seva extraordinària riquesa i varietat, el paisatge (ja resulti de la interacció de l'home amb la naturalesa o no) és considerat un valor patrimonial i un recurs cada vegada més apreciat per les polítiques sectorials amb incidència territorial. En la seva condició d'espai percebut i viscut, el paisatge ens revela la realitat canviant i dinàmica, fruit de les alteracions produïdes amb el pas del temps. I, sens dubte, un dels factors que incideixen en aquesta transformació és l'ordenació urbanística. Amb aquest fonament, i de la mà del Conveni Europeu de Paisatge del 2000 -ratificat per Espanya el 26 de novembre del 2007 i en vigor des de l'1 de març del 2008-, aquest treball es fixa en la penetració a Espanya de la noció del paisatge com a punt de partida per a l'anàlisi de les tècniques i instruments de protecció, gestió i ordenació del paisatge contemplats per la legislació urbanística, cada vegada més implicada a proveir una ordenació i un disseny del paisatge que permetin integrar de forma apropiada els elements naturals amb els incorporats per la pròpia planificació urbanística a fi d'aconseguir un paisatge inclusiu, harmònic i de qualitat.

ABSTRACT: Because of its extraordinary richness and variety, the landscape (whether resulting from the interaction of man with nature or not) is considered a patrimonial value and a resource increasingly appreciated by sectoral policies with territorial incidence. As a perceived and lived space, the landscape reveals the changing and dynamic reality, the result of the changes produced over time. And, undoubtedly, one of the factors that influence this transformation is urban planning. On the basis of the European Landscape Convention of 2000 -ratified by Spain on 26 November 2007 and in force since 1 March 2008- this paper gives an account of the introduction of the concept of the landscape in Spain as a starting point for the analysis of the techniques and instruments of protection, planning and landscape management provided by urban legislation, increasingly involved in providing both landscape management and design that foster the integration of natural elements with those incorporated by urban planning itself in order to achieve an inclusive, balanced and quality landscape. 
PALABRAS CLAVE: paisaje - patrimonio cultural - urbanismo - desarrollo urbanístico sostenible.

PARAULES CLAU: paisatge - patrimoni cultural - urbanisme desenvolupament urbanístic sostenible.

KEYWORDS: landscape - cultural heritage - urban law - sustainable urban development.

SUMARIO: I. La identificación del paisaje como objeto de regulación legal. II. El patrimonio paisajístico: un ejemplo de integración natural y cultural. 1. La regulación del patrimonio protegido en España: patrimonio cultural frente a patrimonio natural. 2. El encaje de la noción de paisaje en el género patrimonial: el paisaje cultural como tipología especial del patrimonio cultural inmueble. III. El marco jurídico regulador del paisaje en España. Contextualización general. 1. El Convenio Europeo del Paisaje como norma clave de referencia. 2. La inexistencia de normativa estatal específica sobre paisaje. La protección del paisaje a través de múltiples normas sectoriales. 3. El diseño de estrategias de paisaje en la legislación autonómica; en especial, el marco jurídico de protección, gestión y ordenación del paisaje en Cataluña. a) Estado de la cuestión. b) La Ley catalana en materia de paisaje: normativa vigente y perspectivas de futuro. i. La Ley 8/2005, de 8 de junio, de protección, gestión y ordenación del paisaje. ii. El Anteproyecto de Ley del Territorio de Cataluña: ¿el fin de la emancipación normativa del paisaje? IV. La dimensión urbanística del paisaje. 1. La protección urbanística de los valores estéticos y culturales del paisaje en la primigenia normativa urbanística. 2. De la protección a la ordenación y gestión del paisaje. 3. Instrumentos urbanísticos para la protección y ordenación del paisaje. a) Breve mención al planeamiento territorial. b) Referencias al paisaje en la legislación de suelo estatal. c) Las determinaciones legales substantivas de aplicación directa y las directrices para el planeamiento urbanístico. d) Las determinaciones de los instrumentos de planeamiento urbanístico. e) Los catálogos de protección. f) Régimen de intervención urbanística en el suelo no urbanizable. V. Para concluir: la valorización del paisaje y de los bienes que son parte integrante de este. VI. Bibliografía. 


\section{La identificación del paisaje como objeto de regulación legal}

El paisaje forma parte del imaginario colectivo desde siempre. Cada individuo atesora unos recuerdos vivenciales que le vinculan indefectiblemente a los paisajes de la memoria, a los escenarios por los que discurre su existencia vital. Estos reductos identitarios nos conectan con nuestro yo íntimo, con la percepción de nuestra existencia, al tiempo que nos permiten adivinarnos como parte integrante de un todo, de una comunidad, puesto que son también espacios y realidades compartidos por los miembros que conforman esa colectividad $^{2}$. El paisaje es un "[p]roducto del tiempo, revela lo que somos, nuestro propio sentido, por lo que constituye un legado cultural, un patrimonio vivo y frágil, un testigo delicado envuelto en el trasiego del territorio"3. No es de extrañar que el arte, en sus múltiples facetas, haya buscado la sublimación estética del paisaje como medio de expresión de todo tipo de emociones y sentimientos; baste evocar, para constatar la evidencia de lo que se afirma, la fuerza que emana de la obra pictórica de artistas consagrados al paisaje como Constable, Turner, la escuela de Barbizon o los impresionistas franceses, por citar solo unos pocos ejemplos. También el paisaje ha dado nombre a una profesión, la de paisajista, cuyo cometido consiste en planificar y diseñar paisajes urbanos y rurales con criterios estéticos y funcionales tomando en consideración las características naturales y los valores históricos y culturales concurrentes en el lugar ${ }^{4}$. $Y$, pese a su relevancia e interés - no solo a efectos culturales y sociológicos, sino también como criterio y objetivo de ordenación territorial-, el paisaje ha recibido escasa atención por parte de la normativa interna y, hasta fechas muy recientes, no ha tenido el reconocimiento legal que se merece ${ }^{5}$.

\footnotetext{
${ }^{2}$ NARANJO, F., "El paisaje, ideas para la actuación", Martínez de Pisón, E. (dir.), Estudios sobre el paisaje, UAM - Fundación Duques de Soria, Murcia, 2000, p. 293 y ss. En el mismo sentido, SANZ HERRÁIZ, C., "Paisaje y patrimonio natural y cultural: historia y retos actuales", Nimbus, núm. 29-30, 2012, p. 688.

${ }^{3}$ SABALZA HERNÁEZ, A., La consagración jurídica del paisaje a través del Convenio Europeo del Paisaje, IVAP, Oñati, 2008, p. 23.

${ }^{4}$ Vid., al respecto, ASCÓN BORRÀS, R. et al., "La formación de expertos en gestión del paisaje", Busquets, J. y Cortina, A., Gestión del paisaje, Ariel, Barcelona, 2009, pp. 461-472.

5 De la misma opinión es CARBALLEIRA RIVERA, M. T., "El paisaje como bien cultural", Fernández Torres, J. R, Prieto de Pedro, J. y Trayter Jiménez, J. M. (coords.), El camino de Santiago y otros itinerarios. Cultura, historia, patrimonio, urbanismo, turismo, ocio y medio
} 
En España son diversas las leyes que han contemplado el paisaje como objeto de regulación (espacios naturales protegidos, urbanismo, patrimonio cultural), pero el tratamiento jurídico de esta figura ha sido parco y, hasta la recepción del Convenio Europeo del Paisaje de 2000, se ha movido exclusivamente en una dinámica de signo proteccionista. En el Convenio se reconoce el valor del paisaje como expresión de la diversidad del patrimonio común cultural y natural de la humanidad y como fundamento de su identidad, y se pone de relieve la necesidad de integrar este elemento en las políticas nacionales desde una óptica más dinámica que incluya la ordenación y gestión de dichos espacios.

El significativo desarrollo urbanístico y económico acontecido en España en las últimas décadas, que ha ido acompañado de un importante proceso de ocupación del suelo y de degradación ambiental, ha puesto en el punto de mira el proceso de degeneración de muchos de nuestros paisajes, así como el impacto sobre los valores ambientales, culturales, sociales..., que este paisaje posee. Frente a esta situación, en los últimos años ha empezado a ganar peso la consideración espacial del paisaje, emergiendo con fuerza la necesidad de articular mecanismos de protección, ordenación y gestión de este en cuanto bien de interés público. El paisaje va apareciendo, así, progresivamente como una responsabilidad que deben asumir los poderes públicos, además de como un derecho subjetivo ( $y$, correlativamente, un deber) de todas las personas ${ }^{6}$. Esta situación ha tenido también un claro reflejo normativo. Frente a las menciones al paisaje que se venían incluyendo en numerosas leyes sectoriales, de forma claramente sectorializada e insuficiente, desde hace unos años se está planteando la necesidad y conveniencia de adoptar instrumentos normativos que, teniendo como objetivo específico la protección del paisaje, atiendan a una ordenación integrada de este, articulando asimismo mecanismos de gestión y planificación. Se trata, en definitiva, de instrumentar una protección singularizada del paisaje, de forma que se supere la concepción transversal de

ambiente. Liber Amicorum Enrique Gómez-Reino Carnota, Tirant lo Blanch-Escola Galega de Administración Pública, Valencia, 2014.

${ }^{6}$ Es paradigmático en este sentido el Estatuto de Autonomía de Cataluña de 2006, cuyo artículo 27.1 establece lo siguiente: "Todas las personas tienen derecho a vivir en un medio equilibrado, sostenible y respetuoso hacia la salud, de acuerdo con los estándares y los niveles de protección que determinan las leyes. Tienen también derecho a gozar de los recursos naturales y del paisaje en condiciones de igualdad $y$ tienen el deber de hacer un uso responsable de los mismos y evitar su despilfarro". 
este objetivo que se encontraba presente en nuestro ordenamiento jurídico ${ }^{7}$. En esta línea se sitúan algunas comunidades autónomas que, como veremos más adelante, han acometido a través de leyes específicas una regulación integral del paisaje ${ }^{8}$.

Según el Diccionario de la Real Academia, el paisaje es la "extensión de terreno que se ve desde un sitio". Se trata de un componente esencial del elenco de bienes que integran el patrimonio natural y cultural, a la vez que constituye una pieza clave de la ordenación del territorio y del urbanismo. En la medida en que es parte de ese territorio plural y heteromórfico, el paisaje evidencia las tensiones existentes entre las exigencias del desarrollo urbanístico y económico y la necesidad de mantener unos estándares de protección medioambiental, tensiones que el principio de desarrollo sostenible intenta relajar. Como es de sobras conocido, este principio trae causa de una extensa nómina de declaraciones y propuestas internacionales y comunitarias, como el Informe Brundtland (1987), la Declaración de Rio (1992), las estrategias ambientales de la Unión Europea (Goteborg, 2001) y de la OCDE (2001), el Protocolo de Kioto (en vigor desde 2005), la Carta de Leipzig sobre Ciudades Europeas Sostenibles (2007) y el Marco Europeo de Referencia para la Ciudad Sostenible (Marsella, 2008), habiéndose consagrado en la actualidad como un objetivo imprescindible de la planificación urbana del siglo XXI, junto con los principios complementarios de cautela y acción preventiva y de prevalencia de la protección ambiental sobre la ordenación territorial y urbanística $^{9}$. La reorientación regulatoria del suelo se vislumbra claramente en

\footnotetext{
${ }^{7}$ PAREJA LOZANO, C., "Instrumentos legales para la ordenación del paisaje", El paisaje y la gestión del territorio. Criterios paisajísticos en la ordenación del territorio y el urbanismo, Diputación de Barcelona, Barcelona, 2006, p. 394.

${ }^{8}$ Sobre los aspectos urbanísticos de este trabajo, vid. in totum GIFREU FONT, J., L'ordenació urbanística a Catalunya, Marcial Pons, Madrid, 2012.

${ }^{9}$ La literatura jurídica relativa al principio de desarrollo sostenible es muy abundante. A título ejemplificativo, pueden citarse las siguientes obras: BARRERO RODRÍGUEZ, C., Urbanismo, Medio Ambiente y Patrimonio Histórico. El Medio Ambiente Urbano, Centro de Estudios Municipales y de Cooperación Internacional, Granada, 2003; BASSOLS COMA, M., "Urbanismo y Medio Ambiente", Rodríguez Ramos, L. (coord.), Derecho y Medio Ambiente, CEOTMA, Serie Monografías, núm. 4, Madrid, 1981; y, del mismo autor, "La Planificación Urbanística: su contribución a la protección del Medio Ambiente", Esteve Pardo, J. (coord.), Derecho del Medio Ambiente y Administración Local, Civitas, Madrid, 1996; CARRILLO BENITO, E. y CUERDA GARCíA-JUNQUEDA, J. C., Ciudad, Cambio Climático y Sostenibilidad, Junta de Andalucía, 2008; CELMA CELMA, J., "Pautas para la sostenibilidad en las ciudades", Gestión ambiental, núm. 3, 1999; DAL PIAZ, A. y FORTE, F., Pianificazione urbanística ed ambientale, Maggioli Editori, Rimini, 1999; FARINÓS DASÍ, J. y ROMERO GONZÁLEZ, J. (coords.), Territorialidad y buen gobierno para el desarrollo sostenible: nuevos
} 
la exposición de motivos de la Ley 8/2007, de 28 de mayo, de Suelo, que se desvincula de la finalidad desarrollista que había dominado la historia del urbanismo español contemporáneo y aboga por acomodarse a los requerimientos de un desarrollo sostenible, minimizando el impacto del crecimiento urbano y apostando por la regeneración de la ciudad existente. Un Estado social y democrático de derecho exige que el diseño de las políticas territoriales y urbanísticas tenga en cuenta valores de justicia social y de mejora ambiental que no resulten condicionados por los poderes económicos. Por lo tanto, la decisión sobre la utilización del suelo, en cuanto recurso natural escaso y patrimonio común de la sociedad, no puede quedar al arbitrio de intereses particulares ${ }^{10}$. La doctrina constitucional ha puesto de manifiesto el

principios y nuevas políticas en el espacio europeo, Universidad de Valencia, 2007; FERNÁNDEZ DE GATTA SÁNCHEZ, D., "La política ambiental y sobre el desarrollo sostenible de la Unión Europea: de sus orígenes a la Estrategia de Lisboa", Revista Aranzadi de Derecho Ambiental, núm. 13, 2008; FOLCH, R., "La aproximación sostenibilista", Folch, R. (coord.), El Territorio como Sistema. Conceptos y Herramientas de Ordenación, Diputación de Barcelona, Barcelona, 2003; DE FORN FOXÀ, M., Estratègies i territoris, els nous paradigmes, Diputació de Barcelona, Barcelona, 2004; GEHRING, M., "Sustainable development in World Trade Law: perspectives, process and prospects", Bugge, H. C. y Voigt, C. (eds.), Sustainable Development in National and International Law, Europa Law Publishing, 2008; GIRARDET, H., Creando ciudades sostenibles, Tilde, Valencia, 2001; LOPERENA ROTA, D., Desarrollo sostenible y globalización, Aranzadi, Navarra, 2003; LORA-TAMAYO VALLVÉ, M., Derecho urbanístico y medio ambiente. Hacia el desarrollo urbano sostenible, Dykinson, Madrid, 2006; MARESCA CABOT, J. C., "Los principios del Derecho Urbanístico. En especial el Desarrollo Urbanístico Sostenible", Trayter, J. M. (coord.), El Ordenamiento Urbanístico de Cataluña, Aranzadi, Barcelona, 2005; MARINERO PERAL, Á., El Urbanismo como instrumento para la gestión del desarrollo sostenible. Medio Ambiente y Desarrollo Sostenible, Junta de Castilla y León-CUNAL, 2001; MENÉNDEZ REXACH, Á., "Urbanismo sostenible, clasificación del suelo y criterios indemnizatorios: estado de la cuestión y algunas propuestas", Revista de Derecho Urbanístico y Medio Ambiente, núm. 200, 2003; DECLERIS, M., The law of sustainable development. General principles, Oficina de Publicaciones Oficiales de las Comunidades Europeas, Luxemburgo, 2000; MONTINNI, M., "Sustainable development within the climate change regime", Bugge, H. C. y Voigt, C. (eds.), Sustainable Development in National and International Law, Europa Law Publishing, 2008; MONTORO CHINER, M. J., "El urbanismo del desarrollo sostenible", Trayter, J. M. (dir.), Estudios jurídicos sobre urbanismo. Una reflexión prospectiva, Cedecs, Barcelona, 1998; PAREJO NAVAS, T., La Estrategia Territorial Europea. La percepción comunitaria del uso del territorio, Marcial Pons, Madrid, 2004; PIÑAR MAÑAS, J. L., "El desarrollo sostenible como principio jurídico", AA. VV., Desarrollo sostenible y protección del medio ambiente, Civitas, Madrid, 2002; VAQUER CABALLERÍA, M., "Constitución, ley de suelo y ordenamiento territorial y urbanístico", Revista General de Derecho Administrativo, núm. 15, 2007.

${ }^{10}$ La STS de 14 de octubre de 2008 señala que "desde una perspectiva urbanística y medioambiental la defensa jurídica de los suelos rústicos de especial protección se nos presenta hoy -en el marco de la amplia, reciente y variada normativa sobre la materia, en gran medida fruto de la transposición de las normas de la Unión Europea- como un reto ciertamente significativo y como uno de los aspectos más sensibles y prioritarios de la expresada y novedosa normativa. Ya en el Apartado I de la Exposición de Motivos de la Ley 8/2007, de 28 de mayo, de Suelo (hoy Texto Refundido de la misma, aprobado por Real Decreto Legislativo 2/2008, de 20 de junio) se apela en el marco de la Constitución Española - para justificar el nuevo contenido y dimensión legal— al 'bloque normativo ambiental formado 
"carácter complejo y polifacético que tienen las cuestiones relativas al medio ambiente [...], [en consecuencia,] el medio ambiente da lugar a unas competencias, tanto estatales como autonómicas, con un carácter metafóricamente 'transversal' por incidir en otras materias incluidas también, cada una a su manera, en el esquema constitucional de competencias [...]. Es claro que la transversalidad predicada no puede justificar su 'vis expansiva', ya que en esta materia no se encuadra cualquier tipo de actividad relativa a esos recursos naturales, sino sólo la que directamente tienda a su preservación, conservación o mejora". Esa misma doctrina ha establecido que las personas tienen el derecho de disfrutar y el deber de conservar el medio ambiente, mientras que a los poderes públicos se les impone el mandato de protegerlo (STC 102/1995, de 26 de junio). De ello se desprende que los poderes públicos han de velar por la utilización racional del territorio y del medio ambiente, favoreciendo o conteniendo, según corresponda, los procesos de transformación y ocupación del suelo, compatibilizando el crecimiento y el dinamismo económicos con los imperativos de desarrollo sostenible y la mejora de la calidad de vida de los ciudadanos. Y en esta convergencia de caminos entre la explotación del territorio y su protección, el paisaje (en cuanto elemento

por sus artículos 45 a 47', de donde deduce 'que las diversas competencias concurrentes en la materia deben contribuir de manera leal a la política de utilización racional de los recursos naturales y culturales, en particular el territorio, el suelo y el patrimonio urbano y arquitectónico, que son el soporte, objeto y escenario de aquéllas al servicio de la calidad de vida' [...]. Pues bien, desde tal consideración, y teniendo en cuenta el principio de desarrollo territorial y urbano sostenible (artículo 2 del citado Texto refundido), los nuevos derechos de los ciudadanos en la materia (artículo 4) y los deberes de los mismos (artículo 5), el actual contenido del derecho de propiedad (artículo 9), así como el régimen de utilización del suelo rural (artículo 13), debemos llegar a la conclusión de que actuaciones como la de autos — desde la perspectiva cautelar desde la que ahora la analizamos - suponen una 'perturbación grave de los intereses generales' y, en consecuencia, justifican plenamente la denegación de la medida cautelar pretendida. Es, sin duda, la expresada proyección normativa la que nos mueve a tal consideración, en un supuesto como el de autos - recordamos- consistente en la edificación de una nave industrial, llevada a cabo en un suelo rústico de protección forestal y de protección de espacios naturales y sin licencia o autorización alguna suficiente local o autonómica.

Desde esta perspectiva, pues, relativa a la prevalencia de los intereses generales (que se concentran en la protección medioambiental expresada) frente a los intereses particulares o intereses de terceros que se invocan, la valoración efectuada por la Sala de instancia se nos presenta como sólida jurídicamente e impecable en su argumentación. Efectivamente, teniendo en cuenta la situación que describimos, la Sala de instancia ha llevado a cabo una adecuada ponderación de los intereses en conflicto, resultando razonable la protección del interés general expuesto frente a los particulares, económicos y —en su caso- resarcibles de la recurrente. Ratificando tal ponderación de los intereses en conflicto, que se esgrimen y defienden en el recurso, consideramos más atendible la protección de la zona de referencia que el mantenimiento de la nave levantada, razón por la que es nuestro parecer que el Tribunal a quo no ha vulnerado lo dispuesto por el artículo 130.2 de la Ley Jurisdiccional (ni en el 130.1) al denegar la medida cautelar suspensiva interesada". 
integrante del concepto jurídico indeterminado "medio ambiente") se nos muestra como uno de los aspectos que ineludiblemente deben ser objeto de tratamiento legal con el fin de incorporar objetivos de sostenibilidad que permitan mantener la capacidad productiva del territorio sin que ello vaya en detrimento de la calidad ambiental y de la preservación y mejora del paisaje.

\section{El patrimonio paisajístico: un ejemplo de integración natural y cultural}

\section{La regulación del patrimonio protegido en España: patrimonio cultural} frente a patrimonio natural

España ocupa el tercer lugar en el ranking de países del mundo con mayor número de bienes y sitios declarados por la Unesco como Patrimonio de la Humanidad, a escasa distancia de los dos países situados a la cabeza, Italia y China. Esta circunstancia es un claro indicio de la riqueza cultural del país, entre la que se cuentan tanto edificios monumentales, cascos históricos y conjuntos arquitectónicos como paisajes, parques naturales y también tradiciones que se mantienen vivas y arraigadas en los grupos y comunidades que integran nuestra sociedad. Se trata de un conjunto de bienes susceptibles de ser apreciados en sí mismos, con independencia de su titularidad, naturaleza o valor económico, cuya importancia y función social han sido cuidadosamente analizadas por la doctrina iusadministrativa ${ }^{11}$.

\footnotetext{
${ }^{11}$ Sin ánimo de exhaustividad, puede consultarse, en materia de patrimonio cultural, la bibliografía siguiente: ALEGRE ÁVILA, J. M., Evolución y régimen jurídico del Patrimonio Histórico: la configuración dogmática de la propiedad histórica en la Ley 16/1985, de 25 de junio, del Patrimonio Histórico Español, Ministerio de Cultura, Secretaría General Técnica, Madrid, 1994; ABAD LICERAS, J. M., "La distribución de competencias entre el Estado y las Comunidades Autónomas en materia de patrimonio histórico-artístico: soluciones doctrinales", Revista Española de Derecho Constitucional, núm. 55, 1999; ALONSO IBÁÑEZ, M. R., El Patrimonio Histórico: destino público y valor cultural, Servicio de Publicaciones de la Facultad de Derecho de la Universidad, Oviedo, 1992; ÁLVAREZ GONZÁLEZ, E. M., La protección jurídica del patrimonio cultural subacuático en España, Tirant lo Blanch, Valencia, 2012; ANGUITA VILLANUEVA, L. A., Derecho de propiedad privada en los bienes de interés cultural, Dykinson, Madrid, 2001; BASSOLS COMA, M., "Los Conjuntos Históricos: su concepto en el ordenamiento jurídico español e internacional", Patrimonio Cultural y Derecho, núm. 4, 2000; BARRERO RODRÍGUEZ, C., La ordenación jurídica del patrimonio histórico, Civitas, Madrid, 1990; y, de la misma autora, La ordenación urbanística de los conjuntos históricos, lustel, Madrid, 2006; MARTíN-RETORTILLO BAQUER, L., "Nuevas perspectivas en la conservación del patrimonio histórico: una recapitulación global", Revista Aragonesa de Administración
} 
Como apunta la STC 17/1991, de 31 de enero, este patrimonio objeto de protección legal está configurado por "unos determinados bienes que, por estar dotados de singulares características, resultan portadores de unos valores que les hacen acreedores de una especial consideración y protección, en cuanto dichos valores, y hasta los mismos bienes son patrimonio cultural de todos los españoles e incluso de la comunidad internacional por constituir una aportación histórica a la cultura universal". Por ello, la Administración debe adoptar las medidas necesarias para asegurar la conservación de todo este patrimonio, promover su enriquecimiento y fomentar y tutelar el uso y disfrute de los bienes que lo integran por todos los ciudadanos como una forma de acceso a la cultura.

España dispone de una legislación que busca asegurar la protección y fomentar nuestro vasto patrimonio, el cual, lo mismo que en el resto de países europeos, se ha ido ampliando conceptualmente para incorporar tanto lo monumental y artístico como lo natural, sin excluir las manifestaciones culturales vivas asociadas a significados colectivos compartidos y plenamente arraigadas en la sociedad. Por influencia de la Convención sobre la Protección del Patrimonio Mundial, Cultural y Natural, aprobada en 1972 por la Conferencia General de la ONU por la Educación, la Ciencia y la Cultura, este patrimonio engloba tanto el de índole cultural, asociado tradicionalmente al patrimonio histórico-arquitectónico, como el que tiene su origen en la naturaleza. En consecuencia, el documento internacional recoge una definición muy amplia del concepto de patrimonio, incluyendo no solo bienes muebles, edificios, monumentos, conjuntos arquitectónicos urbanos y yacimientos arqueológicos, sino también parques y jardines y fincas rústicas, entre otros. Los artículos 1 y 2 de dicho texto contienen una definición de ambos, aunque debe señalarse que, a pesar de la distinción legal, es evidente que el

Pública, núm. 19, 2001; PÉREZ DE ARMIÑÁN Y DE LA SERNA, A., Las competencias del Estado sobre el Patrimonio Histórico Español en la Constitución de 1978, Civitas, Madrid, 1997; VAQUER CABALLERÍA, M., Estado y cultura: la función cultural de los poderes públicos en la Constitución Española, Centro de Estudios Ramón Areces, Madrid, 1998; y WACKERNAGEL, M. y REES, W., Our Ecological Footprint. Reducing human impact on Earth, Grabiola Island, New Society Publishers, 1996. 
patrimonio natural comparte también esa significación cultural ${ }^{12}$. Así, el patrimonio cultural está compuesto por monumentos (obras arquitectónicas, de escultura o de pintura monumentales, elementos o estructuras de carácter arqueológico, inscripciones, cavernas y grupos de elementos que tengan un valor universal excepcional desde el punto de vista de la historia, del arte o de la ciencia), conjuntos (grupos de construcciones, aisladas o reunidas, cuya arquitectura, unidad e integración en el paisaje les confiere un valor universal excepcional desde esos mismos puntos de vista que hemos apuntado anteriormente) y lugares (obras del hombre $u$ obras conjuntas del hombre y la naturaleza, incluidos los lugares arqueológicos que tengan un valor universal excepcional desde el punto de vista histórico, estético, etnológico o antropológico). En cuanto al patrimonio natural, lo conforman los monumentos naturales constituidos por formaciones físicas y biológicas o por grupos de esas formaciones que tengan un valor universal excepcional desde el punto de vista estético o científico; las formaciones geológicas y fisiográficas y las zonas estrictamente delimitadas que constituyan el hábitat de especies, animales y vegetales, amenazadas, que tengan un valor universal excepcional desde el punto de vista estético o científico; y los lugares naturales o las zonas naturales estrictamente delimitadas que tengan un valor universal excepcional desde el punto de vista de la ciencia, de la conservación o de la belleza natural. En un contexto de globalización económica y cultural en el que las formas de vida y las costumbres tienden a mimetizarse cada vez más y en el que crece la preocupación por la conservación de los espacios naturales, amenazados por problemas ambientales ligados al cambio climático y al agotamiento de los recursos naturales, los bienes que integran el patrimonio cultural y natural son una muestra de identidad colectiva singular que garantiza la pervivencia de los trazos característicos del paisaje urbano y rural propios. Su protección, por lo tanto, es vital para poder transmitir este legado a las generaciones futuras.

\footnotetext{
${ }^{12}$ Esa dimensión cultural ha sido destacada por la doctrina: "Una figura patrimonial ha emergido con fuerza en el deseo de integrar los aspectos culturales y ecológicos en una misma finalidad y con el objetivo de implantar una nueva cultura de la ordenación territorial. Se trata del concepto de paisaje o, más concretamente, paisaje cultural, epíteto necesario para vincularlo al ámbito cultural pero en realidad redundante, pues todo paisaje incluye una actividad o mirada cultural sobre él". GONZÁLEZ-VARAS, I., Patrimonio cultural. Conceptos, debates y problemas, Cátedra, Madrid, 2015, p. 190.
} 
Ambos patrimonios, cultural y natural, han sido objeto de regulación por el Estado español a los efectos de garantizar su integridad y protección. En el primer caso, mediante la Ley 16/1985, de 25 de junio, del Patrimonio Histórico Español, y, en el segundo, mediante la Ley 42/2007, de 13 de diciembre, del Patrimonio Natural y de la Biodiversidad. A todo ello debe sumarse la normativa dictada por las comunidades autónomas en relación con los bienes protegidos situados en su ámbito territorial de competencia. Debe decirse que se echa en falta que las leyes estatales citadas no tengan vasos comunicantes - sería deseable que existieran paralelismos, al menos en el plano conceptual-, y, más concretamente, que no se aborde un tratamiento legal unitario del conjunto de categorías de bienes del patrimonio español ${ }^{13}$.

Una de las normativas con más solera es la relativa a la cultura material generada por la acción del hombre, prevista en la temprana Ley de 13 de mayo de 1933, que contenía la regulación concreta de los bienes que conforman el patrimonio histórico, cuya protección y enriquecimiento son objeto de diversas convenciones y recomendaciones internacionales suscritas por España. Esta norma fue reemplazada por la Ley 16/1985, de 25 de junio, del Patrimonio Histórico Español ${ }^{14}$, cuyo ámbito de aplicación ha quedado obsoleto por limitado ante los avances terminológicos referidos al patrimonio protegido teniendo en cuenta, además, que el adjetivo histórico es restrictivo y ha sido superado por la normativa autonómica, que coincide en el uso del término patrimonio cultural como concepto más inclusivo- ${ }^{15}$. Por este motivo, para completar la regulación de los bienes integrantes del patrimonio protegido debemos recurrir también a otras normas, como las que regulan el patrimonio natural y el patrimonio inmaterial. Con todo, la Ley del Patrimonio Histórico

\footnotetext{
${ }^{13}$ En un sentido similar, en los Estados Unidos se distingue entre los paisajes con valor histórico, regidos por la normativa de protección del patrimonio histórico, y aquellos que poseen un valor estético, cuya protección se remite a la normativa ambiental. BRONNIN, S., "Report for the United States", XI International Urban Law Congress, Architectural Heritage, Sites and Landscapes Seized by Urban Law, Barcelona, septiembre de 2017, p. 2.

${ }^{14}$ El desarrollo de los aspectos procesales y organizativos de la Ley 16/1985 se encuentra en el Real Decreto 111/1986, de 10 de enero, de desarrollo parcial de la Ley.

${ }^{15}$ Sobre la indeterminación del concepto de bien cultural y su influencia por los planteamientos de la doctrina italiana, vid. LÓPEZ RAMÓN, F., "Reflexiones sobre la indeterminación y amplitud del patrimonio cultural", Revista Aragonesa de Administración Pública, núm. 15, 1999, pp. 194-195. La Ley 7/1990, de 3 de julio, del Patrimonio Cultural Vasco, fue la primera norma autonómica que recurrió al calificativo cultural para referirse a su patrimonio.
} 
Español amplía notablemente, respecto de la normativa precedente de 1933, los bienes que lo integran. Conforman esta tipología los inmuebles y objetos muebles que tienen un interés artístico, histórico, paleontológico, arqueológico, etnográfico, científico o técnico. También forman parte de este el patrimonio documental y bibliográfico, los yacimientos y zonas arqueológicas, así como los sitios naturales, jardines y parques que tengan valor artístico, histórico o antropológico $^{16}$. Además, se integran en el patrimonio histórico español los bienes que forman parte del denominado "patrimonio cultural inmaterial", lo que permite incluir manifestaciones culturales menos tangibles y más abstractas como las formas de vida, las prácticas sociales y los conocimientos y técnicas que forman parte de nuestra comunidad. La Ley no recoge expresamente la noción de paisaje, aunque los sitios históricos —entendidos como los lugares o parajes naturales vinculados a acontecimientos o recuerdos del pasado, a tradiciones populares, creaciones culturales o de la naturaleza y a obras del hombre, que posean valor histórico, etnológico, paleontológico o antropológico (art. 15.4)— constituyen su referente más cercano.

En lo que respecta al patrimonio natural, su regulación es más reciente que la atinente al patrimonio arquitectónico, pero, aun así, puede considerarse temporalmente adelantada si se tiene en cuenta que las primeras manifestaciones relevantes en defensa del derecho a un medio ambiente de calidad que asegure la salud y el bienestar de los ciudadanos se producen en los Estados Unidos en la década de los setenta del siglo pasado. La primera norma que centra su atención en esta temática es la Ley 15/1975, de 2 de mayo, de Espacios Naturales Protegidos, dictada en el tardofranquismo y antes de que la Constitución de 1978 reconociera el derecho de todos los españoles

\footnotetext{
${ }^{16}$ Las medidas de protección y fomento que se despliegan en la Ley no tienen un carácter uniforme, puesto que se establecen distintos niveles de protección en función de la singular relevancia del bien. Estos regímenes de protección se vinculan a las distintas categorías legales existentes, que, en orden ascendente de protección, son las siguientes: patrimonio histórico español, bienes del Inventario General de Bienes Muebles y bienes de interés cultural. La primera constituye una categoría general y las restantes son categorías especiales que disfrutan de una protección cualificada. Téngase en cuenta, además, el régimen especial de los bienes inmuebles que forman el Patrimonio Nacional, un conjunto de sitios y palacios de titularidad del Estado que originariamente eran patrimonio de la Corona (El Escorial, El Pardo, La Zarzuela...) y que se rige por la Ley 23/1982, de 16 de junio. Estos bienes quedan afectos al uso y servicio del rey y de los miembros de la familia real para el ejercicio de la alta representación que la Constitución y las leyes les atribuyen.
} 
a disfrutar de un medio ambiente adecuado para el desarrollo de la persona e impusiera el deber de conservarlo, exigiendo a los poderes públicos que velen por la utilización racional de todos los recursos naturales con el fin de proteger y mejorar la calidad de vida y defender y restaurar el medio ambiente (art. 45 CE). La Ley de 1975 fue sustituida por la Ley 4/1989, de 27 de marzo, de Conservación de los Espacios Naturales y de la Flora y Fauna Silvestres, al amparo de la cual se ha ido dictando la normativa autonómica ${ }^{17}$. Esta disposición legal es la que introduce en España el régimen de conservación de la naturaleza desde una perspectiva integral e inclusiva sobre la base de los convenios multilaterales firmados por España en materia de protección de la naturaleza y de la recepción del derecho comunitario a través de la transposición al ordenamiento jurídico español de distintas directivas en la materia. En la actualidad, la norma vigente es la Ley 42/2007, de 13 de diciembre, del Patrimonio Natural y de la Biodiversidad, cuya finalidad es establecer el régimen jurídico básico de la conservación, uso sostenible, mejora y restauración del patrimonio natural, evitando la degradación de los espacios naturales y, muy especialmente, de los que revisten un mayor interés ${ }^{18}$. A estos efectos, el patrimonio natural se define como el "conjunto de bienes y recursos de la naturaleza fuente de diversidad biológica y geológica, que tienen un valor relevante medioambiental, paisajístico, científico o cultural" ${ }^{19}$. La Ley hace suya la definición de paisaje contenida en el Convenio Europeo del Paisaje de 2000

\footnotetext{
17 Vid. LÓPEZ RAMÓN, F., "La Ley de Conservación de 1989 y la continuidad de sus planteamientos en la Ley del Patrimonio Natural de 2007", Noticias de la Unión Europea, núm. 307, 2010 (Ejemplar dedicado a: Patrimonio natural y biodiversidad), pp. 3-8.

${ }_{18}$ Deben tenerse en cuenta, además, las normas y recomendaciones internacionales y europeas que velan por la planificación, protección y conservación del patrimonio natural y de la biodiversidad, como el Convenio sobre la Diversidad Biológica de 1992, la Directiva Hábitats de 1992, el Plan de Acción de la Cumbre Mundial de Desarrollo Sostenible de Johannesburgo de 2002 y el Programa de Trabajo sobre Áreas Protegidas de 2004, entre otros.

${ }^{19}$ El uso de este patrimonio natural se conecta a unos principios de actuación establecidos en su artículo 1, como son la prevalencia de la protección ambiental sobre la ordenación territorial y urbanística; la incorporación del principio de precaución en las intervenciones que afecten a los espacios naturales; la prevención de los problemas emergentes consecuencia del cambio climático, la mitigación y adaptación a este, así como la lucha contra sus efectos adversos; el impulso de procesos de mejora en la sostenibilidad del desarrollo asociados a espacios naturales o seminaturales protegidos; la promoción de la utilización ordenada de los recursos para garantizar el aprovechamiento sostenible del patrimonio natural; la participación de los habitantes y de los propietarios de los territorios incluidos en espacios protegidos en las actividades coherentes con la conservación del patrimonio natural y de la biodiversidad que se desarrollen en dichos espacios y en los beneficios que se deriven de ellas (custodia del territorio); y la integración de los requerimientos de conservación, uso sostenible, mejora y restauración del patrimonio natural y la biodiversidad en las políticas sectoriales.
} 
al referirse a los "paisajes protegidos", categoría que se desarrolla esencialmente mediante una serie de previsiones como el establecimiento de figuras generales y específicas para la protección del paisaje en los espacios naturales protegidos, la exigencia de que el análisis de los paisajes forme parte del contenido mínimo de los planes de ordenación de los recursos naturales, su utilización potencial como instrumento para dotar de coherencia y conectividad a la red Natura 2000 y el fomento de las actividades que contribuyen a su protección. Sin embargo, la Ley no ofrece una regulación completa de la protección del paisaje (en el sentido de legislación básica del artículo 149.1.23 $\mathrm{CE})$ y remite a una legislación futura — que a día de hoy no ha sido aprobadala implementación de instrumentos de gestión del paisaje como los previstos, con carácter de mínimos, en el Convenio Europeo del Paisaje ${ }^{20}$.

Por último, debe hacerse notar la creciente importancia que ha adquirido en España el patrimonio cultural inmaterial (conocimientos y tradiciones orales, usos y prácticas sociales, rituales, espectáculos...) desde su primera mención en la Ley del Patrimonio Histórico Español (bajo la rúbrica "Del Patrimonio Etnográfico). En el mencionado texto legal ya se vislumbra una vocación colectiva por mantener vivas estas manifestaciones culturales, a pesar de su vulnerabilidad y frágil supervivencia por efecto de los procesos de globalización y el desarrollo de las técnicas de comunicación que, sin prisa pero sin pausa, están homogeneizando las costumbres, los saberes y las tradiciones heredados de nuestros antepasados y diluyendo esas marcadas peculiaridades que durante siglos han permitido la coexistencia de una pluralidad de sociedades culturales dentro de ese gran magma social que es la comunidad mundial. Por influjo de la Convención para la Salvaguardia del Patrimonio Cultural Inmaterial (Unesco) de 2003 (ratificada por España en 2006), se aprobaron, en octubre de 2011, el Plan Nacional de Salvaguardia del Patrimonio Cultural Inmaterial para dar protección a esta manifestación del

\footnotetext{
${ }^{20}$ No pretende la Ley 42/2007, como se pone de manifiesto en su exposición de motivos, "ser el instrumento a través del cual se implantarán en España, de manera generalizada, las políticas de protección del paisaje como legislación básica del artículo 149.1.23, políticas cuyo contenido técnico y enfoque general, no exento de valor paradigmático, exigen la puesta en marcha de instrumentos de gestión como los establecidos, con carácter de mínimos, en el Convenio Europeo del Paisaje, hecho en Florencia el 20 de octubre del año 2000 , en el seno del Consejo de Europa y que serán introducidos en la política ambiental española en un momento posterior".
} 
patrimonio cultural y, posteriormente, la Ley 10/2015, de 26 de mayo, para la salvaguardia del Patrimonio Cultural Inmaterial. De conformidad con el artículo 2 de la Ley, son manifestaciones de este "capital simbólico" ${ }^{21}$, entre otras, las tradiciones y expresiones orales, incluidas las modalidades y particularidades lingüísticas como vehículo del patrimonio cultural inmaterial; la toponimia tradicional como instrumento para la concreción de la denominación geográfica de los territorios; las artes del espectáculo; los usos sociales, rituales y actos festivos; los conocimientos y usos relacionados con la naturaleza y el universo; las técnicas artesanales tradicionales; la gastronomía, elaboraciones culinarias y alimentación; y los aprovechamientos específicos de los paisajes naturales ${ }^{22}$.

\section{El encaje de la noción de paisaje en el género patrimonial: el paisaje cultural como tipología especial del patrimonio cultural inmueble}

Existe una cierta confusión respecto a la construcción conceptual del paisaje, ya que, por lo común, se tiende a identificarlo exclusivamente con la naturaleza, cuando es evidente que, atendiendo a su caracterización física, el paisaje aglutina entornos de muy distinta condición. Aunque es habitual que al hablar de paisaje nuestra mente vuele hacia parajes idílicos, esto es, espacios naturales y abiertos que se han mantenido ajenos a los procesos de artificialización y que no han sufrido otras modificaciones que las derivadas de los procesos naturales, lo cierto es que los entornos humanizados o urbanos también constituyen paisaje. La normativa aplicable no establece una distinción entre paisajes que son producto de las condiciones naturales del territorio y los que se derivan de la acción del ser humano, por lo que su identificación legal como bien integrante de un patrimonio de índole natural o bien cultural no está concretada legalmente. Esto no significa ni mucho menos que el paisaje deba ser una cosa o la otra, precisamente porque la singularidad del paisaje, sea

\footnotetext{
${ }^{21}$ VELASCO MAíLLO, H. M., "Patrimonio Cultural Inmaterial", Antigüedad del Castillo-Olivares, M. D. (dir.), Mediación y gestión del patrimonio en Europa, Editorial Universitaria Ramón Areces, Madrid, 2012, p. 72.

${ }^{22}$ Recientemente, en abril de 2017, el Consejo de Ministros aprobó la declaración de la "Semana Santa", "El Carnaval" y "La Trashumancia" como manifestación representativa de patrimonio cultural inmaterial, en lo que constituye la primera declaración de esta índole en aplicación de la Ley 10/2015.
} 
urbano o natural, viene dada en parte o en su totalidad por sus valores culturales $^{23}$.

El paisaje natural y el paisaje urbano no se rigen por un marco legal común, circunstancia que contribuye a que los términos que manejan cada una de las normas aplicables no sean equivalentes. Podemos constatar, por tanto, la existencia jurídica de dos géneros de paisaje, el natural y el cultural, que mantienen su autonomía, disponiéndose dos regímenes diferenciados de tutela para ambos patrimonios. Respecto del primero, el artículo 30 de la Ley 42/2007, relativo a las clases de espacios naturales protegidos, alude expresamente a la figura de los "paisajes protegidos" ${ }^{24}$ como "partes del territorio que las Administraciones competentes, a través del planeamiento aplicable, por sus valores naturales, estéticos y culturales, y de acuerdo con el Convenio del paisaje del Consejo de Europa, consideren merecedores de una protección especial” (art. 35). La gestión de estos debe llevarse a cabo con respeto a los fines de conservación de los valores singulares que caracterizan estos espacios y de preservación de la interacción armoniosa entre la naturaleza y la cultura en una zona determinada. Precisamente, en estos paisajes protegidos debe procurarse el mantenimiento de las prácticas de carácter tradicional en la medida que contribuyan a la preservación de sus valores y recursos naturales. En cuanto a la Ley 16/1985, ya hemos apuntado que no contiene definición alguna de paisaje.

Naturaleza y cultura constituyen aspectos integrantes del paisaje y la incidencia de cada uno de estos factores será mayor o menor en función de si ese espacio se localiza en un ámbito urbano o rural, pero igualmente se

\footnotetext{
${ }^{23} \mathrm{Se}$ ha afirmado al respecto que "todos los paisajes son culturales, pero no todos tienen interés patrimonial; e, incluso dentro de aquellos que sí lo tienen, se pueden encontrar distintos grados de interés: desde aquellos que expresan valores de representación a aquellos que manifiestan algún tipo de aspecto que los hace sobresalientes". FERNÁNDEZ SALINAS, V., "Los paisajes culturales: Aspectos generales y una mirada desde España", Álvarez Areces, M. Á., Paisajes Culturales. Patrimonio Industrial y Desarrollo Regional, INCUNA, Gijón, 2012, p. 47.

${ }^{24}$ En la misma línea de protección del medio natural, la biodiversidad y los ecosistemas, el Sistema de Áreas Protegidas elaborado por la International Union for Conservation of Nature (IUCN) incluye desde 1978 la categoría de "paisaje protegido", con la siguiente definición: "Área de terreno, que puede incluir costa y mar, donde la interacción de gente y naturaleza a lo largo del tiempo ha producido un espacio de carácter distintivo con unos valores estéticos, ecológicos y/o culturales específicos, y a menudo con una rica diversidad biológica".
} 
sobreponen a la propia idea del paisaje. Y es que el paisaje refleja una realidad compleja habida cuenta de que yuxtapone componentes de variada naturaleza no solo naturales y culturales, sino también materiales e inmateriales. Así, puede decirse que: a) la mayor parte de las veces el paisaje urbano se ve condicionado por su entorno natural, que es parte integrante de este; y b) aunque estemos en presencia de un paisaje compuesto por recursos naturales, también concurren en él unos valores culturales asociados que lo hacen singular. En este sentido, se ha afirmado que, a pesar de su recíproca autonomía, entre patrimonio cultural y patrimonio natural subsiste una relación de complementariedad mutua ${ }^{25}$.

La filiación de la noción legal de paisaje podría haberse mantenido irresoluta o en tablas de no ser por la evolución conceptual del patrimonio cultural, que ha experimentado una ampliación considerable, especialmente en la normativa autonómica. A raíz de los dictados internacionales ${ }^{26}$, la longa manus de la cultura como conjunto de valores de una sociedad dignos de ser conservados y transmitidos ha ido enriqueciendo progresivamente la noción de patrimonio cultural con la adición de nuevos intereses a proteger ${ }^{27}$. A mayor abundamiento, el patrimonio cultural también integra elementos del patrimonio natural, tal es el caso, por ejemplo, de los parques y jardines históricos y del paisaje $^{28}$. Bermejo Latre sostiene al respecto lo siguiente:

\footnotetext{
${ }^{25}$ ALVES CORREIA, F. y ALMEIDA AZEVEDO, B., "O regime jurídico de protecção e valorização do património cultural em Portugal", López Ramón, F. (coord.), El patrimonio cultural en Europa y Latinoamérica, INAP, Madrid, 2017, p. 87.

${ }^{26}$ La Recomendación sobre la Salvaguardia de la Cultura Tradicional y Popular de 1989 y, más tarde, la Convención para la Salvaguardia del Patrimonio Cultural Inmaterial de 2003 han ampliado la identificación del patrimonio cultural para aglutinar asimismo los bienes intangibles, superando la acepción recogida en la Convención sobre la Protección del Patrimonio Mundial Cultural y Natural de 1972, que se limitaba a objetos, construcciones o manifestaciones materiales del paisaje. Lo mismo puede decirse de la Recomendación sobre la Protección del Patrimonio Arquitectónico del siglo XX de 1991, el Convenio Europeo del Paisaje de 2000, la Convención sobre la Protección del Patrimonio Cultural Subacuático de 2001 y la Carta de Nizhny Tagil sobre el Patrimonio Industrial de 2003.

${ }^{27}$ Una muestra de ello es la noción global de paisaje que plantea el Convenio Europeo del Paisaje ("cualquier parte del territorio, tal y como es percibida por la población [...]"), que no se circunscribe en exclusiva al territorio como elemento físico y que se interrelaciona con la gente que lo habita. Esta línea evolutiva del concepto de paisaje se encuentra presente también en el Convenio Marco sobre el Valor del Patrimonio Cultural para la Sociedad, del Consejo de Europa (Faro, 2005).

${ }^{28}$ La STC 102/1995, de 26 de junio, describe el paisaje como "noción estética, cuyos ingredientes son naturales - la tierra, la campiña, el valle, la sierra, el mar-y culturales, históricos, con una referencia visual, el panorama o la vista, que a finales del siglo pasado
} 
Es fácil justificar las ampliaciones del ámbito del patrimonio cultural desde el concepto de la cultura que, en la definición del diccionario, equivale al "conjunto de conocimientos y modos de vida y costumbres que se dan en un pueblo o una época" [...]. Sin embargo, las funciones públicas no pueden organizarse exclusivamente desde la lógica de los conceptos, sobre todo habida cuenta de las posibles coincidencias en los correspondientes ámbitos de actuación de distintas funciones. [...] Conforme a cuanto estamos exponiendo, cabe constatar que la legislación autonómica ha mantenido e incrementado la indeterminación y la amplitud características del patrimonio cultural en el Derecho español. Así, en las enumeraciones más completas llegan a adicionarse a la lista estatal los intereses "antrópico", "mobiliario", "lingüístico", "social” e "industrial”, conceptos estos que no siempre admiten explicaciones plausibles sobre su alcance. Prácticamente todas las leyes autonómicas han añadido la referencia al interés "arquitectónico" o, en algunos casos, "urbanístico". En las más recientes regulaciones se advierte la tendencia a incluir la mención de los intereses "paisajístico" e incluso "natural" entrando así en eventual conflicto con la legislación relativa al patrimonio natural ${ }^{29}$.

En 1992, la Unesco se convierte en pionera al introducir en las normativas internacional y nacional de patrimonio la categoría de "paisajes culturales" (entendidos como el resultado de acoplar a la naturaleza la acción humana), puesto que hasta ese momento las categorías patrimoniales cultural y natural eran concebidas como realidades casi antagónicas ${ }^{30}$. En todo caso, cabe

obtiene la consideración de recurso, apreciado antes como tal por las aristocracias, generalizado hoy como bien colectivo, democratizado en suma y que, por ello, ha de incorporarse al concepto constitucional de medio ambiente".

${ }^{29}$ BERMEJO LATRE, J. L., "La indeterminación y amplitud del concepto de expolio del patrimonio cultural español”, López Ramón (coord.), El patrimonio cultural... cit., 2017, pp. 3536.

${ }^{30}$ Con su referencia a la protección de los "sitios", la Convención sobre la Protección del Patrimonio Mundial, Cultural y Natural de la Unesco (1972) puso la primera piedra para el reconocimiento del paisaje como bien patrimonial, aunque sin citarlo expresamente. En el año 1972, la Convención sobre la Protección del Patrimonio Mundial de la Unesco se convirtió en el primer instrumento jurídico internacional en reconocer y proteger los paisajes culturales. Así, la 16. ${ }^{a}$ sesión del Comité del Patrimonio Mundial en Santa Fe (1992) introdujo la categoría de 
resaltar que este organismo internacional exige que los paisajes culturales posean un valor universal excepcional, a diferencia de lo que dispondrá años después el Convenio Europeo del Paisaje ${ }^{31}$. Bajo la influencia de la Convención sobre la Protección del Patrimonio Mundial y de instrumentos internacionales posteriores —fundamentalmente, el Convenio Europeo del Paisaje-, el Estado y las comunidades autónomas han incorporado en su acervo jurídico una nueva "categoría" de bien del patrimonio cultural, el "paisaje cultural", como concepto integrador no solo de los aspectos naturales del espacio, sino también de sus valores culturales en sus diferentes manifestaciones fácticas posibles (paisajes naturales, rurales, periurbanos y urbanos), en las que concurren simultáneamente valores y atributos culturales y naturales. Entre los diversos instrumentos jurídicos que ponen el acento en el paisaje como bien cultural inmueble, destaca el Plan Nacional de Paisaje Cultural, aprobado por el Consejo del Patrimonio Histórico el 4 de octubre de 2012, que lo define como el "resultado de la interacción en el tiempo de las personas y el medio natural, cuya expresión es un territorio percibido y valorado por sus cualidades culturales, producto de un proceso y soporte de la identidad de una comunidad". También las comunidades autónomas han ido afianzando la noción de paisaje cultural, como, por ejemplo, la andaluza, que ha arbitrado mecanismos de protección y gestión en el marco de la Estrategia de Paisaje de Andalucía de $2012^{32}$.

\footnotetext{
"paisaje cultural" en el listado de bienes que conforman el patrimonio mundial (Operational Guidelines for the Implementation of the World Heritage Convention). Plan Nacional de Paisaje Cultural, pp. 3 y 46 . Accesible en:

$<$ http://ipce.mcu.es/conservacion/planesnacionales/paisajes.html> [última consulta: 8 de junio de 2017].

${ }^{31}$ Sobre las consecuencias para las áreas y sus habitantes derivadas de la delimitación de los paisajes culturales en el contexto de la Unesco y su carácter como factor de unidad o división del entorno, vid. BROCHOT, A., "The Paradoxes of Policy: Governance and Conflicts in Three Cultural World Heritage Landscapes", Luginbühl, Y., Howard, P. y Terrasson, D. (eds.), Landscape and Sustainable Development. The French Perspective, Ashgate, Dorchester, 2015, p. 216 y ss.

32 Acuerdo de 6 de marzo de 2012, del Consejo de Gobierno, por el que se aprueba la Estrategia de Paisaje de Andalucía. Documento accesible en:

<http://www.juntadeandalucia.es/medioambiente/portal_web/web/temas_ambientales/evaluacio n integracion_planificacion/planificacion_ambiental/estrategias/estrategia_paisaje/Estrategia_d e_Paisaje_de_Andalucia_2012.pdf> [última consulta: 12 de junio de 2017].
} 


\section{El marco jurídico regulador del paisaje en España. Contextualización} general

El análisis del marco jurídico regulador del paisaje en España debe partir, necesariamente, del Convenio Europeo del Paisaje de 2000, norma de referencia en esta materia y de aplicación en nuestro país al haber sido objeto de ratificación. Una vez examinado el Convenio, se señalan las principales normas aplicables en esta materia tanto a nivel estatal como autonómico, siendo precisamente este nivel el más interesante, toda vez que algunas comunidades autónomas se han dotado de normas cuyo objeto específico es la protección del paisaje. La perspectiva jurídica que la normativa del paisaje otorga a esta figura constituye la base sobre la que se construye el tratamiento legal urbanístico del paisaje, por lo que resulta de vital interés una aproximación a esta.

\section{El Convenio Europeo del Paisaje como norma clave de referencia}

El Convenio Europeo del Paisaje ${ }^{33}$, adoptado en Florencia el 20 de octubre de 2000 en el seno del Consejo de Europa, constituye un instrumento fundamental para la protección del paisaje y, hasta el momento, el paso más avanzado que en materia de protección paisajística se ha producido a nivel internacional ${ }^{34}$, sin perjuicio de que existan algunos precedentes de interés en esta materia ${ }^{35}$. Ratificado por España en noviembre de 2007 y en vigor desde el 1 de marzo de

\footnotetext{
${ }^{33}$ Sobre los orígenes y la gestación del Convenio Europeo del Paisaje, vid. DÉJEANT-PONS, M., "La Convención Europea del Paisaje", El paisaje y la gestión del territorio... cit., pp. 345346; y PRIORE, R., "Derecho al paisaje, derecho del paisaje", Paisaje y ordenación del territorio, Junta de Andalucía, Consejería de Obras Públicas y Transporte - Fundación Duques de Soria, Sevilla, 2002, pp. 95-99.

${ }^{34}$ FERNÁNDEZ RODRÍGUEZ, C., La protección del paisaje. Un estudio de Derecho español y comparado, Marcial Pons, Madrid, 2007, p. 82.

${ }_{35}$ Puede citarse la Carta del Paisaje del Mediterráneo, firmada por Andalucía, LanguedocRoussillon y Toscana en 1993, en el marco de la Conferencia del Consejo de Europa que reunió a autoridades locales y regionales y adoptó la Resolución 256/1994 (Tercera Conferencia de las Regiones Mediterráneas). En general, sobre los instrumentos internacionales de protección del paisaje y, en particular, sobre los precedentes del Convenio Europeo del Paisaje, vid. FERNÁNDEZ RODRÍGUEZ, La protección del paisaje... cit., p. 71 y ss.
} 
$2008^{36}$, el Convenio parte de una definición amplia del paisaje, considerando de tal condición "cualquier parte del territorio tal como la percibe la población, cuyo carácter sea el resultado de la acción y la interacción de factores naturales y/o humanos" [art. 1.a)]. De este modo, el paisaje no se circunscribe a los espacios protegidos desde una perspectiva exclusivamente ambiental, dado que, como se indica en el preámbulo del Convenio, el paisaje constituye un elemento importante de la calidad de vida de las poblaciones en cualquier parte, "en los medios urbanos y rurales, en las zonas degradadas y de gran calidad, en los espacios de reconocida belleza excepcional y en los más cotidianos"37. Esta interacción entre factores humanos y naturales es uno de los aspectos innovadores del Convenio y a él dedicaremos el siguiente apartado ${ }^{38}$.

En coherencia con esta concepción del paisaje, el ámbito de aplicación del Convenio se plantea en términos muy amplios, proyectándose sobre las zonas terrestre y marítima y las aguas interiores, así como sobre las áreas naturales, rurales, urbanas y periurbanas. Comprende asimismo tanto los paisajes que puedan considerarse excepcionales como los paisajes cotidianos o degradados. Todo ello, con el fin de constituir un nuevo instrumento consagrado exclusivamente a la protección, gestión y ordenación de todos los paisajes de Europa ${ }^{39}$. Se abandona, así, la visión exclusivamente elitista del paisaje, constituyendo esta regulación "una contribución esencial a las políticas de ordenación del territorio" ${ }^{40}$. De esta forma, el paisaje se reconoce de manera independiente de su valor excepcional, en la medida en que todas las formas de paisaje condicionan la calidad de vida de los ciudadanos y merecen ser tenidas en cuenta en las políticas del paisaje ${ }^{41}$.

\footnotetext{
${ }^{36}$ Instrumento de Ratificación del Convenio Europeo del Paisaje de 6 de noviembre de 2007, publicado en el BOE núm. 31, de 5 de febrero de 2008.

${ }^{37}$ PRIEUR, M., "La Convención Europea del Paisaje", Administración de Andalucía. Revista Andaluza de Administración Pública, núm. 50, 2003, p. 20, pone de manifiesto que la Convención define el paisaje en todas sus dimensiones, si bien se abstiene de emitir juicios de valor, lo que conlleva dejar de considerar únicamente como paisajes dignos de interés los paisajes notables o extraordinarios.

${ }_{38}$ Vid. PIZZIOLO, G., "Experiencia europea de valoración social del paisaje", Paisaje y ordenación... cit., p. 100.

${ }^{39}$ Vid. el preámbulo del Convenio Europeo del Paisaje.

${ }^{40}$ Según Prieur, el paisaje es un medio de vida y de calidad de la vida que conforma las culturas locales y constituye un factor de la identidad europea. "La Convención...", cit., p. 21.

${ }^{41}$ En este sentido, vid. DÉJEANT-PONS, “La Convención Europea...”, cit., p. 347.
} 
El objetivo fundamental del Convenio Europeo del Paisaje es promover la protección, gestión y ordenación de los paisajes, así como organizar la cooperación europea en este campo (art. 3). Pretende, en definitiva, partiendo del importante papel de interés general que el paisaje desempeña, contribuir a su protección, gestión y ordenación ${ }^{42}$ y responder a la aspiración general de disfrutar de paisajes de gran calidad y de participar activamente en su desarrollo, frenando su transformación. Para alcanzar estos objetivos, el Convenio incorpora una serie de medidas nacionales y de cooperación europea. Dentro de las medidas nacionales, que constituyen obligaciones para las partes firmantes, se incluyen medidas generales y medidas específicas. Con arreglo a las primeras, cada parte se compromete a lo siguiente (art. 5): a) "reconocer jurídicamente los paisajes como elemento fundamental del entorno humano, expresión de la diversidad de su patrimonio común cultural y natural y como fundamento de su identidad" ${ }^{\prime 3}$; b) definir y aplicar políticas destinadas a la protección, gestión y ordenación del paisaje mediante la adopción de medidas específicas ${ }^{44}$; c) establecer procedimientos para la participación pública $^{45}$, así como para la participación de las autoridades locales y regionales y otras partes interesadas en la formación y aplicación de las políticas en materia de paisaje; y d) integrar el paisaje en las políticas de ordenación

\footnotetext{
${ }^{42}$ La protección se orienta a conservar y mantener los aspectos significativos o característicos de un paisaje, que se justifican por su valor patrimonial derivado de su configuración natural y/o la acción del hombre [art. 1.d)]. La gestión del paisaje, por su parte, aglutina las acciones encaminadas a garantizar el mantenimiento regular de un paisaje con el fin de guiar y armonizar las transformaciones inducidas por los procesos sociales, económicos y medioambientales [art. 1.e)]. Finalmente, la ordenación urbanística comprende las acciones que presenten un carácter prospectivo particularmente acentuado con vistas a mejorar, restaurar o crear paisajes [art. 1.f)]. ${ }^{43}$ Fernández Rodríguez advierte de la indeterminación que planea sobre cómo debe producirse este reconocimiento jurídico, ya que, en los términos en que se expresa, bastaría con una mínima protección sectorial para un determinado tipo de paisaje, sin requerirse una protección general y global. La protección del paisaje... cit., p. 85.

${ }_{44}$ Resultan fundamentales, en este sentido, las diferentes técnicas nacionales de relación interadministrativa, de cooperación, participación y coordinación a través de las cuales se articula la protección del paisaje que no se integra específicamente ni desde el punto de vista material o funcional ni desde el territorial en un único título o centro competencial. Ibidem, $\mathrm{p}$. 85.

${ }^{45}$ Debe destacarse la relevancia de la participación pública en materia de paisaje. Como señala DÉJEANT-PONS, "La Convención Europea...", cit., p. 347, dada la amplitud del campo de aplicación del Convenio, el papel activo de los ciudadanos en relación con la percepción y la evaluación de los paisajes deviene un aspecto fundamental del Convenio. La sensibilización resulta asimismo esencial para facilitar que los ciudadanos participen en el proceso decisorio que afecta a la dimensión paisajística del territorio en el que viven.
} 
territorial y urbanística ${ }^{46}$, cultural, medioambiental, agrícola, social y económica, así como en cualesquiera otras políticas que puedan tener un impacto directo o indirecto sobre el paisaje. Además de definir y aplicar políticas específicas en materia de paisaje, es imprescindible integrar la protección del paisaje en las diferentes políticas o acciones sectoriales con incidencia sobre este. Este es, sin duda, uno de los retos más importantes del Convenio ${ }^{47,}{ }^{48}$. A estas medidas nacionales de contenido general se añaden otras específicas dirigidas a los Estados para que incorporen los planteamientos del Convenio en sus normativas internas ${ }^{49}$. Igualmente, se establecen un conjunto de medidas relativas a la cooperación europea en algunos ámbitos. Entre ellas, se prevé el compromiso de las partes de cooperar en el estudio de la dimensión paisajística de las políticas y programas internacionales y recomendar la inclusión de consideraciones relativas al paisaje. Asimismo, se establece el deber de asistencia mutua e intercambio de información y de favorecimiento de la cooperación transfronteriza a nivel local y regional y, en caso necesario, de

\footnotetext{
${ }^{46}$ Aquí se pone de manifiesto la estrecha interrelación entre paisaje, ordenación del territorio y urbanismo, en atención a "los especiales vínculos que se dan entre las citadas materias, ya que el paisaje es un elemento fundamental del urbanismo, en el sentido de determinar una integración armónica entre las diferentes construcciones y una utilización racional del suelo" (PÉREZ GONZÁLEZ, C., "Relaciones entre la ordenación urbanística y la protección del paisaje", Revista de Derecho Urbanístico y Medio Ambiente, núm. 243, 2008, p. 171). Sobre las sinergias entre paisaje, urbanismo y ordenación del territorio, vid. también, in totum, HERVÁS MAS, J., Ordenación del territorio, urbanismo y protección del paisaje, Dykinson, Madrid, 2009.

${ }^{47}$ Vid., al respecto, ZOIDO, "Principales retos de adaptación de la Convención Europea del Paisaje a las políticas de ordenación del territorio en Europa", El paisaje y la gestión del territorio... cit., pp. 359-374.

${ }^{48}$ Una de las obligaciones específicas de los Estados firmantes es la de identificar, analizar y caracterizar los paisajes propios. En cumplimiento de esta, se ha elaborado el Atlas de los Paisajes de España, accesible en:

$<$ http://www.mapama.gob.es/es/desarrollo-rural/temas/desarrollo-territorial/atlas-de-lospaisajes-de-espana.aspx> [última visita: 8 de junio de 2017].

${ }^{49}$ El Convenio también incluye cinco medidas específicas. En primer lugar, la sensibilización de la sociedad civil, las organizaciones privadas y las autoridades públicas respecto del valor de los paisajes, su papel y su transformación. En segundo lugar, la promoción de la formación y la educación. En tercer lugar, la identificación y calificación de los paisajes -a estos efectos, es imprescindible que las partes identifiquen sus propios paisajes en el territorio, analizando sus características y las fuerzas y presiones que los transforman, y califiquen los paisajes así definidos teniendo en cuenta los valores particulares que se les atribuyen-. En cuarto lugar, la definición de los objetivos de calidad paisajística para los paisajes identificados y calificados, previa consulta al público. Y, por último, la consecución de la aplicación de las políticas en materia de paisajes, para lo cual cada parte se compromete a establecer instrumentos de intervención destinados a la protección, gestión y/u ordenación del paisaje. Prieur señala que estos objetivos de calidad deben ser observados por el planeamiento urbanístico y respetados por las actividades individuales privadas o públicas como servidumbres de utilidad pública. Asimismo, considera que los planes deben reflejar las aspiraciones de las poblaciones y, por tanto, ser elaborados en estrecha colaboración con estas (PRIEUR, “La Convención...”, cit., p. 22).
} 
elaboración y realización de programas comunes en materia de paisajes (artículos 7-9) ${ }^{50}$.

A la vista de lo expuesto, no puede ocultarse la transcendencia del Convenio Europeo del Paisaje tanto por el posicionamiento que, en su momento, supuso en relación con el paisaje como por las medidas previstas para su protección, ordenación y gestión. Contiene, en definitiva, un verdadero decálogo del paisaje, alcanzándose un hito a nivel europeo ${ }^{51}$. Como atinadamente señala Prieur, el Convenio ha de servir de fuente de inspiración y de referencia a la política local y nacional, a las ONG medioambientales y las relacionadas con la conservación del patrimonio cultural y, en fin, a todos los actores económicos y sociales para erradicar los procesos de abandono de ciertos paisajes (por ejemplo, las entradas a las ciudades o los espacios agrícolas) y frenar la amenaza de banalización y de uniformidad de los asentamientos humanos que contradice la identidad cultural y la diversidad biológica de Europa ${ }^{52}$. La importancia del Convenio, como ha puesto de relieve Fernández Rodríguez, reside "en el influjo que la misma ha supuesto para la adopción de las legislaciones de carácter nacional y regional, asumiendo en muchos casos sus criterios de particular gestión, protección y ordenación del paisaje". En efecto, el Convenio ha sido y continúa siendo, una década después de su ratificación por España, un punto de referencia fundamental en la elaboración de legislaciones específicas sobre la materia.

\section{La inexistencia de normativa estatal específica sobre paisaje. La} protección del paisaje a través de múltiples normas sectoriales

A diferencia de lo que sucede a nivel autonómico, como se verá, en la actualidad no existe aún una legislación estatal específica reguladora del

\footnotetext{
${ }^{50}$ El Convenio no afecta a las disposiciones más estrictas en materia de protección, gestión y ordenación del paisaje contenidas en otros instrumentos nacionales o internacionales vinculantes vigentes o futuros (art. 12).

${ }^{51}$ Así lo pone de relieve PÉREZ GONZÁLEZ, "Relaciones entre la ordenación...", cit., p. 170.

${ }^{52}$ PRIEUR, “La Convención...”, cit., p. 25.
} 
paisaje $^{53}$. Ello no significa, sin embargo, la ausencia de normativa aplicable en esta materia. Efectivamente, por una parte, debe tenerse presente la aplicación del Convenio Europeo del Paisaje, en la medida en que ha sido ratificado por España, y, por otra, la protección del paisaje se contempla en abundante legislación sectorial (de costas, puertos, minas, espacios naturales protegidos, urbanismo, turismo, montes, etc.). Dentro de este conjunto normativo sectorial cobra especial relevancia para la protección del paisaje la normativa de protección de la naturaleza y la normativa urbanística -a esta última nos referiremos en el siguiente apartado-.

Las políticas medioambientales no han ignorado el valor del paisaje como elemento digno de protección, pero la atención a la singularidad de los paisajes, concebidos jurídicamente como espacios resultantes de la interacción de factores naturales y/o humanos, no se ha caracterizado por su precocidad. El legislador ambiental empieza su andadura proteccionista poniendo el acento en las áreas naturales vírgenes representativas de la diversidad de hábitats del planeta. Las primeras regulaciones ambientales, centradas en la preservación y protección del medio biofísico y de su diversidad, así lo atestiguan. Estas regulaciones se caracterizan por atender exclusivamente a finalidades de protección y conservación respecto de las zonas geográficas en las que concurren elementos de carácter extraordinario (singularidad, diversidad ecológica, endemicidad o fragilidad...), como sucede con la creación de los primeros parques nacionales ${ }^{54}$ a modo de reservas o museos naturales al aire

\footnotetext{
${ }^{53}$ En cambio, en Suiza, el interés por la protección del paisaje (aunque en un sentido conceptual más restrictivo que el contenido en el Convenio Europeo del Paisaje) se despertó muy tempranamente. La Confederación Suiza aprobó en julio de 1996 la Ley federal relativa a la protección de la naturaleza y el paisaje con el fin de proteger el patrimonio natural y el arquitectónico. En la Ley se determinan cuatro categorías de paisajes protegidos: Ios paisajes únicos en razón de su belleza, singularidad, importancia científica, ecológica, geográfica o cultural; los paisajes típicamente suizos; los amplios paisajes de relajación que invitan a los paseos y al descubrimiento de la naturaleza, que contribuyen al bienestar y la salud de la población y que participan en la formación de una identidad; y los monumentos naturales.

${ }^{54}$ Las políticas de protección de la naturaleza arrancan en la segunda mitad del siglo XIX en los Estados Unidos con la creación del Parque Nacional de Yellowstone (1871), al que seguirán los de Yosemite y Sequoia (1890). En España, la Ley de Parques Nacionales se aprueba en 1918, bajo cuya égida se crean los parques de los Picos de Europa y de Ordesa-Monte Perdido.
} 
libre ${ }^{55}$ y de otros espacios protegidos, como la designación autonómica de las ZEPA para asegurar la protección de todas las áreas que cumplen los criterios técnicos objetivos para ser clasificadas en esta categoría, de conformidad con la Directiva 79/409/CEE. Con el tiempo, sin embargo, las políticas ambientales amplían su radio de acción incorporando objetivos de desarrollo económico y humano sostenibles a tenor de los cuales el aprovechamiento de los recursos debe orientarse a una actividad productiva que permita el mantenimiento de las comunidades locales que habitan en los espacios naturales protegidos, sin menoscabo de estos. En efecto, los objetivos de protección frente al desarrollo urbanístico de los espacios naturales no hollados por la acción humana se ven superados por una visión más realista que asume que la incidencia de la actividad antrópica en la naturaleza es de tal intensidad que difícilmente existen parajes en el mundo que permanezcan vírgenes y no hayan sido modificados por la intervención del ser humano. Hoy en día, los espacios naturales protegidos responden a una finalidad plural que integra desde los tradicionales objetivos de protección, investigación científica y educación en valores hasta otros más novedosos centrados en el fomento socioeconómico (mantenimiento de comunidades humanas en las áreas geográficas protegidas, desarrollo de actividades económicas y recreativas...). Con ello no quiere decirse que esos objetivos socioeconómicos estuvieran totalmente ausentes de las políticas ambientales anteriores, pero es evidente que no eran prioritarios al considerarse en cierta manera incompatibles con los fines de protección ${ }^{56}$. Los ecosistemas terrestres y marítimos declarados reservas de la biósfera Programa MaB Hombre y Biosfera - son representativos de esta perspectiva, puesto que evidencian que la conservación no tiene por qué ser incompatible con el mantenimiento de actividades económicas, siempre que sean sostenibles y respetuosas con el medio.

\footnotetext{
${ }^{55}$ ALLI TURRILLAS, J. C., La protección de la biodiversidad. Estudio jurídico de los sistemas para la salvaguarda de las especies naturales y sus ecosistemas, Dykinson, Madrid, 2016, p. 114.

${ }^{56}$ Vid., por todos, el clásico estudio de LÓPEZ RAMÓN, F., La conservación de la naturaleza: los espacios naturales protegidos, Publicaciones del Real Colegio de España, Bolonia, 1980. Del mismo autor, "Régimen jurídico de los Parques Nacionales", Machado, A. (ed.), Los parques nacionales. Aspectos jurídicos y administrativos, MAPA, Madrid, 1988.
} 
Cabe destacar que tradicionalmente el paisaje aparece como principio inspirador de la normativa de espacios naturales protegidos. Así ocurre en la Ley 4/1989, de 27 de marzo, de Conservación de los Espacios Naturales y de la Flora y Fauna Silvestres (art. 2). También se incluyen referencias a la protección del paisaje en el artículo 10 de la Directiva 92/43/CEE del Consejo, de 21 de mayo de 1992, relativa a la conservación de los hábitats naturales y de la fauna y flora silvestres ${ }^{57}$. Y la Ley 42/2007, de 13 de diciembre, del Patrimonio Natural y de la Biodiversidad, tiene también, como hemos visto, especial incidencia en la protección del paisaje. En esta norma, el paisaje se define, a la manera del Convenio Europeo del Paisaje, como "cualquier parte del territorio cuyo carácter sea el resultado de la acción y la interacción de factores naturales y/o humanos, tal como la percibe la población" (art. 3.26). La protección del paisaje aparece además como uno de los principios de la Ley, que regula determinados aspectos de la política de paisaje ${ }^{58,59}$.

Como puede apreciarse, la protección del paisaje se contempla en la Ley 42/2007 íntimamente vinculada a la protección de espacios naturales protegidos $^{60}$. Se parte, para la articulación de esa protección jurídica, de la

\footnotetext{
57 "Cuando lo consideren necesario, los Estados miembros, en el marco de sus políticas nacionales de ordenación del territorio y de desarrollo y, especialmente, para mejorar la coherencia ecológica de la red Natura 2000, se esforzarán por fomentar la gestión de los elementos del paisaje que revistan primordial importancia para la fauna y la flora silvestres. Se trata de aquellos elementos que, por su estructura lineal y continua (como los ríos con sus correspondientes riberas o los sistemas tradicionales de deslinde de los campos), o por su papel de puntos de enlace (como los estanques o los sotos) resultan esenciales para la migración, la distribución geográfica y el intercambio genético de las especies silvestres".

${ }^{58}$ Así lo pone de manifiesto su exposición de motivos: "[...] la protección del paisaje se afirma como uno de los principios de la presente Ley y en ella se regulan aspectos puntuales de la política de paisaje, tales como la posibilidad de proteger algunos de ellos mediante figuras más generales o específicas de espacios naturales protegidos, la necesidad de que el análisis de los paisajes forme parte del contenido mínimo de los planes de ordenación de los recursos naturales, su utilización potencial como instrumento para dotar de coherencia y conectividad a la Red Natura 2000 y el fomento de las actividades que contribuyen a su protección como externalidad positiva cuando forme parte de un espacio protegido".

${ }^{59}$ Téngase también en cuenta la Ley 45/2007, de 13 de diciembre, para el desarrollo sostenible del medio rural, que incorpora la idea del paisaje como recurso para dinamizar estos espacios a la vez que dispone medidas encaminadas a su protección y conservación. Vid., además, el Programa Nacional de Desarrollo Rural 2014-2020, aprobado el 26 de mayo de 2015.

${ }^{60}$ Otros países han optado por separar el concepto de paisaje de los aspectos ambientales y de biodiversidad, priorizando la variable visual y estética e integrándolo en la misma normativa que rige el patrimonio arquitectónico. Así, el Código italiano de bienes culturales y del paisaje (Decreto Legislativo núm. 42/2004) y la Ley de Patrimonio holandesa de julio de 2016, que otorga al paisaje la categoría de monumento. STELLA RICHTER, P. y PARISIO, V., "Italie", p. 1, y HILLEGERS, S. y LAM, T., "National Report: the Netherlands", p. 1, XI International Urban
} 
declaración de una determinada zona como espacio natural protegido recordemos que la propia Ley incluye como categoría de espacio natural protegido los paisajes protegidos -61 . Con ello, se articulan elementos de protección del espacio declarado, aunque no se va más allá. Como ponen de relieve Lasagabaster Herrarte y Lazcano Brotons, "salvo supuestos puntuales, la única tutela que la normativa que analizamos dispensa es ad intra del espacio declarado. La protección ad extra vendrá determinada por la puesta en aplicación de otras normas e instrumentos: de ordenación territorial, urbanísticos, demaniales, etc. Esta apreciación resulta de particular interés si se ubican los elementos locales constitutivos del concepto de paisaje: el lugar de la percepción visual por los sujetos (a) y el del propio elemento percibido (b). La legislación de espacios naturales puede satisfacer más o menos adecuadamente la protección jurídica del paisaje cuando el elemento (b) se incardina dentro del área declarada como espacio a proteger, con independencia del lugar en el que se ubique el elemento (a), pero no cuando los términos de esta relación se alteran. Por ello son de particular interés aquellas previsiones legales que establecen la obligación jurídica de proteger el paisaje en el ejercicio de otras políticas sectoriales, al margen de que la zona afectada en cuestión haya sido o vaya a ser declarada como espacio protegido" 62 .

3. El diseño de estrategias de paisaje en la legislación autonómica; en especial, el marco jurídico de protección, gestión y ordenación del paisaje en Cataluña

\footnotetext{
Law Congress, Architectural Heritage, Sites and Landscapes Seized by Urban Law, Barcelona, septiembre de 2017, p. 1.

61 Vid. los artículos 29 y 34 de la Ley 42/2007. Los paisajes protegidos son las partes del territorio que las administraciones competentes, a través del planeamiento aplicable, consideren merecedoras de una protección especial por sus valores naturales, estéticos y culturales. Los objetivos principales de la gestión de estos espacios son los siguientes: la conservación de los valores singulares que los caracterizan y la preservación de la interacción armoniosa entre la naturaleza y la cultura en una zona determinada. En estas zonas se procurará el mantenimiento de las prácticas de carácter tradicional que contribuyan a la preservación de sus valores y recursos naturales.

62 LASAGABASTER HERRARTE, I. y LAZCANO BROTONS, Í., "EI régimen jurídico de la protección del paisaje", Lasagabaster Herrarte, I. (dir.), Derecho Ambiental. Parte Especial I. Espacios Naturales, Flora y Fauna, Montes, Paisaje, LETE, Pamplona-Bilbao, 2007, pp. 597598.
} 


\section{a) Estado de la cuestión}

En desarrollo de sus competencias ${ }^{63}$, algunas comunidades autónomas se han dotado de una regulación específica en materia de paisaje que contempla instrumentos de intervención para la protección, gestión y ordenación de este, en la línea de lo establecido por el Convenio Europeo del Paisaje. Dicha legislación aspira a proporcionar una protección jurídica adecuada a los paisajes atendiendo a su carácter de patrimonio ambiental, cultural, social e histórico y a su influencia en la calidad de vida de los ciudadanos. Pionera en este sentido ha sido la Comunidad Valenciana mediante la derogada Ley 4/2004, de 30 de junio, de Ordenación del Territorio y Protección del Paisaje, desarrollada a través del Decreto 120/2006, de 11 de agosto, por el que se aprueba el Reglamento del Paisaje (aunque, en la actualidad, resulta de aplicación la Ley 5/2014, de 25 de julio, de la Generalitat, de Ordenación del Territorio, Urbanismo y Paisaje, de la Comunitat Valenciana $)^{64}$. A ella le ha seguido Cataluña, que también ha aprobado un conjunto normativo muy innovador: la Ley $8 / 2005$, de 8 de junio, de protección, gestión y ordenación del paisaje, y el Decreto 343/2006, de 19 de septiembre, que la desarrolla. Posteriormente se han unido a este grupo Galicia, mediante la aprobación de la Ley $7 / 2008$, de 7 de julio, de Protección del Paisaje; Cantabria, con la Ley 4/2014, de 22 de diciembre, del Paisaje; y el País Vasco, con el Decreto 90/2014, de 3 de junio, sobre protección, gestión y ordenación del paisaje. En la lógica de aunar en una misma normativa la ordenación territorial y el paisaje se ha situado recientemente la Comunidad Foral de Navarra. Aunque dispone de normativa en materia de patrimonio cultural (Ley Foral 14/2005) y de espacios naturales (Ley Foral

\footnotetext{
${ }^{63}$ Andalucía, Galicia, Cataluña, Islas Baleares, La Rioja y Comunidad Valenciana tienen reconocidas estatutariamente competencias en paisaje. En el resto de casos, la competencia en la materia se anuda a otros títulos competenciales. Así, por ejemplo, el Estatuto de Autonomía de Aragón reconoce competencia exclusiva a esta comunidad sobre espacios naturales protegidos, lo que incluye la regulación y declaración de las figuras de protección, así como la delimitación, planificación y gestión de estos y de los hábitats protegidos. Asimismo, Aragón es competente para dictar normas adicionales a la legislación básica sobre protección del medio ambiente y del paisaje (art. 71.21 y .22 de la Ley Orgánica 5/2007, de 20 de abril).

${ }^{64}$ Sobre la legislación valenciana en materia de paisaje, vid. FERNÁNDEZ RODRÍGUEZ, C., "El estreno de nuestro Derecho en la ordenación paisajística: a propósito de la ordenación y protección del paisaje en la legislación valenciana", Revista de Administración Pública, núm. 172, 2007, pp. 363-401.
} 
9/1996) que da cuenta del paisaje en sus respectivas perspectivas, el Decreto Foral Legislativo 1/2017, de 26 de julio, por el que se aprueba el Texto Refundido de la Ley Foral de Ordenación del Territorio y Urbanismo, contempla una serie de medidas encaminadas específicamente a regular el paisaje como parte integrante de la sostenibilidad que ya fueron incluidas en la Ley Foral $5 / 2015$, de 5 de marzo, de medidas para favorecer el urbanismo sostenible, la renovación urbana y la actividad urbanística en Navarra ${ }^{65}$. Otras comunidades, como Castilla-La Mancha, ultiman sus anteproyectos de ley.

\section{El resto de comunidades autónomas se rigen por su legislación específica en} materia de patrimonio cultural o de espacios naturales, con citación expresa o no de la figura del paisaje (o paisaje cultural) ${ }^{66}$. Sí lo hacen, bien definiéndolo

\footnotetext{
${ }^{65}$ Lógicamente, debido a la naturaleza de la citada norma, se repiten los requerimientos vinculados a la atención al paisaje previstos en la normativa derogada: adaptación al ambiente y prohibición de limitar el campo visual y de quebrar la armonía del paisaje (art. 86), evitar su degradación (artículo 51, sobre criterios para el desarrollo del Plan General Municipal), favorecer la preservación del paisaje mediante el establecimiento de criterios que garanticen una protección extensiva y no reduccionista de este (artículo 52, sobre determinaciones sobre desarrollo sostenible) y fijación de estrategias, directrices y medidas para la protección y recuperación del paisaje a través de la Estrategia Territorial de Navarra como instrumento de planificación estratégica del territorio (arts. 31 y 32). Destaca la demanda expresa - por recomendación del Consejo Social de Política Territorial- de incorporar una política del paisaje en los usos del suelo mediante la necesaria adopción por los instrumentos de ordenación territorial y urbanística de la variable paisajística. Para ello, le corresponde al Gobierno de Navarra elaborar una "Estrategia Navarra del Paisaje" conforme a los requerimientos del Convenio Europeo del Paisaje (disposición adicional undécima). La Comisión de Paisaje del Consejo Social de Política Territorial ha llevado a cabo en los últimos años una labor de delimitación de áreas y unidades paisajísticas de conformidad con la clasificación del Atlas de los Paisajes de España con el objeto de proceder a la posterior catalogación de los espacios.

${ }^{66}$ En materia de patrimonio cultural podemos citar las siguientes normas: Ley 9/1993, de 30 de septiembre 1993, del Patrimonio Cultural Catalán; Ley 4/1998, de 11 de junio 1998, del Patrimonio Cultural Valenciano; Ley 11/1998, de 13 de octubre, de Patrimonio Cultural de Cantabria; Ley 3/1999, de 10 de marzo, del Patrimonio Cultural Aragonés; Ley del Principado de Asturias 1/2001, de 6 de marzo, de Patrimonio Cultural; Ley 12/2002, de 11 de julio, de Patrimonio Cultural de Castilla y León; Ley $7 / 2004$, de 18 de octubre, de Patrimonio Cultural, Histórico y Artístico de La Rioja; Ley Foral 14/2005, de 22 de noviembre, del Patrimonio Cultural de Navarra; Ley 14/2007, de 26 de noviembre, del Patrimonio Histórico de Andalucía; Ley 4/2007, de 16 de marzo, de Patrimonio Cultural de la Comunidad Autónoma de la Región de Murcia; Ley 3/2013, de 18 de junio, de Patrimonio Histórico de la Comunidad de Madrid; etc. A este cuadro normativo se le añade la legislación sobre espacios naturales protegidos -por contener elementos y sistemas naturales de especial interés 0 valores naturales sobresalientes-, entre los cuales se regula la figura de los denominados "paisajes protegidos", previstos en la Ley estatal 42/2007. A título ejemplificativo, podemos citar el Decreto Legislativo 1/2000, de 8 de mayo, por el que se aprueba el Texto Refundido de las Leyes de Ordenación del Territorio de Canarias y de Espacios Naturales de Canarias. Esta norma regula los planes de espacios naturales protegidos — planes de ordenación integral con capacidad para clasificar, calificar y categorizar pormenorizadamente la totalidad del suelo-, dentro de cuya tipología se sitúan los planes especiales de los paisajes protegidos (art. 14.2). Por su parte, el Decreto Legislativo 1/2015, de 29 de julio, por el que se aprueba el texto refundido de la Ley de Espacios Protegidos de Aragón, establece que los paisajes protegidos se ordenan mediante planes
} 
directamente o bien en el marco de la protección de otros bienes, autonomías como la Comunidad Foral de Navarra, Murcia, Cataluña, la Comunidad Valenciana, Cantabria, La Rioja y Asturias. En paralelo a la actividad legislativa, pueden destacarse iniciativas de otra índole, como la formulación de instrumentos vinculados a la ordenación territorial, de distinto alcance y contenido, denominadas directrices, estrategias, atlas, catálogos, cartas y mapas del paisaje (Andalucía, Canarias, Aragón, La Rioja, etc.). Algunas comunidades han creado organismos específicos como entidades de apoyo, asesoramiento y colaboración en todas las cuestiones relacionadas con la elaboración, aplicación y gestión de las políticas de paisaje, como el Observatorio Gallego del Paisaje.

La extensión de este trabajo impide realizar una aproximación a las distintas regulaciones autonómicas en materia de paisaje, pero ello no es óbice para que no nos detengamos, ni que sea someramente, en el estudio de una de ellas para dar cuenta de los avances producidos en este campo. En este caso se ha optado por abordar la legislación de paisaje catalana, puesto que constituye la más desarrollada hasta el momento en esta materia ${ }^{67}$. Dicha normativa

rectores de uso y gestión que fijan las normas para su uso y conservación y las directrices de actuación de la Administración y de los particulares (arts. 13 y 32 y ss.). También podemos mencionar la Ley 5/1991, de 5 de abril, de protección de los Espacios Naturales del Principado de Asturias, y el Decreto 38/1994, de 19 de mayo, que desarrolla el Plan de Ordenación de los Recursos Naturales de Asturias como documento marco para la protección de los recursos naturales en esta comunidad. Este plan prevé la creación de la Red Regional de Espacios Naturales Protegidos, estructurada en distintos tipos y niveles de protección, entre los cuales se hallan los paisajes protegidos, para cada uno de los cuales debe elaborarse un plan protector con directrices de actuación que garanticen que las actividades a desarrollar no alterarán los valores que se protegen en la zona. Los paisajes protegidos se regulan asimismo en la Ley 4/2006, de 19 de mayo, de Conservación de la Naturaleza de Cantabria.

La casuística jurisprudencial sobre paisajes protegidos es abundante -especialmente en relación con la Comunidad Autónoma canaria y, en menor medida, valenciana-. Pueden consultarse, entre otras, las SSTS de 10 de diciembre de 2003, 14 de diciembre de 2005, 15 de noviembre de 2006, 15 de febrero y 10 de julio de 2007, 10 de junio y 21 de julio de 2008, 10 de diciembre de 2009, 5 de mayo y 26 de noviembre de 2010, 11 de febrero y 11 de abril de 2011, 19 de enero y 17 de mayo de 2012, 9 de julio y 13 de diciembre de 2013, 18 de mayo y 23 de abril de 2015, 4 de julio de 2016 y 17 de marzo de 2017. A nivel autonómico podemos destacar las SSTSJ de Canarias de 10 de mayo, 6 de junio y 27 de julio de 2012, 27 de septiembre de 2013, 1 de septiembre de 2014, 9 de junio de 2015 y 28 de enero, 15 de marzo y 2 de noviembre de 2016; y las SSTSJ de la Comunidad Valenciana de 29 de abril de 2008, 18 de diciembre de 2009, 12 de julio de 2010 y 4 de diciembre de 2012.

Según la doctrina, los paisajes protegidos son la categoría protectora de ámbito estatal menos aplicada, a excepción de las áreas marinas protegidas, y las Comunidades Autónomas que la han empleado, lo han hecho conforme a criterios muy heterogéneos. Alfonso Mulero Mendigorri, "Significado y tratamiento del paisaje en las políticas de protección de espacios naturales de España", en Boletín de la Asociación de Geógrafos Españoles, núm. 62, p. 143.

${ }^{67}$ LASAGABASTER HERRARTE y LAZCANO BROTONS, "El régimen jurídico de la protección...", cit., p. 568. 
constituye "un ejemplo más de la transversalidad de la función pública de protección del medio ambiente que se subraya si consideramos que esta es una Ley que tiene su origen en el Departamento de Política Territorial y Obras Públicas y no en el Departamento de Medio Ambiente y Vivienda"68. No obstante, y a salvo de mayor concreción, los instrumentos de protección, gestión, ordenación, sensibilización, concertación y financiación de las políticas del paisaje que se contienen en la normativa autonómica son harto similares en cumplimiento de las obligaciones del Convenio Europeo del Paisaje. Así, en el País Vasco, las previsiones relativas a la catalogación de zonas visuales merecedoras de tratamiento paisajístico especial y la exigencia de estudio paisajístico respecto de las obras y actuaciones que quiebren el modelado del paisaje, previstas en las Directrices de Ordenación Territorial del País Vasco (Decreto 28/1997, de 11 de febrero), se desarrollan en el ámbito de la ordenación del territorio y el urbanismo mediante el Decreto 90/2014. Esta norma recoge los siguientes instrumentos jurídicos: los catálogos del paisaje (documentos descriptivos y prospectivos de referencia que delimitan las áreas geográficas establecidas, fijan las unidades del paisaje y las áreas de especial interés paisajístico y definen los objetivos de calidad paisajística); las determinaciones del paisaje (criterios extraídos de los catálogos del paisaje que desarrollan para cada unidad de paisaje los objetivos de calidad paisajística e identifican las medidas para su consecución); los planes de acción del paisaje (herramientas de gestión que, sobre la base de los instrumentos anteriores, concretan las acciones que deben llevarse a cabo, especialmente en áreas de especial interés paisajístico); y los estudios de integración paisajística (documentos técnicos que determinan las consecuencias de la ejecución de proyectos de obras y actividades en el paisaje y las medidas para garantizar su integración) ${ }^{69}$. Mientras que los catálogos y las determinaciones del paisaje se localizan en sede de planeamiento territorial, los planes de acción del paisaje y los estudios de integración paisajística lo hacen,

\footnotetext{
${ }^{68}$ VADRÍ I FORTUNY, M. T., "Política ambiental de Cataluña", López Ramón, F. (coord.), Observatorio de Politicas Ambientales 1978-2006, Thomson-Aranzadi, Cizur Menor, 2006, p. 601.

69 Vid. DEPARTAMENTO DE MEDIO AMBIENTE, PLANIFICACIÓN TERRITORIAL Y VIVIENDA, Guía para la elaboración de estudios de integración paisajistica en la Comunidad Autónoma del País Vasco, Tecnalia, Vitoria-Gasteiz, 2016.
} 
respectivamente, en fase de planeamiento urbanístico y de intervención administrativa. La Ley $7 / 2008$, de 7 de julio, de protección del paisaje de Galicia, se nutre de los mismos instrumentos, con sensibles variaciones de detalle en su denominación y contenido (catálogos del paisaje de Galicia, directrices del paisaje, estudios de impacto e integración paisajística y planes de acción del paisaje en áreas protegidas), mientras que la Ley valenciana 5/2014 asienta el reconocimiento jurídico del paisaje en los estudios de paisaje, los estudios de integración paisajística y los programas de paisaje ${ }^{70}$. La Ley cántabra 4/2014, de 22 de diciembre, del Paisaje, por su parte, se aparta un tanto de esta composición, ya que contempla, como instrumentos de ordenación, los planes especiales del paisaje, las directrices (con un contenido más estratégico, que deberán integrarse en la planificación territorial y urbanística) y los estudios del paisaje, y, como instrumentos de aplicación, los proyectos de actuación paisajística y los proyectos de restauración de paisajes degradados (ambos pensados para abordar la mejora y recuperación de paisajes de interés), así como los instrumentos de análisis de impacto e integración paisajística.

b) La Ley catalana en materia de paisaje: normativa vigente y perspectivas de futuro

i. La Ley $8 / 2005$, de 8 de junio, de protección, gestión y ordenación del paisaje

La Ley 8/2005 nace con la finalidad de regular los mecanismos necesarios para una protección jurídica adecuada del paisaje ${ }^{71}$. Sin embargo, como se

\footnotetext{
${ }^{70}$ De conformidad con el artículo 6.4 y los anexos I, II y III de la citada Ley, los estudios de paisaje analizan la ordenación urbana y territorial establecida por los planes sometidos a evaluación ambiental y territorial estratégica, fijando objetivos de calidad paisajística y medidas destinadas a su protección, ordenación y gestión. Los estudios de integración paisajística, por su parte, valoran los efectos sobre el paisaje de los planes que no se sujetan a tal evaluación, así como de los proyectos y actuaciones con incidencia en el paisaje, con establecimiento de medidas que eviten o mitiguen sus posibles efectos negativos. Finalmente, los programas de paisaje concretan las actuaciones necesarias para garantizar la preservación, mejora y puesta en valor de paisajes que requieren intervenciones específicas e integradas.

${ }^{71}$ Concretamente, tiene por objeto "el reconocimiento, protección, gestión y ordenación del paisaje, a fin de preservar sus valores naturales, patrimoniales, culturales, sociales y
} 
pone de manifiesto en su preámbulo, no pretende regular de modo omnicomprensivo todos los elementos que influyen en la producción y transformación del paisaje, sino servir de referencia a las legislaciones sectoriales que deben regular el impacto paisajístico de las actuaciones urbanísticas y de las infraestructuras productivas y extractivas, entre otras. A tal fin, impulsa la plena integración del paisaje en el planeamiento y en las políticas de ordenación territorial y urbanística, así como en las demás políticas sectoriales que inciden en este de forma directa o indirecta (art. 1). Parte, para ello, de una definición de paisaje prácticamente idéntica a la del Convenio Europeo del Paisaje y establece, en su artículo 2, una serie de principios que deben inspirar la actuación de los poderes públicos en este ámbito.

Sus disposiciones son aplicables al conjunto del territorio de Cataluña, tanto si el paisaje es el resultado de una acción humana intensa como si predominan los elementos naturales, sin perjuicio de lo que dispongan las normas, los planes y los programas en materia ambiental, agrícola, forestal y ganadera y el resto de la legislación sectorial que sea aplicable a determinados espacios o categorías de protección (art. 4). Como aspecto destacable, la Ley 8/2005 exige que los poderes públicos, en su ámbito competencial respectivo, integren, por medio de los diferentes planes y programas y de otras actuaciones, la consideración del paisaje en las políticas de ordenación territorial y urbanística, agrícola, forestal, ganadera, de infraestructuras, cultural, social, económica, industrial y comercial, y, en general, en cualquier otra política sectorial con incidencia directa o indirecta sobre el paisaje ${ }^{72}$.

Esta ley vela por la protección del paisaje y define los principales instrumentos de los que se dotan las administraciones públicas para reconocer jurídicamente sus valores y para promover actuaciones de conservación o mejora. Se trata, en definitiva, de hacer compatible el desarrollo económico y urbanístico con la

económicos en un marco de desarrollo sostenible" (art. 1). Con carácter previo a la aprobación de esta ley, el Parlamento de Cataluña, a través de la Resolución 364NI, de 14 de diciembre de 2000, acordó de forma unánime su adhesión al Convenio Europeo del Paisaje.

${ }^{72}$ Artículo 5 de la Ley catalana 8/2005, que se sitúa en la línea de lo establecido por el artículo 5 del Convenio Europeo del Paisaje. 
calidad del entorno, atendiendo a los valores patrimoniales, culturales y económicos.

Las actuaciones públicas que se ejecuten sobre el paisaje han de estar dirigidas a su protección, gestión y ordenación. En particular, estas actuaciones persiguen la preservación de los paisajes, especialmente cuando requieran intervenciones específicas e integradas para su mantenimiento; la mejora paisajística de las periferias y de las vías de acceso a las ciudades, así como la eliminación, la reducción y el traslado de los elementos, los usos y las actividades que los degradan; el mantenimiento, mejora y restauración de los paisajes agrícolas y rurales; la articulación armónica de los paisajes, con una atención particular hacia los espacios de contacto entre los ámbitos urbano y rural y entre los ámbitos terrestre y marino; la elaboración de proyectos de integración paisajística de áreas de actividades industriales y comerciales y de las infraestructuras; el fomento de las actuaciones de las administraciones locales y de las entidades privadas en la promoción y la protección del paisaje; la adquisición de suelo para incrementar el patrimonio público del suelo en las áreas que se consideren de interés para la gestión paisajística; y la atribución de valor al paisaje como recurso turístico ${ }^{73}$. En este marco general, la Ley prevé la cooperación en política de paisaje y también regula ampliamente los diferentes instrumentos de protección, gestión y ordenación del paisaje.

En efecto, la Ley 8/2005 crea diferentes instrumentos tendentes a materializar la consecución de estos fines. Algunos están destinados a integrarse en el planeamiento territorial (es el caso de los catálogos del paisaje y las directrices del paisaje) y otros, en cambio, se anudan a la fase de intervención administrativa (es el caso de las cartas del paisaje, cuya finalidad es promover la concertación entre los diferentes agentes territoriales para gestionar las transformaciones del paisaje $)^{74}$. Se incluye, asimismo, un

\footnotetext{
${ }^{73}$ Sobre las finalidades de las actuaciones sobre el paisaje, véase el artículo 8 de la Ley $8 / 2005$.

${ }^{74}$ Téngase en cuenta que el artículo 25 de la Ley 7/1985, de 2 de abril, Reguladora de las Bases del Régimen Local, reconoce las siguientes competencias en favor del municipio: a) "Urbanismo: planeamiento, gestión, ejecución y disciplina urbanística. Protección y gestión del patrimonio histórico. Promoción y gestión de la vivienda de protección pública con criterios de sostenibilidad financiera. Conservación y rehabilitación de la edificación; b) Medio ambiente
} 
instrumento económico, como es el Fondo para la Protección, Gestión y Ordenación del Paisaje, y se crea el Observatorio del Paisaje como ente de apoyo y colaboración de la Administración y de la sociedad en todas las cuestiones relacionadas con el paisaje. No se incluyen, sin embargo, instrumentos específicos de planificación paisajística, a diferencia de lo dispuesto en otras legislaciones autonómicas como la valenciana o la gallega $^{75}$. La Ley 8/2005 ha sido desarrollada mediante el Decreto 343/2006, de 19 de septiembre, cuyo objeto principal es desplegar los instrumentos que crea la Ley y, en particular, regular los procedimientos de aprobación de los catálogos del paisaje y de las directrices de paisaje, por medio de las cuales se integran en el planeamiento territorial y urbanístico las determinaciones necesarias para llevar a cabo las políticas que le afecten. También incluye la regulación de los estudios de impacto paisajístico establecidos en la legislación urbanística con el fin de garantizar el desarrollo armonizado de ambas normativas.

Los catálogos del paisaje son documentos que determinan la tipología de los paisajes de Cataluña y sus valores actuales y potenciales y proponen los objetivos de calidad ${ }^{76}$. Además de clasificar y relacionar los atributos y valores que presenta el paisaje, los catálogos del paisaje han de tener en cuenta las

urbano: en particular, parques y jardines públicos, gestión de los residuos sólidos urbanos y protección contra la contaminación acústica, lumínica y atmosférica en las zonas urbanas. [...]; d) Infraestructura viaria y otros equipamientos de su titularidad [...]; m) Promoción de la cultura y equipamientos culturales [...]". Sobre la participación de las entidades locales en la elaboración y aprobación de catálogos de paisaje y cartas de paisaje, vid. IGLESIAS LUCÍA, M., "Les competències locals en matèria de protecció, gestió i ordenació del paisatge", Casado Casado, L. y Fuentes Gasó, J. R. (dirs.), Dret ambiental local de Catalunya, Tirant lo Blanch, Valencia, 2017, pp. 738-742.

${ }^{75}$ Por ejemplo, la Ley gallega $7 / 2008$, de 7 de julio, incluye dentro de los instrumentos para la protección, gestión y ordenación del paisaje los planes de acción del paisaje en áreas protegidas. Vid. el artículo 8.4 en conexión con el artículo 12 de esta ley.

${ }^{76}$ Se trata de un instrumento vinculado al planeamiento territorial presente también, como se ha señalado, en otras normativas autonómicas. Así, por ejemplo, el artículo 4 del Decreto vasco 90/2014 regula los catálogos del paisaje como documentos de carácter descriptivo y prospectivo que abarcan la totalidad del paisaje de cada área funcional del territorio vasco con el objeto, entre otros objetivos, de delimitarlos, estableciendo las áreas de especial interés paisajístico e identificando las actividades y usos que incidan de forma más notoria en la configuración actual del paisaje. Asimismo, les corresponde la delimitación de las unidades de paisaje (ámbitos paisajísticamente coherentes susceptibles de sujetarse a un régimen específico de protección, gestión u ordenación del paisaje) y la definición de los objetivos de calidad paisajística, con propuesta de las medidas necesarias para alcanzar dichos objetivos. Estos catálogos constituyen el documento base para la redacción de las Determinaciones del Paisaje. 
relaciones e interacciones entre factores ambientales, culturales, sociales y económicos que explican su apariencia actual y la percepción que la ciudadanía tiene del paisaje. El alcance territorial de los catálogos del paisaje se corresponde con el de cada uno de los ámbitos de aplicación de los planes territoriales parciales (siete ámbitos funcionales territoriales). Dentro de cada ámbito, el catálogo ha de identificar, caracterizar y evaluar todo el territorio que integra el espacio del plan $^{77}$. En los espacios limítrofes entre dos planes territoriales parciales, debe velarse por la coherencia y continuidad de las unidades de paisaje ${ }^{78}$. La aprobación de los catálogos del paisaje corresponde al Departamento de Territorio y Sostenibilidad de la Generalitat, con unos trámites previos de información pública y de consulta a los entes locales y a las organizaciones económicas y sociales afectados. En cuanto a su naturaleza o valor jurídico, la Ley guarda silencio al respecto. Esto ha llevado a algún autor a señalar que se trata de meros documentos de trabajo de naturaleza interna de la propia Administración. Puesto que también se omite la naturaleza pública del catálogo o el acceso del público a este, "parece que se está incidiendo en la dirección de su patrimonialización como instrumento de trabajo interno cuyo contenido serviría para la elaboración de las directrices, aunque como mera propuesta, no con alcance preceptivo"79.

Mediante las directrices del paisaje se incorporan las propuestas de objetivos de calidad paisajística al planeamiento territorial. Se trata de determinaciones basadas en los catálogos del paisaje que precisan e incorporan normativamente las propuestas de objetivos de calidad paisajística en el planeamiento territorial (planes territoriales parciales, planes directores territoriales). Cabe destacar la utilización por la Ley 8/2005 del adverbio normativamente; de ello se deriva su valor normativo, si bien el alcance de ese

\footnotetext{
${ }^{77}$ A este efecto y de acuerdo con lo que establece el artículo 10 del Decreto 343/2006, el territorio que comprende el catálogo se divide en unidades de paisaje, entendidas como ámbitos estructural, funcional o visualmente coherentes sobre los que puede recaer, en parte o totalmente, un régimen específico de protección, gestión u ordenación en los términos que establece la Ley 8/2005. También se pueden delimitar áreas específicas. Vid. el artículo 3.2 del Decreto 343/2006. Sobre el concepto de "unidad de paisaje", vid. CORTINA, A., "La ley de protección, gestión y ordenación del paisaje de Cataluña", El paisaje y la gestión del territorio... cit., p. 412.

${ }^{78}$ En relación con las funciones de los catálogos del paisaje, vid. el artículo 4 del Decreto 343/2006.

${ }^{79}$ Fernández Rodríguez, La protección del paisaje..., op. cit., p. 152.
} 
valor va a ser determinado en cada caso por dichos planes territoriales, dado que les corresponde establecer los supuestos en los que las directrices del paisaje son de aplicación directa, los supuestos en que son de incorporación obligatoria cuando se produzca la modificación o la revisión del planeamiento urbanístico y los supuestos en que las actuaciones requieren un informe preceptivo ${ }^{80}$ del órgano competente en materia de paisaje (no concretado, sin embargo, por la Ley) ${ }^{81}$. Asimismo, los planes territoriales parciales y los planes directores territoriales también pueden determinar los casos en que las directrices del paisaje sean meras recomendaciones para el planeamiento urbanístico, para las cartas del paisaje y para otros planes o programas derivados de las políticas sectoriales que afecten al paisaje ${ }^{82}$. En este último supuesto, los planes o los programas que se aprueben deben ser congruentes con las recomendaciones de las directrices del paisaje ${ }^{83}$.

Junto a los catálogos y a las directrices del paisaje, la Ley 8/2005 también impulsa la creación y la utilización de nuevos instrumentos de concertación y sensibilización de estrategias sobre el paisaje entre los agentes públicos y los privados. Es aquí donde deben situarse las cartas del paisaje, cuyo contenido ha de tener en cuenta lo dispuesto por los catálogos del paisaje que inciden en su ámbito, así como por los catálogos del patrimonio cultural, artístico y natural de ámbito municipal en los casos en que estén aprobados. La Ley tampoco contiene ninguna previsión con relación al valor o naturaleza jurídica de las cartas del paisaje, al igual que sucede con los catálogos. En cualquier caso, como advierte Cortina, la carta del paisaje ha de ser un instrumento voluntario de concertación entre los agentes de un determinado territorio para promover la

\footnotetext{
${ }^{80}$ Nótese que, con arreglo a la Ley 8/2005, este informe es preceptivo, pero no vinculante.

${ }^{81}$ Como señalan LASAGABASTER HERRARTE y LAZCANO BROTONS, la Ley no establece cuál es ese órgano competente en materia de paisaje, por lo que habrá que entender que será el competente en materia de ordenación del territorio y medio ambiente. No obstante, como en algunos casos los órganos competentes en materia de ordenación del territorio y medio ambiente son diversos, sería interesante precisar a quién corresponde esta materia. "EI régimen jurídico de la protección...”, cit., p. 572.

82 El artículo 10.4 de la Ley $7 / 2008$, de 7 de julio, de protección del paisaje de Galicia, dispone, en cambio, que, una vez aprobadas, las normas recogidas en las directrices del paisaje tendrán carácter vinculante para los instrumentos de planificación sectorial y urbanística.

${ }^{83}$ Art. 12.2 de la Ley 8/2005. Aun cuando en este supuesto se trate de directricesrecomendaciones para el planeamiento urbanístico, las cartas del paisaje y otros planes 0 programas derivados de las políticas sectoriales que afecten al paisaje, los planes sectoriales no tienen preferencia respecto a las directrices.
} 
mejora de los paisajes y la calidad de vida de las comunidades; en ningún caso pretende ser una simple declaración testimonial de principios, sino un documento de carácter público y de compromiso a favor del paisaje entre las partes firmantes ${ }^{84}$.

ii. El Anteproyecto de Ley del Territorio de Cataluña: ¿el fin de la emancipación normativa del paisaje?

El Anteproyecto de Ley del Territorio de Cataluña ${ }^{85}$, actualmente en fase de información pública, contiene una serie de previsiones relativas al paisaje al tiempo que deroga la Ley 8/2005, que, como acabamos de ver, establece el marco regulatorio de esta materia. En su exposición de motivos pone de relieve que las legislaciones relativas al territorio (ordenación territorial, urbanismo, paisaje, entre otras) "configuran un cuerpo legislativo disperso en materias estrechamente relacionadas entre sí. Esta dispersión normativa, a la que hay que añadir el desfase temporal en su producción, ha sido un factor generador de diferencias reguladoras injustificadas que se armonizan a través del texto unitario de esta Ley" ${ }^{86}$. Por tal motivo, el legislador catalán renuncia a mantener una norma legal específica para regular el paisaje en beneficio de una mayor integración de las prescripciones paisajistas en el diseño de estrategias de ordenación territorial y urbana.

El paisaje ocupa en el Anteproyecto un lugar destacado que vamos a exponer seguidamente a grandes rasgos. Una novedad trascendental es el establecimiento de una nueva tipología de planes que aparta definitivamente a la Comunidad catalana del legado de la Ley de Suelo de 1956. Entre las nuevas figuras se regulan las denominadas "estrategias territoriales", que carecen de un ámbito espacial y material de aplicación predeterminado. Estas estrategias territoriales son de obligada aprobación a fin de que todo el territorio

\footnotetext{
${ }^{84}$ CORTINA, “La ley de protección, gestión y ordenación...”, cit., p. 418.

${ }^{85}$ Versión de abril de 2017.

${ }^{86}$ Es en este sentido que Cortina y Queralt afirman lo siguiente: "La fragmentación y sectorialización de la regulación del paisaje trae como consecuencia su insuficiente protección". CORTINA, A. y QUERALT, A., "La regulación específica del paisaje en la legislación autonómica", Ministerio de Medio Ambiente, Convenio Europeo del Paisaje. Textos y comentarios, Gobierno de España, Madrid, 2007, p. 61.
} 
mantenga una base de planificación territorial que establezca los criterios generales de desarrollo de los asentamientos urbanos, de preservación de los espacios abiertos y de implantación de las infraestructuras relativas a los sistemas urbanísticos. La obligación se amplía a las estrategias territoriales para delimitar las unidades de paisaje y para establecer las normas de aplicación a los espacios abiertos teniendo en cuenta las características homogéneas de cada unidad de paisaje (art. 92).

El Anteproyecto asume la regulación de las cartas del paisaje como instrumentos específicos de concertación que definen los objetivos de calidad paisajística de un territorio y programan las actuaciones para lograr su consecución (art. 28) y de las directrices generales para la planificación en materia de paisaje (art. 30) ${ }^{87}$. Se incorporan las directrices para la planificación de los espacios abiertos —un trasunto del suelo no urbanizable-, entre las cuales destaca la preservación de los valores naturales, rurales y paisajísticos (art. 31), y las directrices para la planificación de los asentamientos urbanos, como el establecimiento de condiciones flexibles de edificación de las parcelas que permitan formular proyectos de edificación diferentes en armonía con el paisaje urbano (art. 32).

Otra novedad importante es la desaparición de la tríada clasificatoria tradicional (suelos urbano, urbanizable y no urbanizable). El territorio se divide en espacios abiertos y asentamientos urbanos (art. 35). En los asentamientos urbanos no sujetos a una actuación urbanística, los planes urbanísticos de actuación local pueden tener por objeto la protección del paisaje urbano (art. 102.3). En cuanto a la clasificación de los espacios abiertos, esta se dirigirá, entre otras finalidades, a garantizar la preservación y mejora de los espacios naturales, el paisaje y el patrimonio cultural rural como valor social y activo económico del territorio. La autorización de los usos y obras en los espacios abiertos se sujeta a la correcta integración ambiental y paisajística [art. 46.3.d)].

\footnotetext{
${ }^{87}$ Son directrices del paisaje: a) favorecer la evolución armónica del paisaje de acuerdo con los conceptos de utilización racional del territorio, de desarrollo urbanístico sostenible y de funcionalidad de los ecosistemas; b) preservar, con la adopción de medidas protectoras del paisaje, el derecho de la ciudadanía a vivir en un entorno culturalmente significativo; y c) considerar las consecuencias sobre el paisaje de cualquier actuación de ordenación y gestión del territorio y valorar los efectos de la edificación sobre el paisaje.
} 
Como deberes de los propietarios de terrenos situados en espacios abiertos se dispone la obligación de costear y, cuando corresponda, ejecutar las medidas correctoras necesarias para evitar la fragmentación de los espacios agrarios, para prevenir los riesgos naturales o tecnológicos, para preservar la calidad ambiental y paisajística —que puede requerir la reducción del volumen edificado en la finca afectada - o para otras finalidades justificadas (art. 47).

También el patrimonio público de suelo asume finalidades asociadas al paisaje, en concreto, la disposición de suelo de titularidad pública en espacios abiertos para protegerlos de los procesos indeseados de transformación urbanística o para mejorarlos paisajísticamente mediante actuaciones de demolición de edificaciones en situación de fuera de ordenación asimilada o de otro tipo [art. 205.d)].

\section{La dimensión urbanística del paisaje}

Junto a la normativa reguladora de los espacios naturales protegidos, también cobra relevancia a efectos de la protección del paisaje la normativa urbanística, que influye de forma decisiva en la conservación de los valores e identidad de este. En efecto, el derecho urbanístico atiende entre sus finalidades a la protección del patrimonio cultural mediante la conservación, la recuperación y la mejora de los inmuebles que lo integran, de los espacios urbanos relevantes, de los elementos y tipologías arquitectónicos singulares, de los paisajes de valor cultural e histórico y de las formas tradicionales de ocupación humana del suelo. Precisamente, de la confluencia entre el urbanismo y el paisajismo ha surgido en los Estados Unidos una nueva corriente o disciplina, el Landscape Urbanism, cuya raison d'être no es otra que la necesidad de reconciliar los asentamientos urbanos con su entorno proponiendo una serie de estrategias para conceptualizar y reestructurar los cambios medioambientales urbanos ${ }^{88}$. La explosión urbanística que se produce en España a finales de los años noventa del siglo $\mathrm{XX}$ y que nos ha conducido a un crecimiento urbano

${ }^{88}$ DEL POZO, C., "El paisaje como sistema dinámico: una inspiración para la ciudad contemporánea", Ciudad y Territorio, núm. 180, 2014, p. 249. 
desequilibrado es insostenible por las consecuencias que genera, entre ellas, la ineficiencia económica derivada del fuerte gasto energético, del mantenimiento de infraestructuras y de la prestación de servicios públicos, por no hablar del impacto ambiental negativo y de la segregación social por razón del nivel de renta. Este modelo de urbanización difusa y de baja densidad residencial característico del crecimiento urbanístico más reciente ha desoído las necesidades reales del territorio y ha afectado irreversiblemente a la fisonomía de nuestras ciudades y su entorno inmediato ${ }^{89}$, siendo las voces más críticas con estas prácticas urbanísticas las que han resonado en el seno de las instituciones comunitarias. El Parlamento Europeo llegó a aprobar al respecto un total de tres informes — no vinculantes_, el más demoledor de los cuales fue el Informe sobre el impacto de la urbanización extensiva en España en los derechos individuales de los ciudadanos europeos, el medio ambiente y la aplicación del derecho comunitario, que ha dado lugar a una serie de recomendaciones del Parlamento Europeo. Se trata de recomendaciones focalizadas en la revisión de la legislación que afecta al derecho de propiedad, en el control de los planes urbanísticos que inobservan los criterios de sostenibilidad ambiental y responsabilidad social, en la anulación de los desarrollos urbanísticos en curso que infringen el derecho comunitario — sobre todo en materia de adjudicación de contratos administrativos y cumplimiento de las disposiciones en materia de agua y de medio ambiente-, en la derogación de las figuras legales que favorecen la especulación (como el agente urbanizador), en el incremento de la operatividad de los mecanismos administrativos y judiciales y en el fomento de la participación ciudadana en los procesos urbanísticos ${ }^{90}$. En este marco de realidad, el paisaje se ha visto

\footnotetext{
${ }^{89}$ Vid. el Libro Blanco de la Sostenibilidad en el Planeamiento Urbanístico Español (Ministerio de la Vivienda, 2010), que contiene un decálogo para guiar la formulación, bajo criterios de sostenibilidad, del planeamiento urbanístico, con el objetivo primordial de frenar la ocupación extensiva del suelo y de primar la reutilización y rehabilitación del patrimonio construido y del entorno urbano y periurbano degradado.

90 Vid. la Resolución del Parlamento, de 13 de diciembre de 2005, sobre los presuntos abusos de la Ley reguladora de la actividad urbanística y sus repercusiones para los ciudadanos europeos (DON C 286 E de 23 de noviembre de 2006); la Resolución del Parlamento, de 21 de junio de 2007, sobre los resultados de la misión de investigación en las Comunidades Autónomas de Andalucía, Valencia y Madrid, en nombre de la Comisión de Peticiones (DON C 146 E de 12 de junio de 2008); y la Resolución del Parlamento, de 26 de marzo de 2009, sobre el impacto de la urbanización extensiva en España en los derechos individuales de los ciudadanos europeos, el medio ambiente y la aplicación del Derecho comunitario, con fundamento en determinadas peticiones recibidas (2008/2248 (INI).
} 
sometido a una tremenda presión (contaminación acústica, impacto visual, modificación de la identidad y el carácter del paisaje, etc.), acusando los efectos de los procesos masivos de artificialización del suelo y la implantación de infraestructuras de transporte ${ }^{91}$. Una de las consecuencias más notables ha sido la fragmentación de los paisajes, que constituye uno de los principales motivos del alarmante descenso de la fauna silvestre en Europa ${ }^{92}$. En equilibrada contraposición, el consenso social sobre las bondades de una utilización sostenible de los recursos ha comportado un incremento de la participación ciudadana en la formulación de las políticas urbanísticas ${ }^{93}$.

\section{La protección urbanística de los valores estéticos y culturales del paisaje en la primigenia normativa urbanística}

El valor del paisaje fue puesto de manifiesto en el ámbito urbanístico desde un buen principio, y por ello la primera ley urbanística estatal se comprometió con su protección mediante el establecimiento de un conjunto de medidas que, con las debidas adaptaciones, se mantienen vigentes en la actualidad. No en balde,

\footnotetext{
${ }^{91}$ En opinión de Fernando García Rubio: "Ese peligro de degradación viene de varios frentes: el desarrollo cada vez más agresivo de la agricultura, la gestión forestal, la actividad industrial y minera, la ordenación del territorio y el urbanismo (que, siendo instrumentos ambientalmente neutrales, pueden ser usados igualmente, deliberada o culposamente, para desproteger ambientalmente el entorno urbano), los transportes, infraestructuras, turismo y ocio, y, de forma más general, los cambios de la economía mundial. Lo que la adaptación al ambiente y otras técnicas de protección del paisaje urbano pretenden es que esos cambios en nuestra forma de vida no afecten negativamente al paisaje, procurando, en primer lugar, mantener el paisaje de una ciudad". GARCÍA RUBIO, F., "Régimen jurídico particular del paisaje urbano. Entre las determinaciones de adaptación al ambiente, las normas sectoriales y la regulación de la estética en el ámbito de la autonomía local", Gifreu Font, J., Bassols Coma, M. y Menéndez Rexach, Á. (dirs.), El derecho de la ciudad y el territorio. Estudios en homenaje a Manuel Ballbé Prunés, INAP, Madrid, 2016, p. 507.

${ }^{92}$ Sobre el fenómeno de la fragmentación de los paisajes a causa de la actividad urbanística, vid. AGENCIA EUROPEA DEL MEDIO AMBIENTE-OFMA, Fragmentación del paisaje en Europa, Gobierno de España, Madrid, 2013, p. 6 y ss.

${ }_{93}$ Como sostiene Cortina: "La dimensión ética de la nueva cultura del territorio y el conjunto de valores que adopta, implica que en la práctica se desarrollen propuestas y proyectos territoriales que surgen de los mismos agentes del territorio. La evolución de este fenómeno cultural y axiológico va más allá de la mera participación pública o del posicionamiento defensivo en un determinado conflicto territorial. Este proceso de empoderamiento cultural y ético del territorio y de los paisajes, en Cataluña, supone una implicación directa de los elementos más dinámicos de la sociedad civil organizada y de los ciudadanos más emprendedores". CORTINA, A., Nova cultura del territori i ètica del paisatge, Consell Assessor per al Desenvolupament Sostenible, Generalitat de Catalunya, Documents de recerca, 17, Barcelona, 2010, p. 139.
} 
la ordenación del territorio y el urbanismo son competencias autonómicas condicionadas en su ejercicio por la legislación básica estatal en materia de medio ambiente, que tiene una proyección territorial inherente (STC 149/1991), sin olvidar que ellas mismas persiguen la consecución de objetivos de protección ambiental. La Ley de Régimen del Suelo y Ordenación Urbana de 12 de mayo de 1956 articuló una serie de previsiones referidas expresamente a la protección y conservación del paisaje, tanto a nivel de planeamiento territorial como de planeamiento urbanístico. En relación con el primero, la Ley creó la figura de los planes provinciales, en cuyo contenido documental debían figurar unas normas urbanísticas para la defensa de las comunicaciones, de la naturaleza, del paisaje, del medio rural y del patrimonio artístico de las poblaciones, así como para la edificación sobre terrenos respecto de los cuales no hubiera planeamiento aprobado (art. 8.e). Sin perjuicio de su inclusión en los planes territoriales, el planeamiento urbanístico también podía ocuparse de la "ordenación de ciudades artísticas, protección del paisaje y de las vías de comunicación, conservación del medio rural en determinados lugares, saneamiento de poblaciones y a cualesquiera otras finalidades análogas" (art. 13). Esa protección tenía por objeto la conservación de determinados lugares o perspectivas del territorio nacional, a saber: "a) Bellezas naturales en su complejo panorámico o en perspectivas que convinieren al fomento del turismo; b) Predios rústicos de pintoresca situación, amenidad, singularidad topográfica o recuerdo histórico; c) Edificios aislados que se distinguen por su emplazamiento o belleza arquitectónica y parques y jardines destacados por la hermosura, disposición artística, trascendencia histórica o importancia de las especies botánicas que en ellos existan; d) Perímetros edificados que formen un conjunto de valores tradicionales o estéticos" (art. 15). Como colofón, la Ley de 1956 establecía que la protección, entendida como conservación y mejora, del paisaje, así como de otros elementos - como monumentos, jardines y parques naturales-, requería la inclusión de estos en catálogos aprobados por la Administración urbanística (art. 20). Finalmente, el artículo 60 introducía un criterio estético vinculado a la protección del paisaje en municipios sin plan de ordenación general: así, se establecía que las construcciones que se ejecutaran en suelo urbano o rústico debían adaptarse al ambiente estético de la localidad o sector para que no desentonaran del conjunto medio en que 
estuvieran situadas. Con esta finalidad, las construcciones en lugares inmediatos o que formaran parte de un grupo de edificios de carácter artístico, histórico, arqueológico, típico o tradicional habían de armonizar con este, de igual forma que, cuando sin existir conjunto de edificios, hubiera varios o alguno de gran importancia o calidad. Igualmente, en las carreteras y caminos de trayecto pintoresco, no se permitía que la situación, masa o altura de los edificios o de sus muros y cierres limitaran excesivamente el campo visual para contemplar las bellezas naturales o rompieran la armonía del paisaje.

\section{De la protección a la ordenación y gestión del paisaje}

Las previsiones de la Ley del Suelo de 1956 se han mantenido casi intactas en las modificaciones posteriores de la legislación estatal de suelo y en la normativa urbanística autonómica, con el importante aderezo de medidas más ambiciosas que buscan el desarrollo del paisaje como recurso mediante su ordenación y gestión sostenibles. En paralelo, también deben tenerse en cuenta los avances en la noción de paisaje contenidos en los instrumentos y estrategias procedentes de la escena supranacional, como la Carta Europea de Ordenación del Territorio (Torremolinos, 1983), entre cuyos objetivos particulares relativos a las áreas rurales próximas a las concentraciones urbanas destaca la demanda de mayores medidas para la conservación y ordenación del paisaje. La Estrategia Territorial Europea (Postdam, 1999), adoptada en el seno de la UE, además de promover el desarrollo de un sistema urbano equilibrado y policéntrico y de un sistema integrado de comunicaciones que facilite el acceso al territorio, apuesta por valorizar el patrimonio territorial (cultural y natural) en aras de la identidad regional y el mantenimiento de la diversidad mediante la conservación y el desarrollo creativo del paisaje cultural. Sus líneas básicas de actuación también contemplan acciones preventivas en el paisaje a consecuencia de la presión urbanística o del abandono del suelo, y la recuperación de los paisajes dañados por causas antrópicas. Un año después, en septiembre de 2000, la 12. ${ }^{a}$ Conferencia Europea de Ministros responsables de la ordenación del territorio (CEMAT) del Consejo de Europa aprobó en Hannover los "Principios directores para el desarrollo territorial sostenible del continente europeo", tomando como referencia la Estrategia de 
1999. Entre estos principios figuran los paisajes culturales como espacios sensibles de gran diversidad que se encuentran sujetos a importantes transformaciones y que, por ello, requieren una atención específica por parte de las políticas de ordenación del territorio estatales en conexión con las políticas sectoriales, en términos de protección, ordenación y gestión de esos paisajes. El Convenio Europeo del Paisaje de 2000 marca una nueva tendencia en diversos sentidos. En primer lugar, no orienta la regulación del paisaje al único fin de la protección. En segundo lugar, tampoco contempla exigencias valorativas para conformar esa categoría, habida cuenta de que este "existe como tal independientemente de sus méritos, sin necesidad de ser calificado como remarcable o especialmente bello, incorpora implícita aunque no explícitamente, la dimensión temporal o histórica — junto a la perceptiva - a través de las relaciones entre las fuerzas naturales y la acción humana que definen el carácter de cada paisaje, y destaca la idea de que se trata de una entidad completa, en la que los elementos naturales y culturales son considerados simultáneamente" ${ }^{94}$. También la Agenda Territorial de la UE (Leipzig, 2007) insiste en la conexión entre la política territorial y las sectoriales asociadas al territorio. Esta iniciativa intergubernamental de los Estados miembros de la UE no contiene menciones expresas al paisaje. Debe destacarse, igualmente, el Convenio Marco sobre el Valor del Patrimonio Cultural para la Sociedad del Consejo de Europa, firmado en Faro en 2005, focalizado en la conservación y el uso sostenible del patrimonio cultural europeo, en el que se incluye el paisaje, para garantizar la calidad de vida y el desarrollo humano, y que reconoce el disfrute del paisaje natural y urbano como un derecho de los ciudadanos. Finalmente, puede traerse a colación la Estrategia Territorial de la UE 2020, aprobada en la reunión ministerial de los ministros responsables de ordenación del territorio y desarrollo territorial el 19 de mayo de 2011 en Gödöllő (Hungría). En esta se destaca que los cambios en los usos de las tierras, la urbanización y el turismo de masas constituyen una amenaza para los activos culturales y los paisajes y que el alto valor de los

\footnotetext{
${ }^{94}$ Ministerio de Educación, Cultura y Deporte, Plan Nacional de Paisaje Cultural de 2012, p. 5. Accesible en: <http://ipce.mcu.es/conservacion/planesnacionales/paisajes.html> [última consulta: 8 de junio de 2017].
} 
paisajes urbanos y rurales europeos debe protegerse y desarrollarse en términos cualitativos ${ }^{95}$.

\section{Instrumentos urbanísticos para la protección y ordenación del paisaje}

a) Breve mención al planeamiento territorial

Aunque no es objeto de este trabajo, es evidente que el planeamiento territorial tiene una función esencial en la ordenación de los paisajes del territorio. Las políticas de ordenación territorial son competencia autonómica y sus contenidos y denominaciones pueden diferir sustancialmente. Pero, en términos generales, podemos afirmar que los planes territoriales desempeñan una función directiva al establecer las directrices y los objetivos básicos de la ordenación del territorio a nivel supramunicipal en relación con el emplazamiento de los centros residenciales y de producción, la protección de los espacios y del patrimonio urbanístico que vertebra el territorio, la preservación del paisaje, la cohesión social y el reforzamiento de la estructura nodal del territorio. Los planes urbanísticos, en cambio, más específicos y detallados, proyectan el desarrollo de las ciudades y sus inmediaciones, en coherencia y respetando siempre las determinaciones de los planes territoriales.

Los planes de ordenación territorial contienen criterios finalistas de desarrollo dirigidos a favorecer la diversidad del territorio; proteger los espacios naturales, agrarios y no urbanizables como componentes de la ordenación del territorio; preservar el paisaje como un valor social y un activo económico del

\footnotetext{
${ }^{95}$ La Estrategia Territorial de la Unión Europea 2020 dispone en su apartado $38 .^{\circ}$, p. 11, lo siguiente: "Las zonas ricas en paisajes naturales y culturales pueden necesitar una atención especial para sacar todo el partido a estos activos. La creación de empleos verdes y unas funciones recreativas reforzadas pueden complementar la conservación. La gestión local, regional y transregional del patrimonio cultural y natural es de la máxima importancia. Defendemos la protección, rehabilitación y utilización del patrimonio a través de un enfoque orientado a los territorios. También es importante mejorar la identidad regional y local reforzando la sensibilización y la responsabilidad de las comunidades locales y regionales hacia su entorno, paisaje, cultura y valores únicos".
} 
territorio; moderar el consumo de suelo; favorecer la cohesión social del territorio y evitar la segregación espacial de las áreas urbanas; facilitar una política de vivienda eficaz y urbanísticamente integrada; propiciar la convivencia de actividades y vivienda en las áreas urbanas y racionalizar la implantación de polígonos industriales o terciarios; aportar medidas de regulación y orientación espacial de la segunda residencia; y velar por el carácter compacto y continuo de los crecimientos. En el ámbito concreto del paisaje, le corresponde al planeamiento territorial fijar los objetivos y criterios orientativos para la ordenación e integración paisajística que deben ser tenidos en cuenta en la elaboración del planeamiento urbanístico, así como identificar aquellos espacios ubicados en suelo no urbanizable que deben ser objeto de protección en atención a sus especiales valores naturales, paisajísticos, histórico-culturales, patrimoniales, etc. Debe tenerse en cuenta, asimismo, la exigencia de evaluación ambiental de los planes con incidencia territorial, debiendo procederse a un análisis paisajístico que incluya medidas correctoras y compensatorias del impacto paisajístico ${ }^{96}$.

Algunas comunidades autónomas han establecido figuras propias para propiciar, ya sea a escala territorial o urbanística, un crecimiento urbano sostenible y respetuoso con los valores y patrones paisajísticos y morfológicos del territorio. Es el caso de la "infraestructura verde" prevista en la Ley valenciana 5/2014, de 25 de julio, de Ordenación del Territorio, Urbanismo y Paisaje (arts. 4-5), entendida como una red interconectada de los espacios de mayor valor ambiental, paisajístico y cultural que contribuye a vertebrar el territorio y dotarlo de continuidad. Forman explícitamente parte de esta: “i) Los

\footnotetext{
${ }^{96}$ Además de los planes de ordenación territorial, las comunidades autónomas pueden establecer instrumentos adicionales de fomento o apoyo en relación con las políticas concretas de paisaje. Tal es el caso, en Cataluña, del Fondo para la Protección, Gestión y Ordenación del Paisaje, como instrumento financiero de la Generalitat, con el fin de destinarlo a las actuaciones de mejoramiento paisajístico que se lleven a cabo, y el Observatorio del Paisaje, como órgano de apoyo y asesoramiento en materia paisajística. El Observatorio del Paisaje debe elaborar cada cuatro años un informe sobre el estado del paisaje en Cataluña que el Govern presentará al Parlamento. Y puede participar en las redes de los observatorios europeos del paisaje y en las iniciativas y los proyectos de investigación y difusión de conocimientos y metodologías que se adopten en el ámbito de la Unión Europea. Sin embargo, no tiene competencias sustantivas decisorias, centrándose su labor en tareas de asesoramiento y apoyo. Más allá de constituir un órgano de apoyo, "no se le otorga función específica alguna, ni siquiera informativa vinculante, ni objetivos concretos que haya de perseguir. Tampoco la Ley se refiere a herramientas 0 instrumentos determinados para la realización de sus tareas". FERNÁNDEZ RODRÍGUEZ, La protección del paisaje... cit., p. 154.
} 
espacios de interés paisajístico incluidos o declarados como tales en la Estrategia Territorial de la Comunitat Valenciana, en los instrumentos que la desarrollan, o los incorporados a la planificación a partir de los instrumentos propios de la ordenación y gestión paisajística" (art. 5.2.i).

b) Referencias al paisaje en la legislación de suelo estatal

El paisaje cuenta con reconocimiento jurídico en la normativa estatal de suelo. El Real Decreto Legislativo 7/2015, de 30 de octubre, por el que se aprueba el texto refundido de la Ley de Suelo y Rehabilitación Urbana, señala que, en virtud del principio de desarrollo territorial y urbano sostenible, las políticas públicas relativas a la regulación, ordenación, ocupación, transformación y uso del suelo deben propiciar el uso racional de los recursos naturales armonizando los requerimientos de la economía, el empleo, la cohesión social, la igualdad de trato y de oportunidades entre mujeres y hombres, la salud y la seguridad de las personas y la protección del medio ambiente, contribuyendo en particular a "la eficacia de las medidas de conservación y mejora de la naturaleza, la flora y la fauna y de la protección del patrimonio cultural y del paisaje" [art.3.2.a)].

La Ley del Suelo de 2007 reconoció, y la norma estatal de 2015 mantiene, un triple estatuto jurídico básico de los sujetos afectados por el urbanismo, que se encuadra gráficamente en tres centros concéntricos: el de la ciudadanía en general en su relación con el suelo y la vivienda, el de terceros privados que participan en la actividad urbanizadora en régimen de competencia y el clásico, esto es, el de los propietarios del suelo. En el primer nivel, el de la ciudadanía, se reconoce el derecho de todos a disfrutar de una vivienda digna, adecuada y accesible, libre de ruido y otras inmisiones contaminantes que superen los límites máximos admitidos por la legislación, y en un medio ambiente y un paisaje adecuados. En el reverso de la moneda, se impone el 
deber de respetar y contribuir a preservar el medio ambiente, el patrimonio histórico y el paisaje natural y urbano ${ }^{97}$.

c) Las determinaciones legales substantivas de aplicación directa y las directrices para el planeamiento urbanístico

Tanto si el municipio cuenta con una figura de planeamiento urbanístico como si no, la ordenación también puede venir impuesta directamente por la Ley a través de determinaciones urbanísticas de aplicación directa que establezcan restricciones sobre el uso del suelo o las construcciones. Además, la legislación urbanística posterior ha incorporado principios de actuación y directrices del planeamiento cuyos objetivos son la seguridad, el bienestar de la ciudadanía y el amparo de los valores dignos de protección.

Tradicionalmente, las determinaciones legales sustantivas de aplicación directa se han configurado como mandatos que regían en ausencia de planeamiento - o de determinaciones al respecto- para la preservación del medio ambiente y del patrimonio natural y cultural y para impedir la paralización de la actividad constructiva en el municipio, pero actualmente la jurisprudencia les reconoce una aplicabilidad de carácter directo, prevaleciendo sobre las determinaciones contenidas en el plan: "Es abrumadoramente reiterada la doctrina de este Tribunal —sentencia de 24 de octubre y 8 de noviembre de 1990, 16 de junio de 1993, 10 y 12 de abril de 1996 entre muchas otras-de que estos preceptos se aplican en todo caso, existan o no Planes de Ordenación y Normas Complementarias o Subsidiarias de Planeamiento y son de inexcusable cumplimiento" (STS de 21 de noviembre de 2000). Según la STSJ de Cataluña de 1 de abril de 2005, la aplicación de estas normas no requiere ningún desarrollo a través de otra disposición o acto administrativo, de forma que, si estos últimos (figura de planeamiento, instrumento de gestión, licencia, etcétera) contradicen alguna norma de aplicación directa, serán anulables a pesar de ajustarse al planeamiento vigente. ${ }^{97}$ Otros preceptos del Real Decreto Legislativo $7 / 2015$ relacionados con el paisaje son los
artículos $6,8,9$ (apartados $3 .^{\circ}, 4 .^{\circ}$ y $\left.6 .^{\circ}\right), 14,15,17,18,20,22,24,42$ y 43. 
En este marco, la autorización de obras y usos en suelo no urbanizable tiene que garantizar en todos los casos su preservación frente al proceso de desarrollo urbano, así como la máxima integración ambiental de las construcciones y las actividades autorizadas. Esta finalidad proteccionista de los valores estéticos del paisaje se localiza tanto en la normativa urbanística autonómica como en la de suelo estatal, estableciéndose que las instalaciones, construcciones y edificaciones se deben adaptar, en los aspectos básicos, al ambiente en que estén situadas. En consecuencia, en los lugares de paisaje abierto y natural, sea rural o marítimo, o en las perspectivas que ofrezcan los conjuntos urbanos de características histórico-artísticas, típicas y tradicionales, así como también en las inmediaciones de las carreteras y caminos de trayecto pintoresco, no se permite que la situación, volumen y altura de los edificios, muros y cierres o la instalación de otros elementos limiten el campo visual para contemplar las bellezas naturales, rompan la armonía del paisaje o desfiguren su perspectiva ${ }^{98}$. Las normas de aplicación directa de la Ley 2/2001, de 25 de junio, de Ordenación Territorial y Régimen Urbanístico del Suelo de Cantabria, (art. 34) mantienen esta tónica con un mandato claro de protección del paisaje. Así, en los espacios mencionados supra (lugares de paisaje abierto y natural, perspectivas que ofrezcan los conjuntos urbanos de características históricas, típicos o tradicionales e inmediaciones de las carreteras y caminos de trayecto pintoresco), se reitera la necesidad de adaptar las construcciones al entorno en el que se localicen, quedando particularmente prohibida la publicidad estática que por sus dimensiones, localización o colorido no cumpla las prescripciones exigidas por la norma, incluyéndose en el concepto de publicidad los carteles anunciadores de locales y establecimientos mercantiles. En los conjuntos urbanos, la tipología de las construcciones habrá de ser, asimismo, congruente con las características del entorno, y los materiales empleados para la rehabilitación de inmuebles y la renovación y acabado de fachadas, cubiertas y

\footnotetext{
${ }^{98}$ Puede traerse a colación la discusión sobre el impacto visual en el paisaje a consecuencia de la implantación de infraestructuras de energías renovables, como los parques eólicos. Sobre el alcance de la afectación visual de los proyectos de parques eólicos, vid. la STSJ de Castilla y León de 19 de octubre de 2011, que establece una distinción entre los conceptos de intervisibilidad, visibilidad y percepción visual y concluye, en este caso, que dicha instalación no produce un alto grado de distorsión del paisaje.
} 
cierres de parcelas deberán armonizar con el lugar en que vayan a emplazarse ${ }^{99}$.

A la vista de las disposiciones establecidas por las normas de aplicación directa, se evidencia una constante que no es otra cosa que el recurso a los conceptos jurídicos indeterminados vinculados a una noción estética del paisaje (limitación del campo visual, fractura de la armonía del paisaje, desfiguración de la perspectiva). Estos conceptos, que deben ser interpretados en el momento de su aplicación, tienen una innegable naturaleza reglada, aunque en su apreciación se introduzca una cierta subjetividad ${ }^{100}$. Es en este sentido que la STC 102/1995, de 26 de junio, aclara que el paisaje "no es solo una realidad objetiva sino un modo de mirar, distinto en cada época y cada cultura", y, en consecuencia, es palmariamente cambiante.

\section{d) Las determinaciones de los instrumentos de planeamiento urbanístico}

No puede ocultarse la importancia de la planificación urbanística para la protección y gestión del paisaje ${ }^{101}$ habida cuenta de que los planes urbanísticos, al establecer las diferentes tipologías de suelo y fijar limitaciones, criterios o condicionamientos sobre este, ya prefiguran o condicionan la

\footnotetext{
${ }^{99}$ Ténganse en cuenta, además, las disposiciones sobre paisaje contenidas en las normas urbanísticas regionales y los planes especiales para la protección del paisaje, así como en las áreas de interés paisajístico contenidas en el Plan de Ordenación del Litoral de Cantabria.

${ }^{100}$ A tenor de la STSJ de Cataluña de 2 de marzo de 2006, los conceptos jurídicos indeterminados solo admiten una respuesta a la cuestión de si la actuación urbanística es o no compatible con el entorno y con la minimización del impacto visual. El Tribunal considera que la aplicabilidad estricta del precepto exige una prueba clara y contundente de que se han producido los efectos graves que la norma trata de prevenir, por cuanto no toda la actividad humana de transformación del medio físico tiene que quedar entorpecida por aquel precepto. No obstante, Fernández Latorre cuestiona la excesiva discrecionalidad administrativa que existe en la valoración de los paisajes y destaca la necesidad de fijar criterios técnicos normativizados aceptados internacionalmente como indicadores y pruebas periciales objetivas. FERNÁNDEZ LATORRE, F. M., "Análisis legislativo y jurisprudencial en materia de paisaje y turismo. Implicaciones prácticas", Medio ambiente y derecho. Revista electrónica de derecho ambiental, núm. 20, 2010.

${ }^{101}$ Domènech señala lo siguiente: "El planeamiento urbanístico es un instrumento vigente en todo el ámbito territorial, formulado por la administración local y, por lo tanto, con más potencial que ningún otro para incorporar los procesos de participación ciudadana y la calidad paisajística como atributos inexcusables en la planificación y gestión de todo el territorio y sus ciudades" (DOMĖNECH, "Consideraciones sobre el futuro marco jurídico para la ordenación del paisaje", El paisaje y la gestión del territorio..., cit., p. 425). También Pareja Lozano pone de relieve que el derecho urbanístico ha venido desempeñando un papel trascendental en la protección del paisaje a partir de la concepción sistemática del territorio propia de los instrumentos de planeamiento (PAREJA LOZANO, “Instrumentos legales...", cit., p. 394).
} 
implantación de usos y actividades desde la perspectiva paisajística ${ }^{102}$ —en este sentido, la Estrategia Territorial Europea de 1999 recomienda, como ya hemos apuntado, un uso del planeamiento acorde con la gestión "creativa" de los paisajes culturales como uno de los ejes de la ordenación y gestión del territorio europeo-. Sin olvidar la preeminencia de la variable ambiental sobre la urbanística ${ }^{103}$, a través del planeamiento general pueden establecerse normas de aplicación general y normas reguladoras focalizadas específicamente en la preservación del paisaje. También puede lograrse este objetivo de preservación a través de planes especiales y de instrumentos específicos de paisaje que forman parte del contenido documental de los planes, como los estudios de paisaje y los estudios de integración paisajística recogidos en la Ley valenciana 5/2014, que acompañan al planeamiento urbanístico para orientar los futuros desarrollos urbanos sin malograr los paisajes característicos y la identidad del lugar ${ }^{104}$.

Al formular el planeamiento general, los ayuntamientos se guían por una finalidad de preservación frente a las actuaciones urbanizadoras propias del desarrollo urbano que se puede manifestar en la simple clasificación o ir más allá con medidas de protección del territorio y del paisaje, bien incorporadas directamente en el plan, bien a través de la remisión a planes especiales de protección (STS de 7 de julio de 1997) que deben ser observados, en un segundo nivel, por los proyectos de obras. En este sentido, y como afirma Ferrer Aixalà al analizar las intervenciones en el paisaje urbano: "Los planes urbanísticos establecen directrices físicas y contienen regulaciones normativas. Los proyectos urbanos, arquitectónicos o de elementos urbanos, concretan las formas, las dimensiones y las calidades de los objetos que se añaden a la

\footnotetext{
${ }^{102}$ Téngase en cuenta, además de la legislación urbanística, la normativa sectorial vinculada a esta a los efectos de fijar las determinaciones del planeamiento urbanístico. Así, por ejemplo, el artículo 32 del Decreto-Ley 12/2014, de 7 de octubre, por el que se modifica el Decreto Legislativo 1/2012, de 20 de marzo, por el que se aprueba el texto refundido de la Ley del Comercio Interior de Andalucía, que fija los criterios para el emplazamiento de grandes superficies minoristas por el planeamiento urbanístico, debiendo garantizarse la preservación del paisaje urbano y de sus valores naturales, históricos y artísticos.

${ }^{103}$ Como ha establecido el Tribunal Supremo, el planificador urbanístico no puede contradecir o desconocer las determinaciones contenidas en los planes de ordenación de los recursos naturales (STS de 22 de junio de 2012).

${ }^{104}$ Para un análisis del alcance y contenido de los estudios de paisaje, vid. MUÑOZ CRIADO, A. (dir.), Guía metodológica. Estudios de paisaje, Conselleria de Infraestructuras, Territorio y Medio Ambiente, 2012.
} 
ciudad. El punto de vista del paisaje urbano (es decir, sus criterios, objetivos y voluntades) debe estar implícito en ambos casos"105.

El plan general debe definir los objetivos y criterios ambientales que han de seguir las políticas urbanísticas municipales, de conformidad con los principios y directrices establecidos en la legislación urbanística, entre ellos, la sostenibilidad global del modelo de ordenación, la biodiversidad territorial, el patrimonio natural y la calidad del paisaje. Esta cuestión tendrá evidentemente su reflejo en la evaluación ambiental del plan en el marco de su aprobación urbanística $^{106}$. Así, el informe de sostenibilidad ambiental del plan tiene que contener, entre otras informaciones, la descripción de los aspectos relevantes de la situación actual del medio ambiente y de su probable evolución en caso de que no se aplicara el plan y las características ambientales de las zonas que se pueden ver afectadas significativamente; los problemas ambientales existentes que se consideren trascendentes para el plan, particularmente, los problemas relacionados con las zonas de importancia ambiental y con los espacios naturales protegidos; los objetivos de protección ambiental fijados en el ámbito internacional, europeo, estatal, autonómico o local que tengan relación con el plan, incluidos los objetivos de calidad paisajística que sean aplicables de acuerdo con los catálogos y las directrices del paisaje; y los probables efectos significativos del plan (secundarios, acumulativos, sinergéticos, a corto, medio o largo plazo, permanentes, temporales, positivos y negativos) sobre el medio ambiente, así como la metodología empleada para analizarlos, incluidos aspectos como el patrimonio, la biodiversidad, el patrimonio cultural, el paisaje, etc., y la interrelación entre todos ellos.

\footnotetext{
${ }^{105}$ FERRER AIXALÀ, A., "Paisajes urbanos", Busquets y Cortina, Gestión del... cit., p. 58.

${ }^{106}$ Artículo 17 y ss. de la Ley 21/2013, de 9 de diciembre, de Evaluación Ambiental. Cabe recordar que la Ley 9/2006, de 28 de abril, sobre evaluación de los efectos de determinados planes y programas en el medio ambiente, dispuso que los informes de sostenibilidad ambiental tuvieran en consideración los eventuales efectos de esos instrumentos sobre el paisaje (evaluación ambiental estratégica), lo mismo que el Real Decreto Legislativo 1/2008, de 11 de enero, por el que se aprueba el texto refundido de la Ley de Evaluación de Impacto Ambiental de Proyectos, en relación con la ejecución de proyectos.

Vid. la STC 53/2017, de 11 de mayo, que resuelve el recurso de inconstitucionalidad por vulneración del sistema de distribución de competencias en relación con determinados preceptos de la Ley 21/2013, y el comentario que sobre el pronunciamiento del Tribunal Constitucional realiza Blanca LOZANO CUTANDA en Actualidad Jurídica Ambiental, núm. 71, 2017.
} 
No obstante, son los planes especiales los llamados específicamente a regular aspectos del paisaje. Su función acostumbra a ser la de desarrollar o complementar las determinaciones del planeamiento general, ordenando elementos o aspectos específicos de un ámbito territorial determinado, pero también pueden ordenar aspectos no previstos por aquel.

El plan especial es la figura de planeamiento urbanístico idónea para la ordenación, protección y conservación del patrimonio cultural y natural. La normativa autonómica establece específicamente una tipología de planes especiales para la protección de valores ambientales, paisajísticos, del patrimonio arquitectónico o cultural u otros valores. Entre las diversas finalidades de los planes especiales, la normativa urbanística cita expresamente la de conservar y mejorar el medio natural y el paisaje natural y urbano (así, por ejemplo, el artículo 37 del Decreto Legislativo 1/2000, de 8 de mayo, por el que se aprueba el Texto Refundido de las Leyes de Ordenación del Territorio de Canarias y de Espacios Naturales de Canarias). Como afirma Bassols Coma, estos planes no suponen una categoría ex novo de planeamiento, sino que se encuadran en la categoría general de los planes especiales ${ }^{107}$. Si atendemos a la normativa urbanística, los planes especiales son un instrumento polivalente cuya formulación puede responder a distintas finalidades, entre las que se encuentran la protección del medio rural y del medio natural y la protección de los bienes catalogados. Como ha establecido la jurisprudencia, "tiene una función de contenido diverso dirigida al desarrollo del planeamiento directivo territorial para ordenar sectorialmente un territorio, realizando operaciones urbanísticas específicas o la ejecución material de las determinaciones del Plan General, así como el establecimiento de determinadas medidas de protección con independencia o no de que exista dicho planeamiento" (STSJ de Cataluña de 28 de junio de 2002). Los planes especiales establecen restricciones de usos para ordenar la incidencia y los efectos urbanísticos y ambientales sobre el tejido urbano que las actividades producen o para impedir la desaparición o alteración de los bienes que integran el patrimonio cultural o de las zonas de gran valor agrícola, forestal o ganadero, de espacios

107 BASSOLS COMA, M., "Instrumentos legales de intervención urbanística en los centros y conjuntos históricos", Revista de Derecho Urbanístico, núm. 118, 1990, p. 40. 
rurales o periurbanos o del paisaje. Para ello, les corresponde, entre otras determinaciones, la justificación e identificación de los elementos, ámbitos y valores objeto de protección; el establecimiento de las medidas de protección adecuadas (usos admisibles o incompatibles, actuaciones y obras permitidas y prohibidas sobre los elementos o ámbitos protegidos y parámetros edificatorios de obligado cumplimiento); la regulación y programación de la ejecución de actuaciones de recuperación, rehabilitación o mejora de los elementos, ámbitos o valores objeto de protección; y el establecimiento, si no lo ha hecho el planeamiento general, de los límites relativos al emplazamiento, ocupación de suelo y volumen edificable de las construcciones destinadas a actividades agrarias.

Cuando estos planes urbanísticos se dirijan a la protección de conjuntos y espacios urbanos, deben catalogar los elementos unitarios que los conforman (inmuebles, espacios libres, estructuras, componentes naturales...) y definir los tipos de intervención posibles, fijando los criterios relativos a la conservación de fachadas y cubiertas e instalaciones sobre estas. Entre los criterios generales de ordenación e integración paisajística que el planificador debe tener en cuenta, pueden citarse la necesaria integración de los crecimientos urbanos en la morfología del territorio y del paisaje, definiendo adecuadamente los bordes y la silueta urbana y preservando la singularidad paisajística y la identidad visual del lugar, así como la adopción de determinaciones para el control de los elementos con incidencia en la calidad del paisaje urbano, garantizando el mantenimiento de las principales vistas y perspectivas existentes (art. 8 de la Ley valenciana 5/2015). Se prevé, además, que, con carácter excepcional, estos planes de protección puedan permitir operaciones de remodelación urbana cuando impliquen la mejora de sus relaciones con el entorno territorial o urbano o cuando eviten los usos degradantes para el propio conjunto. Por añadidura, deben mantener la estructura urbana y arquitectónica del conjunto y las características generales del ambiente y de la silueta paisajística. Por este motivo, no se permiten alineaciones nuevas, alteraciones en la edificabilidad, parcelaciones ni agregaciones de inmuebles, salvo que contribuyan a la mejor conservación general del conjunto. 
El plan especial puede resultar el instrumento más adecuado para la protección paisajística tanto en la ciudad consolidada como en el ámbito rural, pero también los nuevos desarrollos urbanos deben observar algunas prescripciones al respecto. Los planes parciales urbanísticos —en terminología de la vieja legislación estatal de suelo, que aún perdura en la mayoría de normativas autonómicas - deben dar cumplimiento a las determinaciones vinculantes de la memoria ambiental, que evaluará si la ejecución del plan incide negativamente en el paisaje. Ello implica la previsión de medidas correctoras que eviten o mitiguen la incidencia negativa en el paisaje de la ejecución del plan y permitan una correcta integración de la nueva urbanización y edificación en el entorno (adecuada distribución de las viviendas en el ámbito de actuación, incorporación de elementos ornamentales, acabados y colores, etc.). La falta de adecuación del plan parcial a las exigencias legales en materia paisajística comporta su nulidad por considerarse la actuación urbanística contraria a derecho. Un ejemplo ilustrativo lo constituye la anulación del acuerdo plenario del Ayuntamiento de Sanxenxo (Galicia) por el cual se aprobaba definitivamente el plan parcial que proyectaba la construcción de más de un millar de viviendas en el municipio, sobre la base del desconocimiento del valor medioambiental de la zona y de su interés forestal y paisajístico ${ }^{108}$.

\section{e) Los catálogos de protección}

\footnotetext{
${ }^{108}$ La STS de 29 de junio de 2016 ratifica la Sentencia de 5 de febrero de 2015 de la Sala de lo Contencioso-Administrativo del Tribunal Superior de Justicia de Galicia, que anuló el Plan Parcial de Desarrollo del Suelo Urbanizable núm. 14 en Monte Faro: "Así, es de reiterar que la sentencia, en este concreto punto, señala que: '...En el mencionado anexo se indica que la homogeneización de la edificación, que es una de las causas a la que la Memoria atribuye la afectación negativa a la integración en el paisaje, se solventará con pequeños elementos ornamentales o la incorporación de acabados y colores que ayuden a la integración paisajística. Pero sobre las otras causas —distribución de las viviendas en hileras continuas y la falta de fragmentación del volumen edificado- lo que se hace es negar el efecto negativo que la Memoria considera se producirá, incorporando unos planos de perfiles visuales desde los núcleos más próximos para tratar de desvirtuar lo que en aquella se dice sobre la incidencia sobre el paisaje. Por ello tiene que ser aceptada la alegación de la parte actora de que, en cuanto a la integración en el paisaje, el plan parcial aprobado no da cumplimiento a las determinaciones vinculantes de la Memoria ambiental, lo que determina la disconformidad a derecho del acuerdo municipal que le dio aprobación definitiva, por lo que ha de ser anulado, con la consiguiente estimación del recurso [...]"'.
} 
Los bienes del patrimonio cultural y natural protegidos de acuerdo con la legislación sectorial deben incluirse en un catálogo, un instrumento urbanístico que abarca todo el término municipal y que determina los espacios, monumentos o inmuebles que requieren un régimen específico de preservación por razón de sus especiales valores culturales, naturales, paisajísticos, históricos, arquitectónicos, arqueológicos, artísticos, geológicos, etc., con determinación del grado de protección que les corresponda y los tipos de intervención permitidos en cada supuesto ${ }^{109}$. Los bienes que forman parte del catálogo pueden ser objeto de protección a título individual o como parte de un conjunto.

Los ayuntamientos deben aprobar y mantener actualizado el catálogo municipal, cuya función no es otra que conseguir la efectividad de las medidas urbanísticas de protección referidas a los concretos bienes inmuebles, singulares o de conjunto (monumentos, edificios, jardines, paisajes, bienes culturales), que se catalogan, aunque también pueden contener medidas cautelares de protección o de fomento y puesta en valor. Los catálogos podrán elaborarse como instrumentos autónomos o, más habitualmente, como documentos integrantes de instrumentos de ordenación territorial y urbanística - ya sea planeamiento general o planeamiento derivado entre cuyos fines se establezca la conservación de los bienes objeto de catalogación-.

El catálogo identifica, mediante el correspondiente inventario, los bienes sobre los que recae algún tipo de protección derivada de la legislación del patrimonio cultural, del patrimonio natural y del paisaje. El catálogo ofrece información física y jurídica sobre tales bienes y establece el grado de protección al que están sujetos y los tipos de intervenciones o actuaciones posibles ${ }^{110}$. Más

\footnotetext{
${ }^{109}$ Vid. ALONSO IBÁÑEZ, M. R., Los Catálogos Urbanísticos y otros Catálogos Protectores del Patrimonio Cultural Inmueble, Ed. Aranzadi, Madrid, 2005.

${ }^{110}$ Los criterios de catalogación establecidos en la memoria explicativa y justificativa del plan urbanístico son previos a la decisión de catalogación propiamente dicha y han de ser respetados por aquel en el momento de redactar la lista de bienes a conservar (SSTS de 24 de octubre de 1990, 27 de abril de 2004 y 15 de noviembre de 2012). Como establece la sentencia citada de 2004: "[...] tales criterios para la catalogación los ha fijado el propio Ayuntamiento en la memoria del Catálogo, razón por la que el Tribunal de instancia razona con perfecta lógica al afirmar en el párrafo primero del fundamento jurídico sexto de la sentencia recurrida que 'en la elaboración de los criterios generales de catalogación opera la discrecionalidad, pero, una vez elegidos los
} 
concretamente, dicho documento contiene las fichas individualizadas de los bienes catalogados, en las que se establece su identificación, emplazamiento, descripción, niveles de protección y uso, actuaciones previstas y normativa aplicable a la situación y descripción general de los bienes protegidos, los criterios de valoración y selección. Si el planeamiento general prevé expresamente la formulación de un plan especial urbanístico de protección del patrimonio arquitectónico o cultural, el catálogo puede limitarse a enumerar e identificar los bienes inmuebles objeto de protección ${ }^{111}$.

\section{f) Régimen de intervención urbanística en el suelo no urbanizable}

También en la clasificación del suelo no urbanizable mediante el planeamiento general $-\mathrm{y}$, si procede, su concreción mediante planeamiento especialdeben establecerse directrices vinculadas al paisaje, directrices que no solo deben perseguir la preservación del paisaje, sino también, como hemos visto a lo largo de este trabajo, su desarrollo sostenible, sometiéndose a las medidas correctoras que se consideren pertinentes a fin de reducir los efectos de las construcciones y la desnaturalización de los espacios rurales ${ }^{112}$. Cabe apuntar que tradicionalmente la responsabilidad de conservar y proteger los espacios naturales y rurales ha recaído en la Administración; sin embargo, con el tiempo los propietarios y otros agentes sociales se han implicado, mediante diversas

criterios de catalogación, las concretas catalogaciones han de resultar coherentes con la decisión inicial, que opera como límite"'.

${ }^{111}$ El catálogo está formado por distintos documentos: memoria descriptiva y justificativa de los criterios de catalogación seguidos, estudios complementarios, planos de información, ficha individualizada de cada elemento catalogado - con expresión de los datos identificativos del inmueble, nivel de protección asignado, descripción de sus características constructivas, estado de conservación, medidas para su conservación, rehabilitación y protección y uso actual-, plano de situación del bien o espacio catalogado y fotografías descriptivas y normativa reguladora. Estos catálogos identifican y determinan los tipos de intervención posible y el régimen de protección especial de determinados elementos inmuebles o espacios naturales que merezcan una valoración cultural y social relevante. El nivel de protección puede ser distinto en función de los bienes incluidos en el catálogo correspondiente (integral, parcial...). Téngase en cuenta que la catalogación o inventario de bienes en sí mismos no implican ningún grado de protección para dichos bienes, sino que es el plan urbanístico que incluye el catálogo el que se la proporciona.

${ }^{112}$ Ciertas actuaciones en suelo no urbanizable requieren la aprobación de un plan especial, cuyo contenido documental ha de contar con un estudio de impacto e integración paisajística, con una diagnosis del impacto y de las medidas correctoras que se proponen. 
estrategias e instrumentos, en la conservación de la naturaleza y el paisaje (custodia del territorio o land stewardship) ${ }^{113}$.

La clasificación urbanística que afecta al suelo no urbanizable (o la denominación usada por la normativa urbanística autonómica: rústico, rural...) es susceptible de división en dos tipologías en atención a la presencia de patrones valorativos relevantes. Así, el planeamiento general distingue entre suelo de régimen común y suelo de protección especial; este último responde a la concurrencia de determinados valores (ambientales, paisajísticos, culturales, históricos, económicos) o a la aplicación de criterios previstos en la normativa sectorial, en cuyo caso la clasificación o reclasificación de suelo no tiene carácter discrecional sino reglado, resultando obligada la protección de este suelo (STS de 14 de febrero de 2007) ${ }^{114}$. La STS de 10 de julio de 2012 declaró que "el carácter sostenible y medioambiental del urbanismo actual se proyecta, de forma más directa y efectiva, en relación con los suelos rústicos en que concurren especiales valores de carácter ambiental". Sin embargo, no olvidemos que el Convenio del Paisaje involucra igualmente en los mecanismos de protección y gestión a los paisajes ordinarios o corrientes, de modo que el suelo no urbanizable común también es objeto de determinaciones sobre integración paisajística, como las relativas al régimen de usos permitidos y sus intensidades, superficies mínimas indivisibles, prohibición de parcelación urbanística y edificación incontrolada, alturas máximas, ocupación máxima de parcela y otras determinaciones análogas. En los espacios que atesoran una evidente calidad paisajística, el planeamiento general establecerá el mismo tipo de determinaciones, pero con parámetros más restrictivos en cuanto a usos, obras, instalaciones y actividades a implantar en estos suelos, pudiendo llegarse a la prohibición de construir. Las normativas urbanísticas autonómicas exigen la compatibilidad de estas intervenciones en suelo no urbanizable con el mantenimiento, conservación y mejora de los recursos protegidos, y establecen

${ }^{113}$ PIETX, J. y BASORA, X., "La custòdia del territori: un nou instrument de concertació basat en la implicació ciutadana per a conservar el paisatge", Observatori del Paisatge, Ordenació $i$ gestió del paisatge a Europa, Plecs de Paisatge Eines, 2, Observatori del Paisatge, Olot, 2009, p. 299 y ss.

${ }^{114}$ El Tribunal Supremo determina que la reclasificación de un suelo no urbanizable a no urbanizable de especial protección es ajustada a derecho en atención al valor paisajístico y arqueológico de las tierras incluidas en la finca, por lo que se desestima la demanda. En el mismo sentido, la STS de 22 de junio de 2012. 
las medidas y acciones necesarias para prevenir, reducir y compensar el impacto significativo en el medio ambiente que pueda derivarse de la ejecución del plan. Por ello, los correspondientes instrumentos de evaluación de impacto ambiental y los estudios de integración paisajística constituyen un poderoso aliado para prevenir y mitigar las consecuencias de las actividades antrópicas en el paisaje, sin olvidar el papel complementario que juega la legislación fiscal respecto de las actividades con impacto paisajístico ${ }^{115}$.

Así, en Cataluña (artículos 47 a 50 del Decreto Legislativo 1/2010, de 3 de agosto, por el que se aprueba el texto refundido de la Ley de Urbanismo) ${ }^{116}$ se admite la reconstrucción y rehabilitación de viviendas y otras construcciones rurales para contribuir a la conservación y recuperación del patrimonio rural y para incentivar la actividad económica y el desarrollo del entorno rural. Dicha reconstrucción y rehabilitación se condiciona a la existencia de valores arquitectónicos, históricos, ambientales, paisajísticos ${ }^{117}$ y sociales. También se prevé, como supuesto singular, la rehabilitación de construcciones rurales en desuso con objeto de corregir el impacto ambiental o paisajístico negativo. EI logro de este objetivo puede comportar que, en el marco de las tareas de rehabilitación, se reduzca el volumen preexistente de la construcción. Es usual que estas masías o casas rurales susceptibles de ser reconstruidas o rehabilitadas formen parte del catálogo de bienes protegidos del planeamiento

\footnotetext{
${ }^{115}$ El Tribunal Supremo ha señalado que la imposición de un tributo por parte de la Comunidad Autónoma extremeña que no grava el ejercicio de una actividad económica en sí misma considerada (el transporte y distribución de energía eléctrica utilizando tendidos de media y alta tensión) sino la incidencia medioambiental de esos tendidos es conforme a derecho: "En otras palabras y, por lo que en este recurso de casación interesa, las personas físicas o jurídicas que transportan y distribuyen energía eléctrica utilizando tendidos de media y alta tensión, por el efecto que los elementos fijos de esos tendidos tienen en el paisaje, con el desarrollo de su actividad inciden, alteran o ponen en riesgo el medio ambiente. Tan es así, que la base imponible y la cuota tributaria nada tienen que ver con los rendimientos económicos derivados del ejercicio de la actividad. Además, su finalidad extrafiscal se confirma a la vista de la íntegra afección de los ingresos recaudados a la financiación de medidas y programas de carácter medioambiental" (STS de 14 de noviembre de 2016). Tampoco se cuestiona el impuesto riojano sobre el impacto visual producido por los elementos de suministro de energía eléctrica y elementos fijos de redes de comunicaciones telefónicas (STS de 27 de abril de 2016).

${ }^{116} \mathrm{Vid}$. DEPARTAMENT DE TERRITORI I SOSTENIBILITAT, Criteris per a la correcta integració en el paisatge de les construccions aïllades en sòl no urbanitzable, Generalitat de Catalunya, Barcelona, 2013. En este documento se desarrollan y complementan las determinaciones de los planes territoriales relativas a la integración paisajística de estas construcciones.

${ }_{117}$ Por ejemplo, si las edificaciones conforman un paisaje concreto humanizado o no, con valor reconocido y caracterizando la imagen propia de un territorio determinado por razones de su exposición y unidad con el entorno que puede formar parte de un recorrido paisajístico.
} 
general, a la vez que pueden ser declaradas bienes de interés local o nacional en aplicación de la Ley 9/1993, de 30 de septiembre, del Patrimonio Cultural Catalán, y del Decreto 78/2002, de 5 de marzo, por el que se aprueba el Reglamento de Protección del Patrimonio Arqueológico y Paleontológico. Asimismo, también son motivos de inclusión en el catálogo las determinaciones en este sentido del planeamiento territorial, urbanístico y sectorial y de los catálogos del paisaje ${ }^{118}$.

En cualquier caso, la reconstrucción y la rehabilitación del patrimonio arquitectónico rural tienen que respetar el volumen edificado preexistente y la composición volumétrica original. Sin embargo, el planeamiento puede admitir ampliaciones o nuevas construcciones auxiliares siempre que no afecten a los valores arquitectónicos y paisajísticos concurrentes y queden justificadas por razón del desarrollo de los usos admitidos. Por último, las construcciones rurales en desuso pueden experimentar una disminución de su volumetría si es necesario para corregir el impacto ambiental o paisajístico negativo.

\section{Para concluir: la valorización del paisaje y de los bienes que son parte integrante de este}

El paisaje ha constituido desde siempre una pieza clave —aunque intangiblede la ordenación del territorio, incluso antes de lograr sustantivación jurídica propia $^{119}$. No obstante, la ratificación por España del Convenio Europeo del Paisaje, hace una década, ha permitido avanzar significativamente en la concepción legal de este recurso, antaño focalizado exclusivamente en los

\footnotetext{
${ }^{118}$ Una cuestión que en estos años ha suscitado cierta inquietud a nivel municipal ha sido el hecho de si se podían incluir en el catálogo construcciones localizadas en suelo no urbanizable cuando los restos edificados fueran prácticamente inexistentes. Es muy habitual que en los municipios rurales existan ruinas de lo que en su tiempo fueron masías o casas rurales y se desee integrarlas en el catálogo. Si bien la normativa urbanística no dice nada al respecto, la Generalitat ha considerado que no son recuperables si están situadas en espacios de riesgo reconocido o en lugares donde los valores ecológicos y paisajísticos prevalecen sobre la construcción arquitectónica.

${ }^{119}$ Con todo, las primeras etapas de desarrollo de las políticas paisajísticas se caracterizaron por un tratamiento legal de marcado carácter proteccionista sobre la base de una concepción estética y cultural del paisaje. Para un análisis en profundidad de la evolución de las políticas de paisaje, vid. FROLOVA, M., "La evolución reciente de las políticas de paisaje en España y el convenio europeo del paisaje", Proyección, núm. 6, 2009.
} 
aspectos patrimoniales, visuales y estéticos. La jurisprudencia ha hecho hincapié en la dualidad espacial y temporal del paisaje y en su carácter dinámico, habida cuenta de la carga de subjetividad que encierra su definición, que lleva implícita de forma inequívoca un juicio de valor ("cualquier parte del territorio tal como la percibe la población"). El mencionado Convenio incorpora un concepto más amplio y evolucionado de paisaje en el que este se nos presenta como una seña de identidad cultural — sin anudarlo exclusivamente a la belleza o excepcionalidad del lugar- que contribuye a la confluencia e integración de los valores naturales y culturales en un mismo espacio.

El Convenio Europeo del Paisaje ha contribuido sobremanera a trastocar la tradicional idea del paisaje como espacio idealizado al dotarlo de un carácter universal ("el paisaje es un elemento importante de la calidad de vida de las poblaciones en todas partes: en los medios urbanos y rurales, en las zonas degradadas y de gran calidad, en los espacios de reconocida belleza excepcional y en los más cotidianos"). Por mor de la nueva filosofía, se ha ido abandonando definitivamente el concepto elitista del paisaje —como espacio susceptible de protección solo si atesora un interés singular o excepcional-, habida cuenta de que los espacios ordinarios o banales también se consideran dignos de protección debido a su significación y valor para el conjunto de la sociedad. De forma que, a día de hoy, resulta imposible autorizar en ellos la implantación de cualesquiera usos, actividades e infraestructuras si no resultan compatibles con la conservación y mejora de sus valores ambientales, culturales y paisajísticos, una idea que se proyecta singularmente en el ámbito urbanístico por mor de la inserción en los planes de los instrumentos de análisis del paisaje y las evaluaciones ambientales. Asimismo, la normativa vigente ha adoptado un enfoque holístico en el que el tratamiento jurídico del patrimonio paisajístico va indefectiblemente de la mano de las políticas ambientales y de ordenación territorial y urbanística, en cuya regulación se integra — de forma más o menos coherente y sistematizada, dependiendo de cada comunidad autónoma-. Pero seguramente la contribución más destacada ha sido el salto cualitativo consistente en superar la clásica finalidad protectora de los valores del paisaje derivados de su configuración natural o de la acción del ser humano para emprender una cruzada aglutinadora de fines más ambiciosos que se 
fundamenta en la creciente importancia del paisaje como instrumento de ordenación territorial. Mediante la formulación de objetivos de calidad paisajística y su integración en planes de ordenación territorial y urbanística, las políticas de paisaje aspiran a conseguir objetivos más ambiciosos, como el mantenimiento regular del paisaje en el marco de los procesos de transformación urbana y la mejora, restauración y creación paisajística en los ámbitos urbano, periurbano y rural, así como la articulación armónica de todos ellos. La puesta en valor del paisaje como factor económico diferenciador y como recurso turístico es indudablemente otro de los fines de las políticas de paisaje.

Poco antes o en el mismo momento del colapso del modelo inmobiliario de 2007, el Estado y las comunidades autónomas empezaron a introducir el principio rector del desarrollo urbanístico sostenible en sus ordenamientos urbanísticos para dotar la ordenación de los usos del suelo de una dimensión medioambiental. Esa sostenibilidad urbanística se logra a través de la armonización y el ajuste de las necesidades de crecimiento con la preservación de los recursos naturales (en especial, del suelo) y de los valores paisajísticos, arqueológicos, históricos y culturales en beneficio de la seguridad y el bienestar de las generaciones presentes y futuras. Las finalidades nucleares que derivan del principio de desarrollo sostenible son, por una parte, la utilización del suelo en atención a su carácter de recurso natural no renovable y, por otra, la protección y gestión cuidadosa del medio ambiente y del patrimonio natural, preservando las funciones ecológicas del suelo, la mejora de la calidad ambiental, la gestión adecuada del paisaje para proteger los valores, la utilización racional de los recursos naturales y el fomento de la eficacia energética. El suelo es un recurso económico, pero, al mismo tiempo, un recurso escaso y no renovable. En este sentido, y en coherencia con el principio de sostenibilidad, la legislación urbanística autonómica estableció directrices sostenibles para la formulación y ejecución del planeamiento con el fin de asumir una ordenación con la que lograr unos niveles adecuados de calidad de vida y de sostenibilidad ambiental. Esas directrices, con el contenido adecuado a sus necesidades, también se implementan en el tejido urbano con objeto de compatibilizar las construcciones, edificaciones y actividades propias 
del lugar con la protección, el mantenimiento y la mejora de los valores del paisaje urbano y de la imagen de la ciudad ${ }^{120}$.

Esta protección de espacios o partes del territorio - con o sin valores específicos concurrentes - ha supuesto la toma de contacto del derecho nacional con el paisaje, pero la etapa en que la finalidad exclusiva de las legislaciones (ambiental, urbanística, patrimonio) era proteccionista ha sido superada merced a la influencia del Convenio Europeo del Paisaje, para dar paso a una asunción de responsabilidades más ambiciosas de los poderes públicos para con este patrimonio - ya sea natural, rural o urbano- que se amplían a su ordenación y gestión. En este nuevo marco, el paisaje se considera un recurso provechoso y lucrativo y, en consecuencia, no es extraño que los tribunales se pronuncien a día de hoy en favor de la indemnizabilidad de los daños irrogados al paisaje del que disfruta un particular (el denominado "paisaje privado") en concepto de minoración del valor de la propiedad o de demérito de esta ${ }^{121}$. La necesidad de valorizar el patrimonio paisajístico se hace perceptible no solo en los ámbitos cultural y urbanístico — seguramente los más evidentes-, sino también en numerosos sectores en atención a las consideraciones de tipo ambiental, económico, social, histórico y arquitectónico

\footnotetext{
${ }^{120}$ A nivel urbanístico, la regulación del paisaje urbano se vehicula mediante ordenanzas municipales que abordan, de forma integral o separadamente, cuestiones relativas a publicidad exterior, terrazas y quioscos, señalización y rotulación de vías y protección lumínica, entre otras. Barcelona, Zaragoza, Córdoba, Oviedo, Granada, Murcia y La Coruña son algunas de las localidades que han dictado normativa al respecto. Así, por ejemplo, la Ordenanza de Usos del Paisaje Urbano de la ciudad de Barcelona establece en su exposición de motivos lo siguiente: "Son elementos del paisaje urbano los espacios públicos, las construcciones (sobre todo las que integran el patrimonio cultural), los espacios libres de edificación -edificables o no- y el espacio aéreo. Los agentes contaminantes de estos elementos son los que afectan, sobre todo, a la percepción visual, estética y de seguridad (fachadas de edificios, publicidad, antenas, toldos y cualquier otra instalación accesoria a las construcciones o en el resto de elementos del paisaje urbano)". Precisamente, la cuestión relativa a la instalación de antenas y redes de telecomunicación está estrechamente vinculada a los usos del paisaje urbano, dando lugar a diversos pronunciamientos del Tribunal Supremo. En la STS de 24 de marzo de 2012, el Tribunal considera acertada la obligación impuesta a diversas operadoras de compartir el emplazamiento de las instalaciones radioeléctricas siempre que lo requieran los intereses medioambientales o urbanísticos que los ayuntamientos deben proteger.

${ }^{121}$ El Tribunal Supremo considera indemnizables por la vía del justiprecio los daños ocasionados al paisaje a causa del ejercicio de la potestad expropiatoria, siempre que se den ciertos requisitos (entre ellos, que exista una residencia desde la que apreciar ese paisaje). La indemnización también puede derivarse de la existencia de responsabilidad patrimonial de las administraciones por causa de daños al paisaje privado como consecuencia de expropiaciones o de ejecución de obras en fincas anexas a la del perjudicado o de construcción de obra pública. SÁNCHEZ SÁEZ, A. J., "La indemnización de los daños ocasionados en el paisaje como consecuencia de expropiaciones forzosas y de la ejecución de obras públicas", Revista de Administración Pública, núm. 189, 2012, pp. 245-287.
} 
que deben ser atendidas. De tal manera que el paisaje puede convertirse en un indicador de calidad territorial y, en consecuencia, en un activo de competitividad económica, constituyendo un poderoso factor de contribución al crecimiento económico y a la creación de empleo. Un ejemplo de ello es la importancia que se da al patrimonio arquitectónico en las operaciones de regeneración y renovación urbanas, focalizando su uso en el fomento del turismo cultural, o en el turismo rural, si de paisaje rural se trata. De ahí los debates actuales en torno a la idea del patrimonio cultural-natural-paisajístico como bien de mercado (como recurso económico de naturaleza productiva), además de su ya reconocida configuración como bien común. En cualquier caso, la gestión y valoración del paisaje deben instrumentalizarse de forma que no se dañe su condición de bien explotable y su potencialidad como producto final del que los consumidores pueden hacer uso ${ }^{122}$.

El 17 de mayo de 2017, el Parlamento Europeo y el Consejo de la Unión Europea aprobaron la Decisión por la que se establece la declaración del Año Europeo del Patrimonio Cultural 2018, con el objetivo de fomentar el intercambio y la valoración del patrimonio cultural de Europa como un recurso compartido y de reforzar el sentimiento de pertenencia a un espacio común europeo. Evidentemente, la protección del patrimonio es un paso importante a los efectos de su conservación y preservación, pero no es suficiente. La acción de las administraciones públicas debe fomentar la incorporación de los bienes del patrimonio cultural a usos activos $-\mathrm{y}$ adecuados a su naturaleza- como medio de promover el interés social hacia ellos. En esta línea, muchos planes especiales van más allá de la simple conservación física de espacios e incentivan la recuperación residencial del área y de las actividades económicas tradicionales, propiciando, con iniciativas creativas, la atracción turística y económica de la zona, con fundamento en la existencia de un patrimonio que hay que valorizar.

${ }^{122}$ ZUBELZU MíNGUEZ, S. y ALLENDE ÁLVAREZ, F., "El concepto de paisaje y sus elementos constituyentes: requisitos para la adecuada gestión del recurso y adaptación de los instrumentos legales en España", Cuadernos de Geografía, vol. 24, núm. 1, 2015, p. 32. 
Por todo ello, puede afirmarse que el paisaje desempeña una función social relevante por su aportación al desarrollo social y económico y por su estrecha vinculación con la salud y el bienestar de las personas, de forma que la Ley de Patrimonio Histórico reconoce que las actividades encaminadas a la consecución de su protección y conservación pueden ser declaradas de utilidad pública o interés social, por ejemplo a efectos expropiatorios.

En los últimos tiempos, la gestión urbanística del patrimonio cultural y natural ${ }^{123}$ ha actualizado su perfil para adoptar nuevos objetivos centrados en promocionar y divulgar su valor, a la vez que se conciencia de la fragilidad de este patrimonio y la necesidad de su preservación (creatividad en la implementación de programas que buscan rentabilizar la cultura). Los nuevos modelos de gestión del patrimonio cultural dan cuenta de las potencialidades del paisaje para cohesionar socialmente, para atraer inversiones (la cultura como motor del desarrollo económico) y para vertebrar el territorio. Estos modelos tienden a una gestión más flexible, consecuencia de la entrada de la iniciativa privada y de tener en cuenta las necesidades de los residentes, mediante mecanismos de incentivación de la participación ciudadana.

El convencimiento de que la cultura puede actuar como catalizador de riqueza y desarrollo local ha contribuido a dar mayor visibilidad a los bienes integrantes del patrimonio arquitectónico y natural. La planificación estratégica es uno de los instrumentos que sirven al fin de valorizar el patrimonio en términos de eficiencia económica y social, en la medida que conecta los distintos ámbitos y sectores de la cultura para obtener una perspectiva integral. Los planes estratégicos de cultura ${ }^{124}$ surgen fruto del consenso entre los distintos actores que intervienen en el desarrollo cultural de la ciudad y establecen las líneas estratégicas de futuro para la ciudad en el ámbito cultural. En un contexto de

\footnotetext{
${ }^{123}$ Sobre la valorización del patrimonio natural y su conversión en producto de consumo ("el turista urbano está más interesado en visitar bosques y montañas salvajes que campos de algodón o maíz", p. 70), vid. VACCARO, I. y BELTRAN, O., "Turning nature into collective heritage: The social framework of the process of patrimonialization of nature", Roigé, X. y Frigolé, J. (eds.), Constructing cultural and natural heritage. Parks, Museums and Rural Heritage, ICRPC, Girona, 2010, p. 68 y ss.

${ }^{124}$ Vid. MANITO, F., Planificación estratégica de la cultura en España, Iberautor Promociones Culturales, Barcelona, 2008.
} 
creciente competencia entre ciudades por captar recursos y proyección internacional $^{125}$, el paisaje constituye un factor de atracción que no debe menospreciarse. El Plan Estratégico de Cultura de Barcelona (2006) apunta al respecto lo siguiente: "Dado que una parte muy importante del atractivo de Barcelona se basa en su oferta cultural (entendida en un sentido amplio, que incluiría tanto los equipamientos culturales de la ciudad como el patrimonio tangible e intangible, y donde los espacios públicos desarrollan un papel muy relevante), parece necesario considerar la importancia de una mirada cultural, desde el sector cultural de Barcelona, para el análisis y la propuesta de soluciones para estos retos [...]. Hoy es indiscutible que, de manera directa e indirecta, las actividades culturales son generadoras de valor añadido y creadoras de ocupación [...]. La visión del nuevo Plan apela a la dimensión cultural del desarrollo. Parte de la constatación de que el desarrollo de un territorio no sólo lo conforman el crecimiento económico, una justa distribución de la riqueza y la sostenibilidad ambiental, sino que también se sostiene en el desarrollo cultural. La importancia de esta constatación reside en la consideración de la cultura no como un instrumento, sino como una dimensión del desarrollo"126. Los planes estratégicos se ocupan del patrimonio cultural (monumentos, paisajes) en cuanto parte integrante del concepto de cultura. Desde esta perspectiva, el planificador puede optar por dar a este patrimonio un tratamiento propio, esto es, ocuparse del incremento y recuperación de espacios para el desarrollo de actividades culturales en sí mismos considerados — visión del patrimonio cultural como un elemento aislado que debe ser objeto de tutela y protección, en línea con la normativa de patrimonio protegido-, o bien considerarlo como un recurso cultural más con el que potenciar y rentabilizar la oferta de actividades que ofrece la ciudad. La atracción del turismo, mediante la oferta de nuevos servicios y productos de consumo cultural, se convierte así en uno de los objetivos principales del uso

\footnotetext{
${ }^{125}$ Como sostienen Manero Miguel y García Cuesta, "la proyección competitiva de un territorio, en lo que tiene de acreditación de un prestigio, de una imagen, de una localización y de unos valores dignos de ser reconocidos, tiene mucho que ver con la relevancia de su Patrimonio, con la calidad de los elementos tangibles e intangibles, materiales e inmateriales que lo integran y con las prácticas aplicadas a las diferentes modalidades de salvaguarda y gestión", MANERO MIGUEL, F. y GARCíA CUESTA, J. L. (coords.), Patrimonio cultural y desarrollo territorial, Thomson Reuters Aranzadi, Cizur Menor, 2016, p. 19.

${ }^{126}$ AYUNTAMIENTO DE BARCELONA, Plan Estratégico de Cultura de Barcelona. Nuevos acentos 2006, noviembre de 2006, Barcelona, pp. 14, 15 y 20.
} 
del patrimonio urbano y natural, en este último caso mediante una gestión sostenible de los paisajes y el establecimiento de servicios y actividades económicas compatibles con la naturaleza rústica del entorno.

Otro ejemplo de esta estrategia encaminada a proyectar el valor artístico, histórico, educativo, social, estético, etc., del paisaje como patrimonio cultural buscándole un aprovechamiento productivo es la creación de clústeres culturales. Muchas ciudades españolas y europeas han utilizado esta iniciativa, basada en la concentración de empresas y negocios cuyo campo de acción es la gestión de bienes culturales, para crear o rediseñar una imagen identitaria, una marca de la ciudad basada en la cultura y el patrimonio vinculado a esta ${ }^{127}$.

\section{Bibliografía}

AGENCIA EUROPEA DEL MEDIO AMBIENTE-OFMA, Fragmentación del paisaje en Europa, Gobierno de España, Madrid, 2013.

ALLI TURRILLAS, Juan Cruz, La protección de la biodiversidad. Estudio jurídico de los sistemas para la salvaguarda de las especies naturales y sus ecosistemas, Dykinson, Madrid, 2016.

ALONSO IBÁÑEZ, María Rosario, Los Catálogos Urbanísticos y otros Catálogos Protectores del Patrimonio Cultural Inmueble, Editorial Aranzadi, Madrid, 2005.

ALVES CORREIA, Fernando y ALMEIDA AZEVEDO, Bernardo, "O regime jurídico de protecção e valorização do património cultural em Portugal”, López Ramón, Fernando (coord.), El patrimonio cultural en Europa y Latinoamérica, INAP, Madrid, 2017.

ASCÓN BORRÀS, Rosa et al., "La formación de expertos en gestión del paisaje", Busquets, Jaume y Cortina, Albert, Gestión del paisaje, Ariel, Barcelona, 2009.

\footnotetext{
${ }^{127}$ Vid., entre otros, BALLART HERNÁNDEZ, J. y JUAN I TRESSERRAS, J., Gestión Cultural. Estrategias para la programación territorial y la gestión de recursos, Federación Andaluza de Municipios y Provincias, Sevilla, 2000; BONET, LI., CASTAÑER, X. y FONT, J. (eds.), Gestión de proyectos culturales. Análisis de casos, Ariel, Barcelona, 2001; CUADRADO, M. y BeRENGUER, G., El Consumo de Servicios Culturales, ESIC, Madrid, 2002; ROSELLÓ CEREZUELA, D., Diseño y evaluación de proyectos culturales, Ariel, Barcelona, 2004.
} 
AYUNTAMIENTO DE BARCELONA, Plan Estratégico de Cultura de Barcelona. Nuevos acentos 2006, noviembre de 2006.

BALLART HERNÁNDEZ, Josep y JUAN I TRESSERRAS, Jordi, Gestión del patrimonio cultural, Ariel, Barcelona, 2001.

BASSOLS COMA, Martín, "Instrumentos legales de intervención urbanística en los centros y conjuntos históricos", Revista de Derecho Urbanístico, núm. 118, 1990.

BEN, Luis y GONZÁLEZ, Antonio Javier, Gestión Cultural. Estrategias para la programación territorial y la gestión de recursos, Federación Andaluza de Municipios y Provincias, Sevilla, 2000.

BERMEJO LATRE, José Luis, "La indeterminación y amplitud del concepto de expolio del patrimonio cultural español”, López Ramón, Fernando (coord.), El patrimonio cultural en Europa y Latinoamérica, INAP, Madrid, 2017.

BONET, Lluís, CASTAÑER, Xavier y FONT, Josep (eds.), Gestión de proyectos culturales. Análisis de casos, Ariel, Barcelona, 2001.

BROCHOT, Aline, "The Paradoxes of Policy: Governance and Conflicts in Three Cultural World Heritage Landscapes", Luginbühl, Yves, Howard, Peter y Terrasson, Daniel (eds.), Landscape and Sustainable Development. The French Perspective, Ashgate, Dorchester, 2015.

BRONNIN, Sara, "Report for the United States", XI International Urban Law Congress, Architectural Heritage, Sites and Landscapes Seized by Urban Law, Barcelona, septiembre de 2017.

CAMPAGNE, D. M., HERNÁNDEZ HERNÁNDEZ, M. y CANTÓ LÓPEZ, T., "El paisaje y las vallas publicitarias: tensiones jurídico-ambientales", Revista Aranzadi de Derecho Ambiental, núm. 9, 2006.

CARBALLEIRA RIVERA, María Teresa, "El paisaje como bien cultural", Fernández Torres, Juan Ramón, Prieto de Pedro, Jesús y Trayter Jiménez, Joan Manuel (coords.), El camino de Santiago y otros itinerarios. Cultura, historia, patrimonio, urbanismo, turismo, ocio y medio ambiente. Liber Amicorum Enrique Gómez-Reino Carnota, Tirant lo Blanch-Escola Galega de Administración Pública, Valencia, 2014.

CARTEI, Gian Franco, "Autonomia locale e pianificazione del paesaggio", Rivista trimestrale di diritto pubblico, 3, 2013. 
CORTINA, Albert y QUERALT, Arnau, "La regulación específica del paisaje en la legislación autonómica", Ministerio de Medio Ambiente, Convenio Europeo del Paisaje. Textos y comentarios, Gobierno de España, Madrid, 2007.

CORTINA, Albert, "La ley de protección, gestión y ordenación del paisaje de Cataluña", El paisaje y la gestión del territorio. Criterios paisajísticos en la ordenación del territorio y el urbanismo, Diputación de Barcelona, Barcelona, 2006.

CORTINA, Albert, Nova cultura del territori i ètica del paisatge, Consell Assessor per al Desenvolupament Sostenible, Generalitat de Catalunya, Documents de recerca, 17, Barcelona, 2010.

CUADRADO, Manuel y BERENGUER, Gloria, El Consumo de Servicios Culturales, ESIC, Madrid, 2002.

DÉJEANT-PONS, Maguelonne, "La Convención Europea del Paisaje”, El paisaje y la gestión del territorio. Criterios paisajísticos en la ordenación del territorio y el urbanismo, Diputación de Barcelona, Barcelona, 2006.

DEL POZO, Cristina, "El paisaje como sistema dinámico: una inspiración para la ciudad contemporánea", Ciudad y Territorio, núm. 180, 2014.

DEPARTAMENT DE TERRITORI I SOSTENIBILITAT, Criteris per a la correcta integració en el paisatge de les construccions aïllades en sòl no urbanitzable, Generalitat de Catalunya, Barcelona, 2013.

DEPARTAMENTO DE MEDIO AMBIENTE, PLANIFICACIÓN TERRITORIAL Y VIVIENDA, Guía para la elaboración de estudios de integración paisajística en la Comunidad Autónoma del País Vasco, Tecnalia, Vitoria-Gasteiz, 2016.

DOMĖNECH, Martí, "Consideraciones sobre el futuro marco jurídico para la ordenación del paisaje", El paisaje y la gestión del territorio. Criterios paisajísticos en la ordenación del territorio y el urbanismo, Diputación de Barcelona, Barcelona, 2006.

FABEIRO MOSQUERA, Antonio, "La protección del paisaje: su creciente importancia en el ámbito internacional y la dispersión de instrumentos jurídicos para su protección integral en el Derecho español”, Revista Española de Derecho Administrativo, núm. 131, 2006. 
FERNÁNDEZ LATORRE, Francisco M., "Análisis legislativo y jurisprudencial en materia de paisaje y turismo. Implicaciones prácticas", Medio ambiente y derecho. Revista electrónica de derecho ambiental, núm. 20, 2010.

FERNÁNDEZ RODRÍGUEZ, Carmen, La protección del paisaje. Un estudio de Derecho español y comparado, Marcial Pons, Madrid, 2007.

FERNÁNDEZ RODRÍGUEZ, Carmen, Estética y paisaje urbano, La Ley, Madrid, 2011.

FERNÁNDEZ RODRÍGUEZ, Carmen, "Algunas consideraciones sobre el actual panorama del paisaje urbano en nuestro ordenamiento: Desde su originaria y exclusiva protección por el ordenamiento urbanístico al incipiente ordenamiento paisajístico", Revista de Derecho Urbanístico y Medio Ambiente, núm. 277, 2012.

FERNÁNDEZ RODRÍGUEZ, Carmen, "El estreno de nuestro Derecho en la ordenación paisajística: a propósito de la ordenación y protección del paisaje en la legislación valenciana", Revista de Administración Pública, núm. 172, 2007.

FERNÁNDEZ SALINAS, Víctor, "Los paisajes culturales: Aspectos generales y una mirada desde España”, Álvarez Areces, Miguel Ángel, Paisajes Culturales. Patrimonio Industrial y Desarrollo Regional, INCUNA, Gijón, 2012.

FERRER AIXALÀ, Amador, "Paisajes urbanos", Busquets, Jaume y Cortina, Albert, Gestión del paisaje, Ariel, Barcelona, 2009.

FROLOVA, Marina, "La evolución reciente de las políticas de paisaje en España y el convenio europeo del paisaje", Proyección, núm. 6, 2009.

GARCÍA RUBIO, Fernando, "Régimen jurídico de la publicidad exterior", Nuevos retos sectoriales del urbanismo, El consultor de los Ayuntamientos y de los juzgados, La Ley-Wolters Kluwer, 2009.

GARCÍA RUBIO, Fernando, "Régimen jurídico particular del paisaje urbano. Entre las determinaciones de adaptación al ambiente, las normas sectoriales y la regulación de la estética en el ámbito de la autonomía local", Gifreu Font, Judith, Bassols Coma, Martín y Menéndez Rexach, Ángel (dirs.), El derecho de la ciudad y el territorio. Estudios en homenaje a Manuel Ballbé Prunés, INAP, Madrid, 2016. 
GIFREU FONT, Judith, L'ordenació urbanística a Catalunya, Marcial Pons, Madrid, 2012.

GONZÁLEZ-VARAS, Ignacio, Patrimonio cultural. Conceptos, debates y problemas, Cátedra, Madrid, 2015.

HERVÁS MAS, Jorge, Ordenación del territorio, urbanismo y protección del paisaje, Dykinson, Madrid, 2009.

HILLEGERS, Saskia y LAM, Tycho, "National Report: the Netherlands", XI International Urban Law Congress, Architectural Heritage, Sites and Landscapes Seized by Urban Law, Barcelona, septiembre de 2017.

IGLESIAS LUCÍA, Montserrat, "Les competències locals en matèria de protecció, gestió i ordenació del paisatge”, Casado Casado, Lucía y Fuentes Gasó, Josep Ramón (dirs.), Dret ambiental local de Catalunya, Tirant lo Blanch, Valencia, 2017.

LASAGABASTER HERRARTE, Iñaki y LAZCANO BROTONS, Íñigo, "El régimen jurídico de la protección del paisaje”, Lasagabaster Herrarte, Iñaki (dir.), Derecho Ambiental. Parte Especial I. Espacios Naturales, Flora y Fauna, Montes, Paisaje, LETE, Pamplona-Bilbao, 2007.

LOZANO CUTANDA, Blanca, "STC 53/2017, sobre la Ley de Evaluación Ambiental: se mantiene el esquema procedimental común y se anulan o reinterpretan algunos preceptos", Actualidad Jurídica Ambiental, núm. 71, 2017. LÓPEZ RAMÓN, Fernando, "Reflexiones sobre la indeterminación y amplitud del patrimonio cultural”, Revista Aragonesa de Administración Pública, núm. 15, 1999.

LÓPEZ RAMÓN, Fernando, "La Ley de Conservación de 1989 y la continuidad de sus planteamientos en la Ley del Patrimonio Natural de 2007", Noticias de la Unión Europea, núm. 307, 2010 (Ejemplar dedicado a: Patrimonio natural y biodiversidad).

LÓPEZ RAMÓN, Fernando, La conservación de la naturaleza: los espacios naturales protegidos, Publicaciones del Real Colegio de España, Bolonia, 1980. LÓPEZ RAMÓN, Fernando, "Régimen jurídico de los Parques Nacionales", Machado, Antonio (ed.), Los parques nacionales. Aspectos jurídicos y administrativos, MAPA, Madrid, 1988. 
MANERO MIGUEL, Fernando y GARCÍA CUESTA, José Luis (coords.), Patrimonio cultural y desarrollo territorial, Thomson Reuters Aranzadi, Cizur Menor, 2016.

MANITO, Félix, Planificación estratégica de la cultura en España, Iberautor Promociones Culturales, Barcelona, 2008.

MATA OLMO, Rafael, "Convenio europeo del paisaje del Consejo de Europa. Notas sobre su aplicación en España”, Patrimonio cultural y derecho, núm. 18, 2014.

MÓNIZ SÁNCHEZ, Carmen, "El ámbito municipal como marco territorial básico para la gestión y la participación en las políticas paisajísticas", Paisaje y ordenación del territorio, Junta de Andalucía, Consejería de Obras Públicas y Transporte - Fundación Duques de Soria, Sevilla, 2002.

MOYA PELLITERO, Ana María, La percepción del Paisaje Urbano, Biblioteca Nueva, 2011.

MULERO MENDIGORRI, Alfonso, "Significado y tratamiento del paisaje en las políticas de protección de espacios naturales de España", Boletín de la Asociación de Geógrafos Españoles, núm. 62, 2013.

MUÑOZ CRIADO, Arancha (dir.), Guía metodológica. Estudios de paisaje, Conselleria de Infraestructuras, Territorio y Medio Ambiente, 2012.

PAREJA LOZANO, Carles, "Instrumentos legales para la ordenación del paisaje", El paisaje y la gestión del territorio. Criterios paisajísticos en la ordenación del territorio y el urbanismo, Diputación de Barcelona, Barcelona, 2006.

PÉREZ GONZÁLEZ, Carlos, "Relaciones entre la ordenación urbanística y la protección del paisaje", Revista de Derecho Urbanístico y Medio Ambiente, núm. 243, 2008.

PIETX, Jordi y BASORA, Xavier, "La custòdia del territori: un nou instrument de concertació basat en la implicació ciutadana per a conservar el paisatge", Observatori del Paisatge, Ordenació i gestió del paisatge a Europa, Plecs de Paisatge Eines, 2, Observatori del Paisatge, Olot, 2009.

PIZZIOLO, Giorgio, "Experiencia europea de valoración social del paisaje", Paisaje y ordenación del territorio, Junta de Andalucía, Consejería de Obras Públicas y Transporte - Fundación Duques de Soria, Sevilla, 2002. 
PRIEUR, Michel, "La Convención Europea del Paisaje", Administración de Andalucía. Revista Andaluza de Administración Pública, núm. 50, 2003.

PRIORE, Riccardo, "Derecho al paisaje, derecho del paisaje", Paisaje y ordenación del territorio, Junta de Andalucía, Consejería de Obras Públicas y Transporte - Fundación Duques de Soria, Sevilla, 2002.

ROSELLÓ CEREZUELA, David, Diseño y evaluación de proyectos culturales, Ariel, Barcelona, 2004.

SABALZA HERNÁEZ, Alain, La consagración jurídica del paisaje a través del Convenio Europeo del Paisaje, IVAP, Oñati, 2008.

SÁMANO BUENO, Pablo, "La arquitectura: un arte asediado por el derecho urbanístico", Revista de Derecho Urbanístico y Medio Ambiente, núm. 243, 2008.

SÁNCHEZ GOYANES, Enrique, "Técnicas urbanísticas de protección del patrimonio cultural en el Derecho español", Revista Urbs.net 3, febrero-marzo de 2001.

SÁNCHEZ SÁEZ, Antonio José, "La indemnización de los daños ocasionados en el paisaje como consecuencia de expropiaciones forzosas y de la ejecución de obras públicas", Revista de Administración Pública, núm. 189, 2012.

SANZ HERRÁIZ, Concepción, "El paisaje como recurso", Martínez de Pisón, Eduardo (dir.), Estudios sobre el paisaje, UAM - Fundación Duques de Soria, Murcia, 2000.

SANZ HERRÁIZ, Concepción, "Paisaje y patrimonio natural y cultural: historia y retos actuales”, Nimbus, núm. 29-30, 2012.

STELLA RICHTER, Paolo y PARISIO, Vera, "Italie", XI International Urban Law Congress, Architectural Heritage, Sites and Landscapes Seized by Urban Law, Barcelona, septiembre de 2017.

VACCARO, Ismael y BELTRAN, Oriol, "Turning nature into collective heritage: The social framework of the process of patrimonialization of nature", Roigé, Xavier y Frigolé, Joan (eds.), Constructing cultural and natural heritage. Parks, Museums and Rural Heritage, ICRPC, Girona, 2010.

VADRÍ I FORTUNY, Maria Teresa, "Política ambiental de Cataluña", López Ramón, Fernando (coord.), Observatorio de Políticas Ambientales 1978-2006, Thomson-Aranzadi, Cizur Menor, 2006. 
VELASCO MAÍLLO, Honorio Manuel, "Patrimonio Cultural Inmaterial", Antigüedad del Castillo-Olivares, María Dolores (dir.), Mediación y gestión del patrimonio en Europa, Editorial Universitaria Ramón Areces, Madrid, 2012.

VENEGAS MORENO, Carmen y RODRÍGUEZ RODRÍGUEZ, Jesús, "Valoración de los paisajes monumentales. Una propuesta metodológica para la integración paisajística de los conjuntos históricos”, Zoido, Florencio (coord.), Paisaje y Ordenación del Territorio, Junta de Andalucía - Fundación Duques de Soria, Sevilla, 2002.

ZOIDO NARANJO, Florencio, "El paisaje, ideas para la actuación”, Martínez de Pisón, Eduardo (dir.), Estudios sobre el paisaje, UAM - Fundación Duques de Soria, Murcia, 2000.

ZOIDO NARANJO, Florencio, "Principales retos de adaptación de la Convención Europea del Paisaje a las políticas de ordenación del territorio en Europa", El paisaje y la gestión del territorio. Criterios paisajísticos en la ordenación del territorio y el urbanismo, Diputación de Barcelona, Barcelona, 2006.

ZUBELZU MíNGUEZ, Sergio y ALLENDE ÁLVAREZ, Fernando, "El concepto de paisaje y sus elementos constituyentes: requisitos para la adecuada gestión del recurso y adaptación de los instrumentos legales en España", Cuadernos de Geografía, vol. 24, núm. 1, 2015. 